Florida International University FIU Digital Commons

FIU Electronic Theses and Dissertations

University Graduate School

$3-5-2012$

\title{
Black Band Disease: Elucidating Origins and Disease Mechanisms
}

Aaron Miller

Florida International University, aaron.miller@fiu.edu

DOI: $10.25148 /$ etd.FI12041109

Follow this and additional works at: https://digitalcommons.fiu.edu/etd

\section{Recommended Citation}

Miller, Aaron, "Black Band Disease: Elucidating Origins and Disease Mechanisms" (2012). FIU Electronic Theses and Dissertations. 558. https://digitalcommons.fiu.edu/etd/558

This work is brought to you for free and open access by the University Graduate School at FIU Digital Commons. It has been accepted for inclusion in FIU Electronic Theses and Dissertations by an authorized administrator of FIU Digital Commons. For more information, please contact dcc@fiu.edu. 


\title{
FLORIDA INTERNATIONAL UNIVERSITY
}

\author{
Miami, Florida
}

\section{BLACK BAND DISEASE: ELUCIDATING ORIGINS AND DISEASE MECHANISMS}

\author{
A dissertation submitted in partial fulfillment of the \\ requirements for the degree of \\ DOCTOR OF PHILOSOPHY \\ in \\ BIOLOGY \\ by
}

Aaron W. Miller

2012 
To: Dean Kenneth Furton

College of Arts and Sciences

This dissertation, written by Aaron W. Miller, and entitled Black Band Disease:

Elucidating the Origins and Disease Mechanisms, having been approved in respect to style and intellectual content, is referred to you for judgment.

We have read this dissertation and recommend that it be approved.

Walter Goldberg

Patricia Blackwelder

$\begin{array}{r}\hline \text { DeEtta Mills } \\ \hline \text { Joseph Boyer } \\ \hline \text { Laurie Richardson, Major Professor }\end{array}$

Date of Defense: March 5, 2012

The dissertation of Aaron W. Miller is approved.

$\begin{array}{r}\text { Dean Kenneth Furton } \\ \text { College of Arts and Sciences } \\ \hline \begin{array}{r}\text { Dean Lakshmi N. Reddi } \\ \text { University Graduate School }\end{array}\end{array}$

Florida International University, 2012 


\section{DEDICATION}

This dissertation is dedicated to my parents, and my life partner Deana Sritalapat. They have helped to guide my intellectual development throughout my life, and have always encouraged me to follow my aspirations. 


\section{ACKNOWLEDGMENTS}

I would like to thank my major advisor, Dr. Laurie L. Richardson, for providing me with the opportunity in receiving a Ph.D. degree and in the support she has provided. Through her guidance, I have been able to grow as a scientist and biologist, and to progress as a scientific writer in ways I would not have without her. Dr. Patricia Blackwelder and Husain Al-Sayegh provided an immense amount of help and guidance with electron microscopy. Drs. DeEtta Mills, Walter Goldberg, and Joseph Boyer guided me through my dissertation, and helped to direct my research, as well as taught me techniques vital to biological research. Dr. Miroslav Gantar and Dr. Longin Kaczmarsky also provided help with numerous aspects of my research, and in helping me to become a better scientist. Dr. Raju Sekar mentored me, and helped to guide my research as a post-doc in Dr. Richardson's lab. Drs. Joshua Voss and Sarah Edge provided me the opportunity to help in their research at Lee Stocking Island, Bahamas, and provided me with some samples vital for my research. Kristin Kuehl, Beth Zimmer, Jamie Myers, Zoe Pratte, Dina Stanić, Abigael Brownell, and Emily Broderick were/are graduate students in Dr. Richardson's lab who provided an enormous amount of research assistance, and moral support throughout my degree. I would also like to acknowledge several undergraduate students also aided in my research including Mike Roig, Steven Diaz, and Jorge Ahues. The Dissertation Year Fellowship (DYF), which was provided by Florida International University (FIU), granted me a year's salary to focus on writing my dissertation. 


\section{ABSTRACT OF THE DISSERTATION \\ BLACK BAND DISEASE: \\ ELUCIDATING ORIGINS AND DISEASE MECHANISMS}

by

Aaron W. Miller

Florida International University, 2012

Miami, Florida

Professor Laurie Richardson, Major Professor

Coral diseases were unknown in the scientific community fifty years ago. Since the discovery of a coral disease in 1965, there has been an exponential increase in the number of known coral diseases, as the abundance, prevalence, distribution, and number of host species affected has also significantly increased. Coral diseases are recognized as contributing significantly to the dramatic losses of coral cover on a global basis, particularly in the Caribbean. The apparent sudden emergence of coral diseases suggests that they may be a symptom of an overall trend associated with changing environmental conditions. However, not much evidence has been gathered to address this question. The following studies were designed to build a comprehensive argument to support this hypothesis for one important coral disease - black band disease (BBD).

A meta-analysis of clone libraries identifying the microbial communities associated with BBD reveal important information including that a single cyanobacterial operational taxonomic unit (OTU) was by far the most prevalent OTU in diseased samples, and that the alphaproteobacteria, which include some 
of the most common bacteria in marine waters, were the most diversely represented. The analysis also showed that samples exhibited regional similarities. An fine and ultrastructural characterization of the disease revealed that the cyanobacteria are prolific borers through the coral skeleton, and that the cyanobacteria penetrate coral tissue, leading to their presence ahead of the main migrating disease band. It was further found that apparently healthy corals exposed to toxins found in BBD, exhibited similar tissue degradation to those infected with BBD. Comparing the disease progression to biofilm formation, it was determined that scouting cyanobacteria may contribute to the migration of the disease through progressive biofilm development over intact coral tissue.

Together, these studies provide significant evidence for the hypothesis that BBD is an opportunistic disease, caused by common environmental bacteria, facilitated by the changing environmental conditions associated with climate change. 


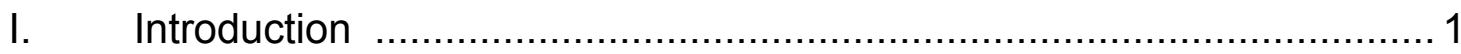

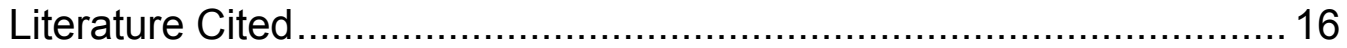

II. A Meta-analysis of 16s rRNA Gene Clone Libraries From the Polymicrobial Black Band Disease of Corals.................................... 23

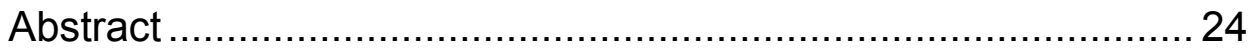

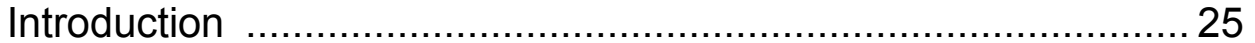

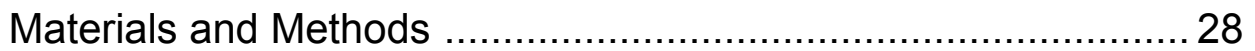

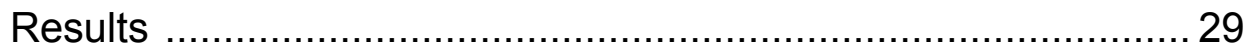

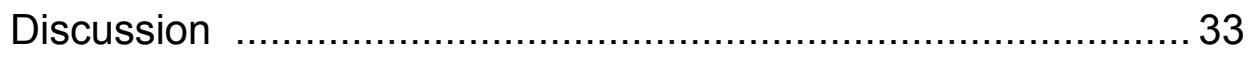

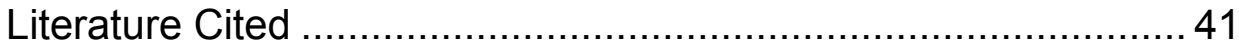

III. Fine-Structural Analysis of Black Band Disease Infected Coral Reveals Boring Cyanobacteria and Novel Bacteria............................ 54

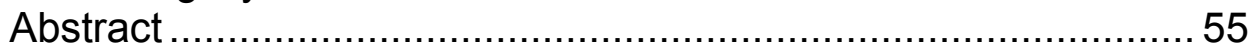

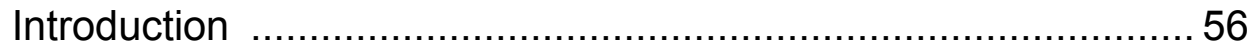

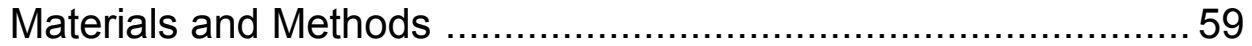

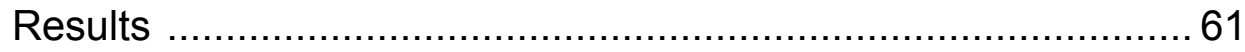

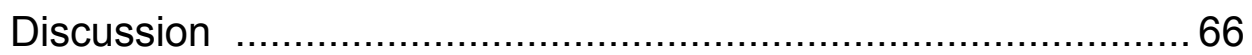

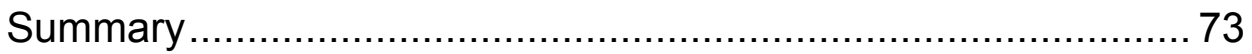

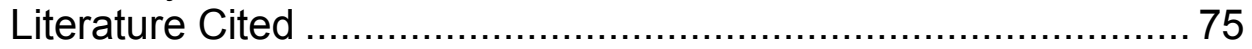

IV. Fine-Structure Analysis of Black Band Disease-Infected Coral and Coral Exposed to the BBD Toxins Microcystin and Sulfide ........... 89

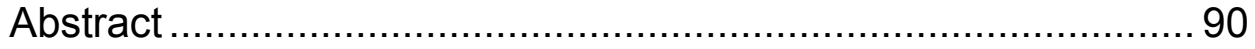

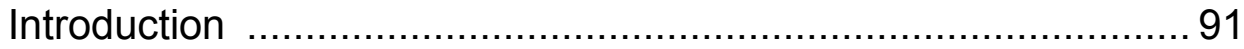

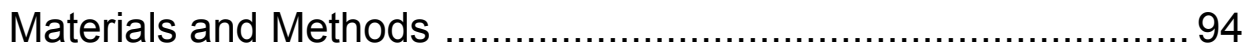

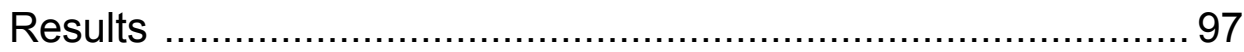

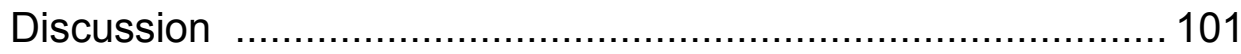

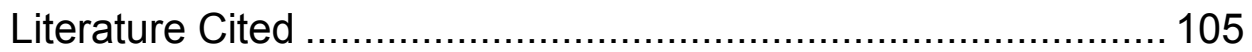

V. Insights into Migration and Development of Coral Black Band

Disease Revealed by Fine Structure Analysis.................................. 118

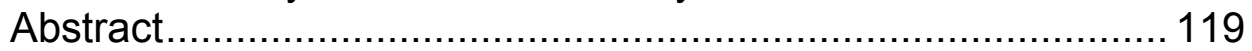

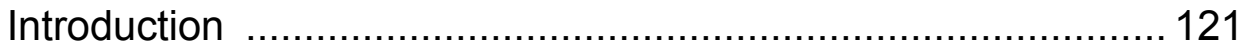

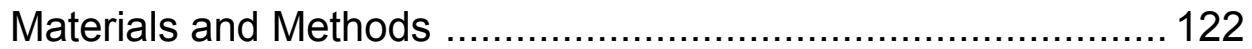

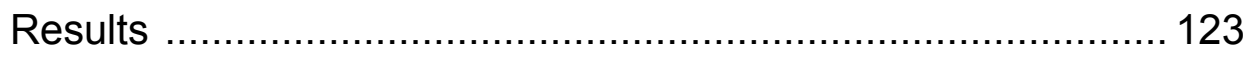

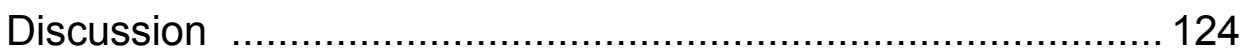

Literature Cited ........................................................... 130 
VII. A Climate-Driven Model for the Infection Cycle of Black Band

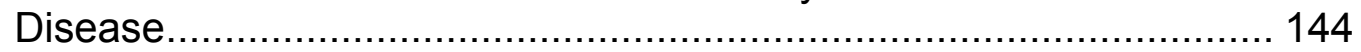

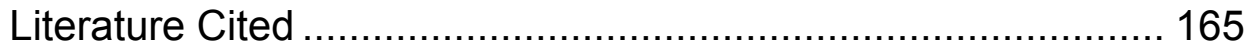

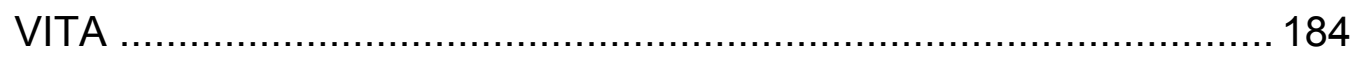


FIGURE

CHAPTER II

Figure 1. Number of OTUs appearing in multiple BBD samples, arranged by taxonomic group.

Figure 2. Number of OTUs appearing in a single BBD sample, arranged by taxonomic group.

Figure 3. NMDS plot exhibiting similarities between BBD composition and host coral species

Figure 4. NMDS plot exhibiting similarities between BBD composition and geographic region

\section{CHAPTER III}

Figure $1 \mathrm{~A}-\mathrm{D}$. The leading edge of a BBD mat, exhibiting cyanobacterial boring, migration, and latitudinal/longitudinal sections of cyanobacteria.

Figure 2 A-D. The leading edge of a BBD mat, exhibiting penetration into coral tissue by cyanobacteria, and other filamentous micoorganisms.

Figure 3 A-D. The interface between the BBD mat and coral tissue, exhibiting tissue degradation, and the presence of clusters of cyanobacteria ahead of the established mat

Figure 4 A-D. Established BBD mat, exhibiting clusters of cyanobacteria, coral tissue remnants, and dividing zooxanthellae.

Figure 5 A-D. The back of the BBD mat, exhibiting loose zooxanthellae, exposed skeleton, and non-cyanobacterial microbial communities.

Figure 6 A-D. Exposed coral skeleton, exhibiting a significant number of bore holes, and from uninfected corals

\section{CHAPTER IV}

Figure 1. Average tissue degradation from corals exposed to BBD toxins or infected with BBD. 
Figure 2 A-D. Corals not exposed to toxins or BBD infection, and those

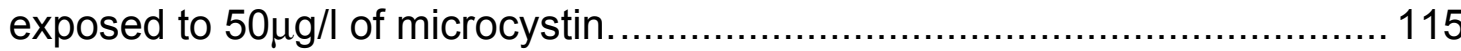

Figure 3 A-D. Corals exposed to $100 \mu \mathrm{g} / \mathrm{l}$ of microcystin, sulfide, or a combination of toxins.

Figure 4 A-F. Corals infected with BBD, or showing degraded zooxanthellae from coral exposed to a combination of toxins.

\section{CHAPTER V}

Figure 1. Cyanobacterium ahead of a BBD mat penetrating through the mesoglea..

Figure 2. Cluster of cyanobacteria ahead of the mature black band exhibiting random orientation.

Figure 3. Cluster of cyanobacteria ahead of the mature black band exhibiting parallel orientation with active EPS secretion.

Figure 4. Cyanobacteria embedded in coral tissue with no associated EPS.

Figure 5. Cyanobacteria embedded in coral tissue with associated EPS

Figure 6. Cluster of cyanobacteria ahead of the migrating band exhibiting coaggregation, and parallel orientation.

Figure 7. Layering of parallel cyanobacterial filaments ahead of the mature band.

Figure 8. Cross-section of parallel cyanobacterial filaments fully embedded in an EPS layer. 143

\section{CHAPTER VI.}

Figure 1. Outline of segments of the BBD infection model

Figure 2. Segment 1 of the BBD infection model Drivers of coral disease 
Figure 3. Segment 2 of the BBD infection model - Resevoirs of BBD

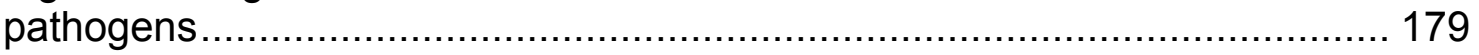

Figure 4. Segment 3 of the BBD infection model - Pathogenesis ................ 180

Figure 5. Segment 4 of the BBD infection model - Biofilm formation ........... 181

Figure 6. Segment 5 of the BBD infection model - Pathobiology ................. 182

Figure 7. Segment 7 of theBBD infection model -

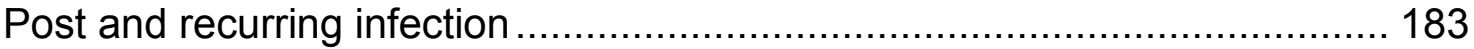


CHAPTER I

INTRODUCTION 
Latest estimates suggest that coral reefs occupy an area of $225,000 \mathrm{~km}^{2}$ of the ocean, covering only $\sim 0.06 \%$ of the total surface area (Spalding and Grenfell 1997). However, reefs may contain as many as $33 \%$ of all marine species (Reaka-Kudla, 1997). Half a billion people depend on coral reefs for some or all of their livelihoods, including food and economic support through fishing, tourism, and other activities (Wilkinson 2008). The loss of coral reef ecosystems would mean the displacement of many people, as well as an increased burden on other fragile ecosystems such as mangrove forests, and seagrass beds.

Coral reefs are especially vulnerable to anthropogenic impacts, specifically eutrophication and elevated temperatures associated with the influx of carbon dioxide into the atmosphere. Corals typically live in oligotrophic waters (Odum and Odum 1955), within a narrow thermal range. Water temperatures that exceed their thermal tolerance result in lethal events such as bleaching (Fitt et al. 2001, Harvell et al. 2007). Changes in the composition of coral holobiont can also occur (Ritchie 2006). Eutrophication and elevated temperatures can have detrimental effects on corals, and are widespread consequences of anthropogenic activities. Measures of the health of these particularly sensitive and highly connected ecosystems and their response to stressors, offer a valuable model. This information may help in elucidating future repercussions associated with these stressors on other ecosystems.

Evidence of coral disease was unknown in the scientific community until 1965, when skeletal anomalies (SKA) were described (Squires 1965). Since that 
time, the number of described coral diseases has increased exponentially (Sutherland et al. 2004, Sokolow 2009). There are currently at least twenty-one such diseases and syndromes known (Weil 2006). Additionally, there has been a significant increase in the prevalence, host range, and distribution of coral diseases in the last decade, particularly in the Caribbean (Raymundo et al. 2008).

Ten of the 21 known diseases, some of which are known to be associated with biotic causes, have been correlated to elevated temperature events (Sutherland et al. 2004). Eutrophication has also been associated with accelerated rates of processes for several diseases including yellow band disease (YBD), black band disease (BBD), aspergillosis, and others (Bruno et al. 2003, Kuntz et al. 2005, Voss and Richardson 2006). It has been suggested that coral diseases may be caused by opportunistic bacteria in compromised hosts that would otherwise be harmless. However, disease is facilitated by environmental changes (Harvell et al. 1999, 2007, Selig et al. 2006, Lesser et al. 2007).

Many diseases are caused by opportunistic pathogens that are normally associated with healthy organisms in a non-pathogenic mode. When environmental variability occurs (e.g., an influx of nutrients, wetter conditions, or an increase in temperature), the host immune system may become compromised, and accelerated bacterial growth can lead to disease. In fact, over half of the infectious diseases that affect even mildly immune compromised humans are caused by commensal bacteria associated with healthy individuals, 
or are common in the environment (Costerton et al. 1999). Corals exhibit innate immunity, which consists of a suite of general characteristics that can react to non-specific potential pathogens, and are not effected by exposure. These may include physical barriers such as a coral mucus layer and the epiderimis, to the production of antimicrobial compounds, and phagocytic amoebocytes (Cotran et al. 1999, Mullen et al. 2005, Nissimov et al. 2009). Environmental variations, such as eutrophication and elevated temperatures, can adversely affect the integrity of coral cells or processes that contribute to its innate immunity (such as mucus production). A shift in environmental conditions can favor the proliferation of potential pathogens, and lower the coral's ability to inhibit their growth, facilitating infection (Mullen et al. 2005).

Since 1960 , the global average temperature has risen $0.65^{\circ} \mathrm{C}$, with a rise of $0.90^{\circ} \mathrm{C}$ since 1850 (Brohan et al. 2006). The exponential increase in the number of coral diseases corresponds closely to the period of exponentially increasing temperature since 1960 (Sutherland et al. 2004). The association between an increase in global temperatures, and emergence of coral diseases that are correlated with elevated temperature, is consistent with the hypothesis that climate change facilitates the growth of opportunistic pathogens, leading to disease.

There are additional characteristics of this hypothesis. The first, and perhaps most pertinent relative to this hypothesis is the origin of the pathogens themselves. It is expected that the potential pathogens would be normally found 
in association with the coral itself, either in the coral skeleton, tissue, or surface mucus. Potential pathogens may also originate from the immediate vicinity of the coral in the surrounding water column or sediments. In contrast, introduced pathogens may not be present normally, but may cause disease opportunistically if they are introduced into the near environment of the coral. Introduction can be through anthropogenic activities such as agricultural/terrestrial runoff, sewage outflow, or from introduced species.

The role of opportunistic pathogens and whether they are introduced or are present is not a trivial one. The origin of pathogens would affect how diseases should be mitigated to limit their impact on coral reefs, and it also has important implications for emergent diseases elsewhere. For example, Sutherland et al. (2010) found a direct connection between the pathogen, Serratia marcescens, associated with the coral disease white pox (Patterson et al. 2002), and localized sewage outflows, suggesting that the disease could be mitigated by either treating the sewage, or by disposing of it in another manner. However, if potential pathogens are normally found in healthy corals, and are more virulent with elevated temperature, warming ocean waters may facilitate the conversion into a pathogenic state. Thus, climate change itself is implicated, and because of its global scope, will be far more challenging to mitigate. It may require some of the effects of climate change itself be addressed in order to limit the impact of disease. Localized introductions of pathogens are limited to the immediate environment. Elevated temperatures may contribute to coral disease 
through an increase in the virulence of potential pathogens, in addition to inhibiting coral defenses. Therefore, the global impact of climate change means it may also have similar effects on potential pathogens in other environments, further contributing to other emergent diseases in other ecosystems. Understanding the impact of climate change on particularly vulnerable coral reef ecosystems is important as if this change continues in its current trajectory.

Only relatively recently have scientists become aware of the prevalence of coral disease. To date, pathogens have been identified for only a few coral diseases, and less is known about their origins. One of the confounding issues has been that corals are morphologically simple organisms and exhibit limited phenotypic responses to disease (Sunagawa et al. 2009). Disease signs typically include discoloration of tissue areas, typical lesions on the coral surface, lysing of tissue, and growth anomalies, leading to descriptive names such as white band disease, dark spots disease, or skeletal eroding band.

Black band disease is one of the more complex coral diseases known. It is somewhat unique in that it is caused by a distinct polymicrobial mat that grows on the external surface of a coral substrate, and migrates across coral tissue as it lyses it (Antonius 1981, Rützler and Santavy 1983, Rüztler et al. 1983). The presence of a conspicuous biofilm makes the pathogenic agents more obvious than in other coral diseases. The band is composed of different taxa of bacteria interacting to form a cohesive unit that gives rise to the characteristics of the disease. The conspicuous nature of the BBD biofilm, its migration, and its 
polymicrobial nature facilitates comparison with other well-studied biofilms to examine similarities and differences. It is one of a limited number of coral diseases that exhibits a global distribution (Sutherland et al. 2004). Since its discovery, the distribution of BBD follows that of coral disease in general. First discovered in the Caribbean (Antonius 1973), BBD was subsequently reported throughout the Indo-Pacific (Antonius 1985, 1988). The Caribbean has characteristically been considered a hot spot for coral disease, but it is now recognized that diseases in the Indo-Pacific have been increasing as well (Rosenberg and Loya 2004, Weil 2006). While this similar distribution may be coincidental, it may also reflect emerging global trends in the spread of coral disease, making BBD a pertinent model for determining the opportunistic capacity of coral pathogens.

The bacterial community associated with BBD is highly variable across the host species and region, leading to debate over the identity of either a single primary or a consortium of pathogens (Garrett \& Ducklow 1975, Ducklow \& Mitchell 1979 Rützler \& Santavy 1983, Taylor 1983, Cooney et al. 2002, FriasLopez et al. 2002, 2003, 2004, Sekar et al. 2006, 2008, 2009, Sussman et al. 2006, Viehman et al. 2006, Barneah et al. 2007, Myers et al. 2007, Voss et al. 2007, Arotsker et al. 2009 Sato et al. 2009). Using several molecular and ecological techniques, Phormidium corallyticum, a cyanobacterium, was the first reported primary BBD pathogen (Rützler and Santavy 1983). The primary pathogen has since been allocated to a newly described genus, Roseofilum (Casamata et al. in review), which has also been described as Pseudoscillatoria 
coralii (Rasoulouniriana et al. 2009). Several other genera of cyanobacteria have been identified in BBD, including Lyngbya, Leptolyngbya and Geitlerinema. Other potential BBD pathogens have also been proposed, including the sulfideoxidizer Beggiatoa, the sulfate-reducer Desulfovibrio, and several heterotrophic bacteria. The latter group includes members of the Bacteroidetes as well as alphaproteobacteria associated with juvenile oyster disease (Garret and Ducklow 1975, Mitchell and Chet 1975, Cooney et al. 2002, Viehman et al. 2006).

Use of molecular techniques such as 16S rRNA gene-based clone libraries and genetic profiling techniques are effective jn identifying potentially important pathogens associated with coral diseases and variability in infected corals. With molecular techniques, researchers have identified coral pathogens associated with the human intestinal tract, as in the case of white pox (Patterson et al. 2002), and numerous pathogens that are common in the water column or the normal microbiota of corals. Several diseases have been associated with Vibrio pathogens such as white band type-I (WBD-I), bacterial bleaching, yellow blotch, and possibly white plague type-II (WPD-II) (Kushmaro et al. 1996, Ritchie and Smith 1998, Cervino et al. 2004, Sunagawa et al. 2009), which is common to the water column (Thompson et al. 2004). However, even if pathogens associated with coral disease are also commonly found in the water column, or any other source, it does not necessarily mean that the disease-causing pathogens are coming from those sources. Thus, current techniques remain somewhat ambiguous in identifying the origins of the pathogens. 
Many molecular studies of coral diseases are limited in scope in relation to time, geographic distribution, and host species. Because of the highly variable nature of these diseases, conducting comprehensive analyses of molecular studies may help to elucidate some important characteristics about a particular disease that is not obvious within the individual studies. In addition, microscopical evidence can be employed to assess disease processes and the origins of pathogens by examining the interactions between the bacteria and the coral host.

As an example of molecular and microscopical synergies, one study found, with cloning and sequencing, that corals harboring non-pathogenic cyanobacterial patches developed BBD 19\% of the time through successional changes in the microbial community associated with the patches (Sato et al. 2009). Histopathological methods determined that corals exhibiting macroscopic signs of white plague harbored a distinct cyanobacterial community similar to that of BBD, except that the community was present deep within the polyp structure, underneath the disease lesion. The authors described this as atypical BBD (Ainsworth et al. 2007) and supports previously observed patterns of infection. The most likely source of the cyanobacteria deep within the coral polyp is the coral tissue or skeleton.

Corals are animals that do not thermoregulate, and maintain internal temperatures near that of the surrounding seawater. Therefore, potential pathogens that may originate from the coral itself are likewise influenced by the surrounding seawater temperature. So, another important aspect in determining 
the opportunistic role of pathogens associated with climate change is to determine what role elevated temperatures actually play in facilitating disease. Harvell et al. (2002) have suggested that climate warming may facilitate infectious diseases in general by increasing both pathogen virulence and host susceptibility. The relationship between a warming climate and incidence of disease has also been suggested as a mechanism for coral diseases in particular (Selig et al. 2006, Harvell et al. 2007), many of which have been correlated with elevated temperature (Sutherland et al. 2004). Indeed, it has been well established that elevated temperature has a negative effect on coral health, leading to bleaching events (Coffroth et al. 1990; Williams and Bunkley-Williams 1990; Glynn 1991; Hoegh-Guldberg 1999; Douglas 2003). Additionally, disease events have been known to increase after mass bleaching (Harvell et al. 2001, 2007). However, differentiating the effect of elevated temperature on coral host susceptibility and pathogen virulence has been difficult because of the complexity of the coral holobiont, and variability of disease signs/pathogens (Harvell et al. 2007).

Black band disease has been shown to exhibit a seasonal pattern of occurrence on reefs of temperate latitude, with optimal activity at or above $25^{\circ} \mathrm{C}$ (Antonius 1981, 1985, Rützler et al. 1983, Taylor 1983, Edmunds 1991, Bruckner and Bruckner 1997, Kuta and Richardson 2002, Sato et al. 2009). Thus several field surveys have correlated BBD prevalence with elevated temperatures. Elevated temperatures in the summer have also been shown to increase the rate of progression of BBD two-fold in infected corals from the Great Barrier Reef 
(GBR). There was a concurrent increase in the rate of transmission between colonies as well (Boyett et al. 2007). BBD has, however, been reported year round on temperate reefs, at temperatures as low as $20^{\circ} \mathrm{C}$ (Kuta and Richardson 1996). Therefore, prolonged elevated temperatures may have a lasting effect on the coral holobiont, the pathogenic consortium, or both, even after temperatures are reduced. While these studies are important in determining the correlation between elevated temperature and disease prevalence, they do not differentiate between coral host and pathogen virulence effects.

It has been reported that the then agreed upon BBD primary pathogen, Phormidium corallyticum, exhibited a photosynthetic temperature optimum at or above $30^{\circ} \mathrm{C}$ (Richardson and Kuta 2003). In contrast to this, the BBD cyanobacterium described as $P$. coralii exhibited optimal growth at an intermediate temperature of $25^{\circ} \mathrm{C}$, rather than 22 or $30^{\circ} \mathrm{C}$ (Rasoulouniriana et al. 2009). Thus, there is equivocal evidence present to determine the effect of elevated temperature on the virulence of BBD pathogens. However, the differential temperature optima may reflect the growth of unique microbial communities in this highly variable disease. These differences suggest that additional experimental evidence needs to be collected to differentiate the effects of elevated temperature on the susceptibility of corals to BBD, as well as on the virulence of the disease pathogens. Laboratory experiments can be accomplished more effectively with BBD compared to other coral diseases, because of the conspicuous nature of the disease consortium, and ease which 
corals may be artificially infected (Rützler et al. 1983, Voss and Richardson 2006).

It has been reported that biofilms constitute a majority of the bacterial biomass in most ecosystems (Geesy et al. 1977, Costerton et al. 1978, Costerton et al. 1999, Handley et al. 2001, Wolcott and Ehrlich 2008). Furthermore, it is now known that $65-80 \%$ of infectious human diseases are caused by biofilms including cystic fibrosis lung infections, tuberculosis, and even gingivitis (Marsh and Bradshaw 1995, Govan and Deretic 1996, Ojha et al. 2008, Wolcott and Ehrlich 2008).

Black band disease is caused by a stratified, cyanobacterial-dominated mat, similar to those found in hotspring outflows and hypersaline ponds. This is the case not only in terms of the composition of the microbiota, but also in the chemical microenvironment of the mat as well (Carlton and Richardson 1995). BBD differs from these communities in that it is the only cyanobacterial mat known to migrate horizontally across an animal substratum and to kill the animal (coral) as it migrates. The presence of sulfate-reducing and sulfide-oxidizing bacteria in BBD is well known (Chet and Mitchell 1975, Garret and Ducklow 1975, Cooney et al. 2002, Frias-Lopez et al. 2002). These bacteria, together with the photosynthetic BBD cyanobacteria, lead to a dynamic sulfuretum. During the day the surface of the BBD mat is superoxic while the base of the band is anoxic and contains sulfide. At night the band is fully anoxic and a sulfide-rich anoxic zone extends out into the water column (Carlton and Richardson 1995). In BBD, the sulfide-rich, anoxic zone is located directly adjacent to coral tissue. 
The anoxic zone is associated with coral tissue lysis at the concentrations found in BBD in the time it takes to migrate across a fixed point on a coral (Richardson et al. 1997). The development of such stratified polymicrobial, cyanobacteriadominated mats has been suggested to require interspecific quorum sensing (Decho et al. 2010).

In addition to the toxic sulfide produced from BBD sulfate reducing bacteria, the cyanobacteria in BBD also produce toxins. The cyanotoxin microcystin has been found both in freshly collected BBD samples and from cyanobacteria isolated from BBD (Richardson et al. 2007, Gantar et al. 2009, Staniç et al. 2011). The production of microcystin within BBD could be influenced by environmental parameters found in the BBD consortium. For example it has been shown that microcystin production decreases with elevated temperature for some cyanobacteria isolated from BBD (Gantar et al. 2009). This is contrary to what is expected given that BBD processes have been positively correlated with elevated temperatures (Rützler et al. 1983, Edmunds 1991, Kuta \& Richardson 1996, Kuta \& Richardson 2002, Richardson \& Kuta 2003, Boyett et al. 2007). However, in the most prevalent strain found in BBD (Roseofilum) microcystin production was not affected by temperature (Staniç et al. 2011). Microcystin is a known, potent hepatotoxin that disrupts protein phosphatases and is concentrated in the livers of vertebrates (Dittman and Wiegand 2006). Less is known about its effects on invertebrates, but its presence in BBD may contribute to the disease processes such as tissue lysis. 
The studies included in this dissertation cover a range of investigative lines of inquiry which focus on evidence for the origins of the BBD pathogens. In addition, elucidations of mechanisms that contribute to the formation of BBD in corals, as well as the infection process are clarified at the ultrastructural level. These findings are presented in the following five chapters, with a concluding chapter presenting a theoretical model of infection.

Chapter two has been published in the journal FEMS Microbiology Ecology, and presents a meta-analysis of 16S rRNA gene based clone libraries that have been constructed from BBD. The analysis quantifies the most prevalent pathogens associated with BBD at the class/phylum level, as well as at the level of operational taxonomic unit (OTU). It also quantifies the relationship between geographic region and coral host specificity in relation to the disease pathogens.

Chapter three has been published in the journal Diseases of Aquatic Organisms, and is an ultrastructural (EM) characterization of BBD from both naturally and artificially infected corals. This chapter examines the disease mechanisms associated with the disease, and relationships that indicate the origin of the pathogens associated with the disease.

Chapter four has been published in the Journal of Invertebrate Pathology, and presents an ultrastructural comparison of fragments exposed to the toxins microcystin and sulfide (both produced in BBD) and BBD-infected coral fragments. Both qualitative and quantitative data were collected to compare the fragments in determination of the role toxins have in the disease process. 
Chapter five provides insights into the migration of the mature BBD mat across a coral substrate, and compares the development of other well studied biofilm diseases such as those associated with Pseudomonas aeruginosa lung infections and dental plaque in order to determine the similarities and the differences between these systems.

Chapter six provides a comprehensive model for the infection cycle of $\mathrm{BBD}$, synthesizing the data collected from research on $\mathrm{BBD}$, including the data presented in previous chapters of this dissertation.

These studies elucidate mechanisms that contribute to the initiation and progression of black band disease in a rapidly changing environment. In the concluding chapter, a model for the BBD infection process is presented using all known available data on BBD, and includes the studies conducted in this dissertation. 


\section{References}

Ainsworth TD, Kramasky-Winter E, Loya Y, Hoegh-Guldberg O, and Fine M (2007). Coral disease diagnostics: What's the difference between a plague and a band? Appl and Envir Microbiol 73(3): 981-992.

Antonius A (1973). New observations on coral destruction in reefs. 10th Meet Assoc IsI Mar Lab Carib 10:3.

Antonius A (1981). The "band" diseases in coral reefs. Proc $4^{\text {th }}$ Int Coral Reef Symp 7-14.

Antonius A (1985). Coral diseases in the Indo-Pacific: A first record. Mar Eco 6(3):197-218.

Antonius A (1988). Distribution and dynamics of coral diseases in the eastern Red Sea. Proc $6^{\text {th }}$ Int Coral Reef Symp 3: 145-150.

Arotsker L, Siboni N, Ben-Dov E, Kramasky-Winter E, Loya Y, Kushmaro A (2009). Vibrio sp. as a potentially important member of the black band disease consortium in Favia sp. corals. FEMS Microbio Eco 70:3 515-524.

Barneah O, Ben-Dov E, Kramarsky-Winter E, Kushmaro A (2007).

Characterization of black band disease in Red Sea stony corals. Environ Microbiol 9: 1995-2006.

Boyett HV, Bourne DG, Willis BL (2007). Elevated temperature and light enhance the progression and spread of black band disease on staghorn corals of the great barrier reef. Mar Biol 151: 1711-1720.

Brohan P, Kennedy JJ, Harris I, Tett SFB, Jones PD (2006). Uncertainty estimates in regional and global temperature changes: a new data set from 1850. J of Geophys Res 111 p. D21206 10.1029/2005JD006548.

Bruckner A, Bruckner R (1997). The persistence of black band disease in Jamaica: Impact on community structure. Proc $8^{\text {th }}$ Int Coral Reef Symp 1: 601-606.

Bruno JF, Petes LE, Harvell CD, Hettinger A (2003). Nutrient enrichment can increase the severity of coral diseases. Eco Lett 6:1056-1061.

Carlton RG, Richardson LL (1995). Oxygen and sulfide dynamics in a horizontally migrating cyanobacterial mat: black band disease of corals. FEMS Microbio Eco 18: 155-162. 
Cervino JM, Hayes RL, Goreau TJ, Smith GW (2004). Zooxanthellae regulation in yellow blotch/band and other coral diseases contrasted with temperature related bleaching: in situ destruction vs. expulsion. Symbiosis 37: 63-85.

Coffroth MA, Lasker HR, Oliver JK (1990). Coral mortality outside of the eastern Pacific during 1982-1983: relationship to El Niño. In: Glynn PW (ed) Global ecological consequences of the 1982-83 El Niño-Southern Oscillation. Elsevier.

Cooney RP, Pantos O, Le Tissier MDA, Barer MR, O'Donnell AG and Bythell JC (2002). Characterization of the bacterial consortium associated with black band disease in coral using molecular microbiological techniques. Environ Microbiol 4: 401-413.

Costerton JW, Geesey GG, Cheng K-J (1978). How bacteria stick. Sci Am 238: 86-95.

Costerton JW, Stewart PS, Greenberg EP (1999). Bacterial biofilms: a common cause of persistent infections. Science 284: 1318-1322.

Cotran RS, Kumar V, Collins T (1999). Robbins pathologic basis of disease. 6th edn. Saunders, Philadelphia.

Decho AW, Norman RS, Visscher PT (2010). Quorum sensing in natural environments: emerging views from microbial mats. Trends in Microbio. 18(2): 73-80.

Dittmann E, Wiegand C (2006). Cyanobacterial toxins-occurrence, biosynthesis and impact on human affairs. Mol Nutr Food Res 50: 7-17.

Douglas AE (2003). Coral bleaching - how and why? Mar Pol Bull 46(4): 385392.

Ducklow HW, Mitchell R (1979). Observations on naturally and artificially diseased tropical corals: A scanning electron microscope study. Microb Ecol 5: 215-223.

Edmunds PJ (1991). Extent and effect of black band disease on a Caribbean reef. Coral Reefs 10(3): 161-165.

Fitt WK, Brown BE, Warner ME, Dunne RP (2001). Coral bleaching: interpretation of thermal tolerance limits and thermal thresholds in corals. Coral Reefs 20(1): 51-65. 
Frias-Lopez JA, Zerkle L, Bonheyo GT, Fouke BW (2002). Partitioning of bacterial communities between seawater and healthy, black band diseased, and dead coral surfaces. Appl Environ Microbiol 68: 2214-2228.

Frias-Lopez JA, Bonheyo GT, Jin QS, Fouke BW (2003). Cyanobacteria associated with coral black band disease in Caribbean and Indo-Pacific reefs. Appl Environ Microbiol 69: 2409-2413.

Frias-Lopez JA, Klaus JS, Bonheyo GT, Fouke BW (2004). Bacterial community associated with black band disease in corals. Appl Environ Microbiol 70:5955-5962.

Gantar M, Sekar R, Richardson LL (2009). Cyanotoxins from black band disease of corals and from other coral reef environments. Microb Ecol 58: 856-864.

Garrett P, Ducklow H (1975). Coral disease in Bermuda. Nature 253: 349350.

Geesey GG, Richardson WT, Yeomans HG, Irvin RT, Costerton JW (1977). Microscopic examination of natural sessile bacterial populations from an alpine stream. Can J Microbiol 23(12):1733-36.

Glynn PW (1991). Coral reef bleaching in the 1980's and possible connections with global warming. Trends in Eco and Evol 6(6): 175-179.

Govan JR, Deretic V (1996). Microbial pathogenesis in cystic fibrosis: mucoid Pseudomonas aeruginosa and Burkholdia cepacia. Microbio and Molec Bio Rev 60(3): 539-574.

Handley PS, Rickard AH, High NJ, Leach SA (2001). Coaggregation- is it a universal biofilm phenomenon? Biofilm Community Interactions: Chances or Necessity? Bioline Press, Cardiff, UK.

Harvell CD, Kim K, Burkholder JM, Colwell RR, Epstein PR, Grimes DJ, Hofmann EE, Lipp EK, Osterhaus AD, Overstreet RM, Porter JW, Smith GW, Vasta GR (1999). Emerging marine diseases - climate links and anthropogenic factors. Science 285: 1505-1510.

Harvell CD, Kim K, Quirolo C, Weir J, Smith GW (2001). Coral bleaching and disease: Contributors to 1998 mass mortality in Briareum asbestinum (Octocorallia, Gorgonacea). Hydrobiol 460: 97-104. 
Harvell CD, Mitchell CE, Ward JR, Altizer S, Dobson AP, Ostfeld RS, Samuel MD (2002). Climate warming and disease risks for terrestrial and marine biota. Science 296(5576): 2158-2162.

Harvell CD, Jordán-Dahlgren E, Merkel S, Rosenberg E, Raymundo L, Smith GW, Weil E, Willis B (2007). Coral disease, environmental drivers, and the balance between coral and microbial associates. Oceano 20(1): 172195.

Hoegh-Guldberg $O$ (1999). Climate change, coral bleaching and the future of the world's coral reefs. Mar Freshwater Res 50: 839-866.

Kuntz NM, Kline DI, Sandin SA, Rohwer F (2005). Pathologies and mortality rates caused by organic carbon and nutrient stressors in three Caribbean coral species. Mar Eco Prog Ser 294: 173-180.

Kushmaro A, Loya Y, Fine M, Rosenberg E (1996). Bacterial infection and coral bleaching. Nature 380(6573): 396.

Kuta KG, Richardson LL (1996). Abundance and distribution of black band disease on coral reefs in the northern Florida Keys. Coral Reefs 15: 219223.

Kuta KG, Richardson LL (2002). Ecological aspects of black band disease of corals: relationships between disease incidence and environmental factors. Coral Reefs 21: 393-398.

Lesser MP, Bythell JC, Gates RD, Johnstone RW, Hoegh-Guldberg O (2007). Are infectious diseases really killing corals? Alternative explanations of the experimental and ecological data. J of Exp Mar Bio and Eco 346(1-2): 3544.

Marsh PD, Bradshaw DJ (1995). Dental plaque as a biofilm. J of Indust Microbio and Biotech 15(3): 169-175.

Mitchell R and Chet I (1975). Bacterial attack of corals in polluted seawater. Microb Ecol 2: 227-233.

Mullen KM, Peters EC, Harvell CD (2005). Coral resistance to disease. Pp. 377399 in Coral Health and Disease. E. Rosenberg and Y. Loya, eds, Springer- Verlag.

Myers JL, Sekar R, Richardson LL (2007). Molecular detection and ecological significance of the cyanobacteria Geitlerinema and Leptolyngbya in black band disease of corals. Appl Environ Microbiol 73: 5173-5182. 
Nissimov J, Rosenberg E, Munn CB (2009). Antimicrobial properties of resident coral mucus bacteria of Oculina patagonica. FEMS Microbiol Lett 292: 210-215.

Odum HT, Odum EP (1955). Trophic structure and productivity of a windward coral reef community on Eniwetok Atoll. Ecolog Mongr 25(3): 291-320.

Patterson KL, Porter JW, Ritchie KB, Polson SW, Mueller E, Peters EC, Santavy DL, Smith GW (2002). The etiology of white pox a lethal disease of the Caribbean elkhorn coral Acropora palmata. Proc Natl Acad Sci USA 99:8725-8730.

Rasoulouniriana D, Siboni N, Ben-Dov E, Kramarsky-Winter E, Loya Y, Kushmaro A (2009). Pseudoscillatoria coralii gen. nov., sp. nov., a cyanobacterium associated with coral black band disease. Dis of Aquat Org 87: 91-96.

Raymundo LJ, Couch CS, Bruckner AW, Harvell CD, Work TM, Weil E, Woodley CM, Jordan-Dahlgren E, Willis BL, Sato Y, Aeby GS (2008). Coral disease handbook: guidelines for assessment, managing, and monitoring. Coral reef targeted research and capacity building for management program.

Reaka-Kudla ML (1997). The global biodiversity of coral reefs: a comparison with rain forests. p. 83-122. In ML Reaka-Kudla, DE Wilson, EO Wilson (ed.) Biodiversity II. Joseph Henry Press, Washington.

Richardson LL, Kuta KG, Schnell S, Carlton R (1997). Ecology of the black band disease microbial consortium. Proc 8th Int Coral Reef Symp 1: 597-600.

Richardson LL, Kuta KG (2003). Ecological physiology of the black band cyanobacterium Phormidium corallyticum. FEMS Microbiol Eco 43: 287298.

Richardson LL, Sekar R, Myers J, Gantar M, Voss J, Kaczmarsky L, Remily E, Boyer G, Zimba P (2007). The presence of the cyanobacterial toxin microcystin in black band disease of corals. FEMS Microbio Eco 272(2): 182-187.

Ritchie KB, Smith GW (1998). Type II white band disease. Rev de Biol Trop 46(5): 199-203.

Rosenberg E, Loya Y (2004). Coral Health and Disease. Springer, Berlin, Germany. 
Rützler K, Santavy D (1983). The black band disease of Atlantic coral reefs. PSZN I: Mar Ecol 4: 301-319.

Rützler K, Santavy D, Antonius A (1983). The black band disease of Atlantic coral reefs III: distribution, ecology, and development. PSZN I: Mar Ecol 4: 329-358.

Sato Y, Willis BL, Bourne DG (2009). Successional changes in bacterial communities during the development of black band disease on the reef coral, Montipora hispida. ISME J 1-12.

Sekar R, Mills DK, Remily ER, Voss JD, Richardson LL (2006). Microbial communities in the surface mucopolysaccharide layer and the black band microbial mat of black band diseased Siderastrea siderea. Appl Environ Microbiol 72: 5963-5973.

Sekar R, Kaczmarsky LT, Richardson LL (2008). Microbial community composition of black band disease on the coral host Siderastrea siderea from three regions of the wider Caribbean. Mar Ecol Prog Ser 362:85-98.

Sekar R, Kaczmarsky LT, Richardson LL (2009). Effect of freezing on PCR amplification of $16 \mathrm{~S}$ rRNA genes from microbes associated with black band disease of corals. Appl Environ Microbiol 75: 2581-2584.

Selig ER, Harvell CD, Bruno JF, Willis BL, Page CA, Casey KS, Sweatman H (2006). Analyzing the relationship between ocean temperature anomalies and coral disease outbreaks at broad spatial scales. p. 111-128. In JT Phinney (ed.) Coral reefs and climate change: science and management. AGU books, Washington, D.C.

Sokolow S (2009). Effects of a changing climate on the dynamics of coral infectious disease: a review of the evidence. Dis of Aquat Org 87: 5-18.

Spalding MD, Grenfell AM (1997). New estimates of global and regional coral reef areas. Coral Reefs 16(4): 225-230.

Squires DF (1965). Neoplasia in a coral? Science 148: 503-505.

Stanić D, Oehrle S, Gantar M, Richardson LL (2011). Microcystin production and ecological physiology of Caribbean black band cyanobacteria. Environ Microbio 13(4): 900-910. 
Sunagawa S, DeSantis TZ, Piceno YM, Brodie EL, DeSalvo MK, Voolstra CR, Weil E, Anderson GL, Medina M (2009). Bacterial diversity and whiteplague disease-associated community changes in the Caribbean coral Montastraea faveolata. ISME J 3: 512-521.

Sussman M, Bourne DG, Willis BL (2006). A single cyanobacterial ribotype is associated with both red and black bands on diseased corals from Palau. Dis Aquat Org 69:111-118.

Sutherland KP, Porter JW, Torres C (2004). Disease and immunity in Caribbean and Indo-Pacific zooxanthellate corals. Mar Ecol Prog Ser 266: 273-302.

Sutherland KP, Porter JW, Turner JW, Thomas BJ, Looney EE, Luna TP, Meyers MK, Futch JC, Lipp EK (2010). Human sewage identified as likely source of white pox disease of the threatened Caribbean elkhorn coral, Acropora palmata. Envir Microbio 12(5): 1122-1131.

Taylor DL (1983). The black band disease of Atlantic reef corals. II. Isolation, cultivation, and growth of Phormidium corallyticum. PSZNI: Mar Ecol 4: 320-328.

Viehman TS, Mills DK, Meichel GW, Richardson LL (2006). Culture and identification of Desulfovibrio spp. from black band disease of corals on reefs of the Florida Keys and Dominica. Dis Aquat Org 69:119-127.

Voss JD, Richardson LL (2006). Nutrient enrichment enhances black band disease progression in corals. Coral Reefs 25: 569-576.

Voss JD, Mills DK, Myers JL, Remily ER, Richardson LL (2007). Black band disease microbial community variation on corals in three regions of the wider Caribbean. Microb Ecol 54:730-739.

Weil E, Smith GW, Gil-Agudelo DL (2006). Status and progress in coral reef disease research. Dis of Aquat Org 69:33-40.

Wilkinson C (2008). Status of coral reefs of the world: 2008. Global Coral Reef Monitoring Network and Reef and Rainforest Research Centre, Townsville, Australia.

Williams EH, Bunkley-Williams L (1990). The world-wide coral reef bleaching cycle and other sources of coral mortality. Atoll Res Bull 335: 1-73.

Wolcott RD, Ehrlich GD (2008). Biofilms and chronic infections. JAMA 299(22): 2682-2684. 
CHAPTER II

A META-ANALYSIS OF 16S rRNA GENE CLONE LIBRARIES

FROM THE POLYMICROBIAL BLACK BAND DISEASE OF CORALS 


\begin{abstract}
Black band disease (BBD) is a polymicrobial disease affecting corals on reefs worldwide. Since 2002, researchers have constructed clone libraries from the BBD consortium using $16 \mathrm{~S}$ rRNA gene primers targeting a variety of phyla. In the present study, a meta-analysis was conducted of published libraries from 2002 through the present that contain bacterial sequence data associated with individual clones and BBD samples. The libraries analyzed were from 87 BBD samples, collected from 16 species of scleractinian corals in 10 different geographic locations, and included 327 unique operational taxonomic units (OTUs). One OTU (cyanobacterial) was present in 62 (71\%) samples, and three (one Cytophaga-Flavobacter-Bacteriodetes and two Alphaproteobacterial) were present in $11(13 \%)$ of the samples. The remaining 323 unique OTUs were present in $<10 \%$ of the samples. The Alphaproteobacteria was the most diversely represented group in the samples. Analysis of clone libraries using nonmetric multidimensional scaling indicated strong regional specificity of BBD microbial populations, but limited host coral specificity. The results of this analysis support the hypotheses that: (1) a specific cyanobacterium may be the primary pathogen of BBD; (2) additional functional groups, required for BBD pathobiology, are represented by variable opportunistic species; and (3) opportunistic BBD microorganisms are primarily derived from the environment.
\end{abstract}




\section{INTRODUCTION}

Coral disease is recognized as a significant contributor to the decline of coral cover worldwide (Dustan, 1999; Porter et al., 2001; Rosenberg \& Loya, 2004), particularly in the Caribbean where an estimated $80 \%$ of coral cover has been lost over the past three decades (Gardner et al., 2003). Together with this decline there has been an increase in the number, frequency, geographic distribution, and host range of coral diseases (Porter et al., 2001; Richardson \& Aronson, 2002; Weil, 2004; Harvell et al., 2005). Black band disease (BBD), one of the first coral diseases to be reported almost 40 years ago (Antonius, 1973), is a polymicrobial disease known to infect 64 scleractinian and six gorgonian coral species in the wider Caribbean and Indo-Pacific (Sutherland et al., 2004). It is considered one of the most important coral diseases world-wide because it generally affects massive reef-building corals and is often lethal. BBD is characterized by a dense, dark-colored band that separates apparently healthy tissue from freshly denuded skeleton. The band, which ranges from $1 \mathrm{~mm}$ to several $\mathrm{cm}$ in width and is up to $1 \mathrm{~mm}$ thick, migrates across apparently healthy tissue an average of $3 \mathrm{~mm} /$ day, and has the potential to kill an entire colony within months (Antonius, 1981a \& b; Rützler \& Santavy, 1983; Rützler et al., 1983).

Identification of the BBD primary pathogen (or pathogens) has been the subject of multiple microbiological and molecular investigations (Garrett \& Ducklow, 1975; Ducklow \& Mitchell, 1979; Rützler \& Santavy, 1983; Taylor, 1983; Cooney et al., 2002; Frias-Lopez et al., 2002, 2003, \& 2004; Barneah et 
al., 2007; Sekar et al., 2006, 2008, \& 2009; Sussman et al., 2006; Viehman et al., 2006; Myers et al., 2007; Arotsker et al., 2009; Sato et al., 2009), none of which have proven definitive. The disease is composed of a complex microbial mat, visually dominated by phycoerythrin-rich, gliding, filamentous cyanobacteria now known to include members of the genera Oscillatoria, Geitlerinema, Leptolyngbya (Cooney et al., 2002; Frias-Lopez et al., 2004; Myers et al., 2007) and a newly described genus, Roseofilum (Rasoulouniriana et al., 2009). Other dominant BBD microorganisms are sulfide-oxidizing bacteria purportedly belonging to the genus Beggiatoa (Garrett \& Ducklow, 1975; Mitchell \& Chet, 1975), sulfate-reducing bacteria that include several members of the Desulfovibrio genus (Garrett \& Ducklow, 1975; Viehman et al., 2006), and numerous heterotrophic bacteria (Cooney et al., 2002; Frias-Lopez, 2002, 2003; Sekar et al., 2006). Three BBD microorganisms, a cyanobacterium, Cytophaga sp., and the alphaproteobacterium Roseovarius crassostreae have been specifically targeted as potential primary pathogens (Rützler \& Santavy, 1983; Cooney et al., 2002; Frias-Lopez et al., 2004), however, Koch's postulates have not been fulfilled for any of them. Of these, Roseovarius crassostreae is a known pathogen and is the etiological agent of juvenile oyster disease (Boettcher et al., 2005). It has also been proposed that BBD is caused by a pathogenic consortium and that Koch's postulates therefore cannot be fulfilled for any primary pathogen (Richardson et al., 1997).

Several molecular studies have been conducted to characterize the BBD microbial community using cloning and sequencing and targeting a variety of 
phyla. These studies have for the most part utilized universal bacterial primers for the 16S rRNA gene (Cooney et al., 2002; Frias-Lopez et al., 2003; Sekar et al., 2006; Barneah et al., 2007; Arotsker et al., 2009; Sato et al., 2009). Other studies targeted specific phyla, for example using cyanobacterial specific $16 \mathrm{~S}$ rRNA gene primers (Frias-Lopez et al., 2002, 2004; Sussman et al., 2006; Myers et al., 2007; Sato et al., 2009). One study focused on the molecular identification of BBD sulfate-reducing bacteria (Viehman et al., 2006), and another focused on the genus Vibrio (Arotsker et al., 2009). In these studies the approach used was to first selectively culture and isolate bacteria of interest (sulfate-reducing bacteria and Vibrio $s p$.) and then clone and sequence the isolates using universal bacterial primers. Together, these studies have detected different cyanobacterial OTUs in BBD as well as sequences related to many other taxonomic groups, including Alphaproteobacteria, Betaproteobacteria, Gammaproteobacteria, and others.

When comparing the results of the different molecular studies of the BBD community it is evident that there is a great amount of variability in results from among and within research groups (Sekar et al., 2006). It is possible that all of the studies under-represent the true diversity of the BBD consortium, which could contribute at least partially to this variability. It is important to point out, however, that one study, based on microbial community profiling using lengthheterogeneity PCR (LH-PCR) and which implemented identical processing of samples, found considerable variability in the BBD community composition between geographic regions, between sites within a region, and between coral 
host species at the same sites (Voss et al., 2007), suggesting that the high degree of BBD microbial species variability includes geographic and host coral specificity. It is not known whether the basis of this variability is the result of a large number of opportunistic pathogens, or to multiple pathogens within a polymicrobial disease community. To assess this variability, a meta-analysis of

BBD clone libraries could yield important information concerning the composition of the BBD consortium. The objectives of the present analysis were to compare all BBD clone libraries published from 2002 through the present that were constructed using individual (i.e., not pooled) samples of BBD. Analysis consisted of sorting the sequence data based on phylum (or subdivision, depending on diversity), identification of OTUs present in single or multiple BBD samples, and assessment of regional and host coral species specificity of BBD microbial communities in individual samples using non-metric multidimensional scaling (NMDS).

\section{MATERIALS AND METHODS}

Clone libraries used in the meta-analysis

Sequence data (GenBank accession numbers) and percent similarity to the closest relative in GenBank for all published clone libraries constructed directly from individual BBD samples (Cooney et al., 2002; Frias-Lopez et al., 2002, 2003, and 2004; Sekar at al., 2006, 2008; Barneah et al. 2006; Myers et al., 2007; Arotsker et al. 2009, Sato et al., 2009), and from isolates from the BBD community that were cultured prior to molecular analysis (Sussman et al., 2006; 
Viehman et al., 2006; Meyers et al., 2007; Rasoulouniriana et al., 2009), were retrieved, totaling 10 papers published from 2002 to the present.

Clone libraries analyzed were constructed from a total of 87 BBD samples collected from 10 sites throughout the wider Caribbean and Indo-Pacific, representing 16 scleractinian host coral species. Sequences in the clone libraries ranged from 218 to 1546 base pairs per OTU. The data set analyzed is summarized in Table 1. Clones were considered to be the same OTU if they exhibited $97 \%$ or greater similarity following convention by conducting a BLASTN search in GenBank.

\section{Statistical analysis}

The NMDS plots were made comparing the similarity of OTUs within BBD samples between coral host species, and between collection sites to determine if any similarities were present. For these plots, clone libraries from host species/sites were chosen for inclusion only if there were at least three samples which were derived from a particular host species or sampling site. Bray-Curtis similarity matrices were constructed based on the OTUs present in each sample using a square-root transformation to provide more weight to the rare OTUs. From these matrices, non-metric multi-dimensional plots were constructed. Statistical analyses were conducted using Primer-E software (www.primere.com).

\section{RESULTS}

A total of 558 OTUs were generated from the 87 BBD samples. Of these, 327 were unique. For comparisons between BBD samples, OTUs were 
designated at the phylum or class level (depending on diversity within phyla). Sorting the OTUs into phylogenetic classes allowed for the determination of the OTUs that were commonly found in BBD, which were rarely found, and which taxonomic groups were most diversely represented.

\section{Diversity of OTUs}

The 327 bacterial OTUs present in the 87 BBD clone libraries sampled represented nine phyla and five subdivisions within the most diverse phylum (the Proteobacteria). One OTU (cyanobacterial) was present in $62(71 \%)$ of the 87 samples, and three OTUs (one CFB and two Alphaproteobacteria) were present in $11(13 \%)$ of the samples (Figure 1). The remaining 323 OTUs were present in only one to six (1-7\%) of the 87 samples, with four (two Alphaproteobacteria and two Deltaproteobacteria) found in six samples (7\%), six (five Alphaproteobacteria and one Deltaproteobacteria) present in five samples (6\%), 18 (various phyla) present in four samples (5\%), 15 (various phyla) found in three samples (4\%), and 39 (various phyla) found in two samples (2\%). There were 239 OTUs (various phyla) that were singletons (found in only one of the 87 samples; Figure 2).

The most common OTU (cyanobacterial) was present from nine of the ten sites, and 12 of the 16 coral host species sampled. However, only 79 of the 87 clone libraries constructed had the capability of detecting cyanobacterial sequences (even though the BBD community is visually dominated by cyanobacteria). Thus the presence of this sequence in 62 of 79 clone libraries equates to an adjusted presence in $78 \%$ of the samples. The taxonomic 
identification of this cyanobacterium will be discussed below. The second most abundant OTUs appeared in $11(13 \%)$ of the samples. These (three) OTUs were most closely homologous to a Cytophaga sp. and two Alphaproteobacteria (each 98\%) (Cooney et al. 2002).

The four OTUs present in the greatest number of BBD samples, summarized above, represent $0.9 \%$ of the 327 OTUs detected in the 87 BBD samples analyzed. Table 2 presents the identities of OTUs that were found in three or more of the samples, ranked with the most prevalent (cyanobacterium present in 62 samples) at the top, and those present in three samples at the bottom. Forty-eight of the 327 OTUs were present in three or more samples. These included members of the cyanobacteria, Alpha-, Delta-, and Gammaproteobacteria, the CFB, and the Firmicutes. Within these 48 there were only two cyanobacteria, a Geitlerinema sp. and Cyanobacterium PNG-50 (in addition to the cyanobacterium found in 62 samples), with each present in three of the 87 samples. Of the sulfur cycle bacteria (known to be important in BBD), there were three OTUs corresponding to sulfate reducing bacteria and one to a sulfide oxidizer. Nine OTUs corresponded to uncultured bacterial sequences, which included five sequences within the Firmicutes.

The phylogenetic association of OTUs that were found in more than one of the 87 BBD samples, grouped by taxonomic classification and depicted in terms of the number of BBD samples in which they were found, can be seen in Figure 1. The Alphaproteobacteria were the most diversely represented group as well 
as the dominant component in five of the seven sample size groupings, appearing in six of the seven groups (Figure 1).

The majority of OTUs identified ( $\mathrm{N}=239$, or $73 \%$ ) were present as singletons, appearing in only one of the $87 \mathrm{BBD}$ samples. Figure 2 shows the 239 singleton OTUs grouped by taxonomic classification, and demonstrates the relative diversity of the different taxonomic groups present in the BBD samples. From this figure it is clear that the Alphaproteobacteria are the most diversely represented, with 64 singleton OTUs, consistent with previous studies (Sekar et al., 2006). The second most diverse group was the Gammaproteobacteria, with 47 singleton OTUs. The Firmicutes, and the CFB groups were each represented by 20 OTUs, with the Deltaproteobacteria represented by 17 OTUs. The next most abundant group, which contained 15 OTUs, consisted of clones deposited as "unclassified bacteria" in GenBank. The cyanobacteria, although having the most prevalent OTU by far within the clone libraries, were not diversely represented, with only nine OTUs appearing as singletons (in addition to the three present in three or more samples).

Relative similarity of $B B D$ communities among samples

To assess similarities in the composition of BBD communities (clone libraries) among samples, NMDS plots were created comparing BBD communities and host coral species (Figure 3), and BBD communities and collection sites (Figure 4). Figure 3 shows a tight grouping of BBD communities associated with three colonies of the Australian coral Montipora hispida sampled at one site on the Great Barrier Reef. There were moderate groupings of BBD 
communities associated with two Caribbean host coral species, Diploria strigosa (30 colonies) and Siderastrea siderea (23 colonies), with both colonies sampled at multiple sites. Both of these groups had outliers. Montastraea cavernosa, $M$. annularis did not cluster together. The stress value for this plot was 0.05 , indicating that these results are significant (Kruskal, 1964).

Similarities of the BBD communities in terms of regional sites were apparent to a greater extent than host coral species (Figure 4). This was particularly true for BBD collected in Barbados, which formed a tight group. There were also distinct groupings for BBD communities from the Bahamas, and Pelorus Island sites. BBD communities from sites in the Florida Keys, Dominica, and New Britain were the most dissimilar, with samples from Curaçao and St. Croix moderately similar. The stress value was 0.01 for this plot, again indicating significance.

\section{DISCUSSION}

\section{Most common OTUs in BBD communities}

Results of the meta-analysis of clone libraries derived from 87 individual BBD samples clearly indicate the presence of a dominant OTU in BBD. This cyanobacterial OTU was first reported from BBD (accession no. AF473935) in 2002 (Cooney et al., 2002) as most closely related (92\% similarity) to Oscillatoria corallinae and deposited as "uncultured cyanobacterium" in GenBank. (Since that time there are $>100$ BBD cyanobacterial sequences that are $97 \%$ or higher in sequence similarity that have been similarly deposited as "uncultured" in GenBank.) The same sequence was detected multiple times in both black band 
and red band on reefs of Palau and deposited in GenBank as Oscillatoria sp. RMS1 (AY839639), Oscillatoria sp. RMS2 (AY839641) and Oscillatoria sp. BMS1 (AY839640) (Sussman et al., 2006). This sequence, obtained from BBD in the wider Caribbean, has also been referred to as BBD Oscillatoria (Myers et al., $2007,2009)$. Recently, a cyanobacterial strain with this sequence was isolated from BBD in the Red Sea and has been proposed in a non-systematic journal as a novel genus and species, Pseudoscillatoria coralii (Rasoulouniriana et al., 2009) and deposited in GenBank (FJ210722) under this name. None of these studies included rigorous phylogenetic or polyphasic taxonomic analysis, and we consider the phylogenetic placement (and name) of this cyanobacterium to be unresolved at present.

This cyanobacterial sequence appeared in $78 \%$ of the BBD samples that were capable of detecting cyanobacterial sequences. In addition to this, some clone libraries constructed may have been biased against the detection of cyanobacterial clones; see Sekar et al. (2009) for discussion of this issue. These results suggest that this cyanobacterium is an integral member of the BBD community on a global basis. Cultured isolates of this cyanobacterium have been shown, in laboratory investigations, to produce the cyanotoxin microcystin (Gantar et al., 2009) and to be resistant to sulfide (Myers and Richardson, 2009). Both of these properties are shared by other BBD cyanobacterial isolates, including members of the Geitlerinema and Leptolyngbya (Myers et al., 2007; Myers and Richardson, 2009; Gantar et al., 2009), and both properties are ecologically and etiologically significant. In terms of ecology, the BBD 
microenvironment is known to be sulfide rich (Carlton and Richardson, 1995), thus the ability to tolerate sulfide (normally toxic to cyanobacteria) would allow cyanobacteria to survive in the BBD mat. Additionally, it has been shown that sulfide is toxic to corals (Richardson et al., 1997). Production of microcystin by BBD cyanobacteria is also of etiological significance since it has been demonstrated that experimental exposure of healthy coral to purified microcystin results in coral tissue degradation that, when examined at the ultrastructural level, appears the same as coral tissue naturally affected by BBD (Richardson et al., 2009).

The second most abundant OTUs appeared in $11(13 \%)$ of the samples. There were three representatives in this category. One was most homologous to a Cytophaga sp. ( $97 \%$ sequence homology) from deep sea sediments, and the other two were most homologous to two Alphaproteobacteria associated with juvenile oyster disease (JOD). These were Rosevarius crassostreae, the JOD pathogen, and an unidentified Alphaproteobacterium. Representatives of these three bacteria have not been isolated into culture from BBD. Their role in BBD etiology is not known.

\section{The BBD microbial community}

The meta-analysis revealed the Alphaproteobacteria as the most diversely represented BBD group, with almost twice the number of singleton OTUs present compared to the second most diverse group, the Gammaproteobacteria. The Alphaproteobacteria is a diverse group of bacteria that include some of the most common bacteria in marine waters. Many Alphaproteobacteria are symbionts of 
marine plants and invertebrates (Shiba, 1991; Lafay et al., 1995; Ashen \& Goff, 1996; Barbieri et al., 1996; Burnett \& McKenzie, 1997). Within the clone libraries analyzed here three members of one order of Alphaproteobacteria, the Rhodobacteriales, were most prevalent. These (R. crassostreae, Roseobacter sp 8-1 and Roseobacter sp. DSS-8) were found in 13, 7, and $7 \%$ of the BBD samples respectively. Members of this order are metabolically highly flexible, and can grow as photoheterotrophs, facultative photoautotrophs, and chemotrophs. Some can grow as chemoorganotrophs with either strictly aerobic or facultatively anaerobic respiratory metabolism, as facultative fermenters, or as facultative methylotrophs (Garrity et al., 2005). The metabolic plasticity of the Alphaproteobacteria would be highly beneficial within the dynamic chemical microenvironment of the BBD mat.

Although the roles of individual Alphaproteobacteria in BBD are not known, their presence is consistent and diverse. The high number of singleton $\alpha$ proteobacteria OTUs suggests that this group contains a number of opportunistic bacteria that are able to thrive in the BBD mat environment. It was reported (and confirmed by phylogenetic analysis) that $5-18 \%$ of the Alphaproteobacteria detected in different BBD samples analyzed were associated with toxinproducing dinoflagellates (Sekar et al., 2006), suggesting that this group may be important in BBD pathobiology.

Additional phylogenetic groups detected as relatively prevalent in the BBD clone libraries (see Figures 1 and 2) included the Gammaproteobacteria, Deltaproteobacteria, the Firmicutes, and the CFB group. In terms of BBD 
etiology, only certain members of the Gammaproteobacteria (sulfide oxidizers and vibrios) and Deltaproteobacteria (sulfate reducers) are known, or implicated to be, important components of BBD. The sulfide oxidizers and sulfate reducers are known to be important due to their roles in the active BBD sulfuretum; in particular, the sulfate reducers are responsible for the toxic sulfide produced and accumulated in the band (Garrett \& Ducklow, 1975; Mitchell \& Chet, 1975; Richardson et al., 1997). Recently proteolytic activity of Vibrio sp. isolated from BBD in the Red Sea was demonstrated in the laboratory, and this group has been proposed to play an active role in the coral tissue lysis associated with BBD (Arotsker et al., 2009). The roles of members of the other dominant groups, as well as the lesser represented groups (see Figures 1 and 2), in BBD are not known. The potential role of each of these groups has been discussed at length in the papers from which clone libraries used in the meta-analysis were derived. BBD microbial communities, regional location, and coral host species

The results of the NMDS analysis strongly support previous reports that BBD communities are regionally specific (Frias-Lopez et al., 2003, 2004; Voss et al., 2007). Figure 4, which presents NMDS analysis of eight regions, shows very close similarities of BBD communities sampled in Barbados, New Britain, Pelorus Island, and the Bahamas. The communities from Curaçao and St. Croix were also clustered, although to a lesser extent. Two of the sites (Dominica and Florida Keys) did not show regional similarities on the basis of NMDS results.

When comparing BBD microbial communities in terms of host coral species (Figure 3), only two species (M. hispida, and $P$. lutea) exhibited highly 
similar BBD communities. Diploria strigosa, and to a lesser extent S. siderea, also were clustered although there were outliers for both. BBD communities associated with the remaining five coral host species were not similar. [It should be noted that in some cases (i.e. for $P$. lutea and $M$. cavernosa) symbols were located underneath other symbols, and cannot be discriminated in the figure.]

One question that has not been resolved is the source of bacteria in the complex BBD microbial community. It is likely that individual BBD microbial community members (species) originate from both the environment and the host coral. In support of the latter, some of the studies used in our analysis detected some OTUs common to both healthy coral and BBD samples (Frias-Lopez et al., 2002, 2004; Sekar et al., 2006). In one study, bacteria found at low abundance in healthy coral samples made up a significant fraction of the BBD consortium in infected corals (Frias-Lopez et al., 2004). On the other hand, Frias-Lopez et al. (2002) reported high numbers of sewage bacteria in BBD from colonies near sewage sources. While it has been demonstrated that bacterial populations associated with healthy corals are coral species specific (Rohwer et al., 2001, 2002; Ritchie and Smith, 2004), our results suggest that bacteria from the environment are more important in determining BBD community composition. For example, in Figure 3, the only tightly clustered BBD community analyzed based on hosts coral species was from BBD on the host $M$. hispida. These three samples were obtained from the same reef site. In terms of environment, the most tightly clustered BBD communities were sampled in Barbados, the Bahamas, and the Pelorus Islands. Of these, three different coral species were 
sampled from Barbados ( $M$. annularis, C. natans, and $D$. strigosa). The other two sites are not definitive, since only one species was sampled from the Bahamas and Pelorus Island (S. siderea and M. hispida respectively).

Comparison of the 87 clone libraries derived from individual BBD samples provided insight not possible within individual studies. In particular, NMDS results suggest that greater specificity is present with respect to region than to host coral species. These results support the hypothesis that most of the BBD bacteria are opportunistic, such that they are recruited from the local environment. For example, two OTUs, each present in $7 \%$ of the clone libraries, belong to the genus Roseobacter. These bacteria are known to comprise more than $20 \%$ of the coastal marine bacterioplankton community (Buchan et al., 2005). Similarly, the sequence related to Cytophaga sp. which comprised $13 \%$ of the BBD clones libraries is a part of the normal flora of marine sediments (Cooney et al., 2002). This interpretation does not negate the likelihood that individual members of the extremely diverse BBD community are recruited from the host coral. It is well known that both coccoid and filamentous cyanobacteria make up a significant component of both the epilithic and endolithic microbial community of corals (Hutchings, 1986; Peyrot-Clausade et al., 1995; Pari et al., 1998; Vogel et al., 2000; Rohwer et al., 2001; Lesser et al., 2007), and sequences corresponding to the most common BBD cyanobacterium were found to be abundant in samples from healthy corals on reefs of Curaçao (Klaus et al., 2007).

The analysis presented here aids in the understanding of the composition of one of the most important coral diseases. It supports previous proposals that 
specific species of pathogenic cyanobacteria may be primary BBD pathogens (Rützler \& Santavy, 1983; Voss et al., 2007), which may create an environment that is conducive for the growth of the microbial community that constitutes the BBD consortium. Our results also support the proposal that this coral disease may contain numerous opportunistic microorganisms (Lesser et al., 2007) that are primarily derived from the reef environment, and to a lesser extent the coral host.

\section{ACKNOWLEDGMENTS}

This is contribution number 190 from the Tropical Biology Program at Florida International University, previously published in the journal FEMS Microbiology Ecology. 


\section{REFERENCES}

1. Antonius A (1973). New observations on coral destruction in reefs. 10th Meet Assoc IsI Mar Lab Carib 10:3.

2. Antonius A (1981). The 'band' diseases in coral reefs. Proc 4th Int Coral Reef Symp 2:7-14.

3. Antonius A (1981). Coral reef pathology: a review. Proc 4th Int Coral Reef Symp 2:3-6.

4. Arotsker L, Siboni N, Ben-Dov E, Kramasky-Winter E, Loya Y, Kushmaro A (2009). Vibrio sp. as a potentially important member of the black band disease consortium in Favia sp. corals. FEMS Microbio Eco 70:3 515524.

5. Ashen JB, Goff LJ (1996). Molecular identification of a bacterium associated with gall formation in the marine red alga Prionitis lanceolata. $\mathrm{J}$ of Phyco 32:286-297.

6. Barbieri E, Gulledge J, Moser DP, Chien CC (1996). New evidence for bacterial diversity in the accessory cnidamental gland of the squid Loligo pealei. Biol Bull 191:316-317.

7. Barneah O, Ben-Dov E, Kramarsky-Winter E, Kushmaro A (2007). Characterization of black band disease in Red Sea stony corals. Environ Microbiol 9:1995-2006.

8. Boettcher KJ, Geaghan KK, Maloy AP, Barber BJ (2005). Roseovarius crassostreae sp. nov., a member of the Roseobacter clade and the apparent cause of juvenile oyster disease (JOD) in cultured Eastern oysters. Int J Syst Evol Microbiol 55:1531-1537.

9. Buchan A, Gonzalez JM, Moran MA (2005). Overview of the marine Roseobacter lineage. Appl Envir Microbio 71:5665-5677.

10. Burnett WJ, McKenzie JD (1997). Subcuticular bacteria from the brittle star Ophiactis balli represent a new lineage of extracellular marine symbionts in the a subdivision of the class Proteobacteria. Appl Environ Microbiol 63:1721-1724.

11. Carlton RG, Richardson LL (1995). Oxygen and sulfide dynamics in a horizontally migrating cyanobacterial mat: black band disease of corals. FEMS Microbiol Ecol 18:155-162. 
12. Cooney RP, Pantos O, Le Tissier MDA, Barer MR, O'Donnell AG, Bythell JC (2002). Characterization of the bacterial consortium associated with black band disease in coral using molecular microbiological techniques. Environ Microbiol 4:401-413.

13. Ducklow HW, Mitchell R (1979). Observations on naturally and artificially diseased tropical corals: A scanning electron microscope study. Microb Ecol 5:215-223.

14. Dustan $P$ (1999). Coral reefs under stress: sources of mortality in the Florida Keys. Nat Resour Forum 23:147-155.

15. Frias-Lopez JA, Zerkle L, Bonheyo GT, Fouke BW (2002). Partitioning of bacterial communities between seawater and healthy, black band diseased, and dead coral surfaces. Appl Environ Microbiol 68:2214-2228.

16. Frias-Lopez JA, Bonheyo GT, Jin QS, Fouke BW (2003). Cyanobacteria associated with coral black band disease in Caribbean and Indo-Pacific reefs. Appl Environ Microbiol 69:2409-2413.

17. Frias-Lopez JA, Klaus JS, Bonheyo GT, Fouke BW (2004). Bacterial community associated with black band disease in corals. Appl Environ Microbiol 70:5955-5962.

18. Gantar M, Sekar R, Richardson LL (2009). Toxicity of culturable cyanobacteria associated with black band disease of corals. Microb Ecol 58:856-864.

19. Gardner TA, Cote IM, Gill JA, Grant A, Watkinson AG (2003). Long-term region-wide declines in Caribbean corals. Science 301:958-960.

20. Garrett P and Ducklow H (1975). Coral disease in Bermuda. Nature 253:349-350.

21. Garrity GM, Bell JA, Lilburn T (2005). Class I Alphaproteobacteria. Berg Man Syst Det Bac 2. Springer. Verlag. pp. 161-229.

22. Harvell CD, Kim K, Burkholder JM, et al. (1999). Emerging marine diseases - climate links and anthropogenic factors. Science 285:15051510.

23. Hutchings PA (1986). Biological descruction of coral reefs: a review. Coral Reefs 4:239-252. 
24. Klaus JS, Frias-Lopez JA, Bonheyo GT, Heikoop JM, Fouke BW (2007). Bacterial communities inhabiting the healthy tissues of two Caribbean reef corals: interspecific and spatial variation. Coral Reefs 24:129-137.

25. Kruskal JB (1964). Multidimensional scaling by optimizing goodness of fit to a nonmetric hypothesis. Phsychometrika 29:1-27.

26. Lafay B, Ruimy R, Rausch de Traubenberg C, Breitmayer V, Gauthier MJ, Christen R (1995). Roseobacter algicola, a new marine bacterium isolated from the phycosphere of the toxin-producing dinoflagellate Prorocentrum lima. Int J Syst Bacteriol 45:290-296.

27. Lesser MJ, Bythell JC, Gates R, Johnstone R, Hoegh-Guldberg O (2007). Are infectious diseases really killing corals? Alternative interpretations of experimental and ecological data. J Exp Mar Bio Eco 346:36-44.

28. Mitchell R, Chet I (1975). Bacterial attack of corals in polluted seawater. Microb Ecol 2:227-233.

29. Myers JL, Sekar R, Richardson LL (2007). Molecular detection and ecological significance of the cyanobacteria Geitlerinema and Leptolyngbya in black band disease of corals. Appl Environ Microbiol 73:5173-5182.

30. Myers JL, Richardson LL (2009). Adaptation of cyanobacteria to the sulfide-rich microenvironment of black band disease of coral. FEMS Microbiol Ecol 67:242-251.

31. Pari N, Peyrot-Clausade M, Le Campion-Alsumard T, Hutchings $P$, Chazottes V, Golubic S, Le Campion J, Fontaine MF (1998). Bioerosion of experimental substrates on high islands and on atoll lagoons after two years of exposure. Mar Ecol Prog Ser 166:119-130.

32. Peyrot-Clausade M, Le Campion-Alsumard T, Harmelin-Vivien M, Romano JC, Chazottes V, Pari N, Le Campion J (1995). La bioérosion dans le cycle des carbonates: essais de quantification des processus en Polynésie francaise. Bull Soc Géol France 166:85-94.

33. Porter J, Dustan P, Jaap W, Patterson K, Kosmynin W, Meier O, Patterson M, Parsons M (2001). Patterns of spread of coral disease in the Florida Keys. Hydrobiologia 460:1-24. 
34. Rasoulouniriana D, Siboni N, Ben-Dov E, Kramarsky-Winter E, Loya Y, Kushmaro A (2009). Pseudoscillatoria coralii gen. nov., sp. nov., a cyanobacterium associated with coral black band disease. Dis of Aquat Org 87: 91-96.

35. Richardson LL, Kuta KG, Schnell S, Carlton RG (1997). Ecology of the black band disease microbial consortium. Proc 8th Int Coral Reef Symp 1:597-600.

36. Richardson LL, Aronson RB (2002). Infectious diseases of reef corals. Proc 9th Int Coral Reef Symp 2:1225-1230.

37. Richardson LL, Miller AW, Broderick E, Kaczmarsky L, Gantar M, Stanić D, Sekar R (2009). Sulfide, microcystin, and the etiology of black band disease. Dis of Aquat Organ 87:79-90.

38. Ritchie KB, GW Smith (2004). Microbial communities of coral surface mucopolysaccharide layers. p. 259-264. In E. Rosenberg and Y. Loya (ed.), Coral health and disease. Springer, Berlin.

39. Rohwer F, Breitbart M, Jara J, Azam F, Knowlton N (2001). Diversity of bacteria associated with the Caribbean coral Montastraea franksi. Coral Reefs 20:85-91.

40. Rohwer F, Segritan V, Azam F, Knowlton N (2002). Diversity and distribution of coral-associated bacteria. Mar Ecol Prog Ser 243:1-10.

41. Rosenberg E, Loya Y (2004). Coral Health and Disease. Springer, Berlin.

42. Rützler K, Santavy D (1983). The black band disease of Atlantic reef corals. I. Description of the cyanophyte pathogen. PSZNI: Mar Ecol 4:301319.

43. Rützler K, Santavy D, Antonius A (1983). The black band disease of Atlantic reef corals. III. Distribution, ecology and development. PSZNI: Mar Ecol 4:329-358.

44. Sato Y, Willis BL, Bourne DG (2009). Successional changes in bacterial communities during the development of black band disease on the reef coral, Montipora hispida. ISME J 1-12.

45. Sekar R, Mills DK, Remily ER, Voss JD, Richardson LL (2006). Microbial communities in the surface mucopolysaccharide layer and the black band microbial mat of black band diseased Siderastrea siderea. Appl Environ Microbiol 72:5963-5973. 
46. Sekar R, Kaczmarsky LT, Richardson LL (2008). Microbial community composition of black band disease on the coral host Siderastrea siderea from three regions of the wider Caribbean. Mar Ecol Prog Ser 362:85-98.

47. Sekar R, Kaczmarsky LT, Richardson LL (2009). Effect of freezing on PCR amplification of $16 \mathrm{~S}$ rRNA genes from microbes associated with black band disease of corals. Appl Environ Microbiol 75:2581-2584.

48. Shiba T (1991). Roseobacter litoralis and Roseobacter denitrificans, aerobic pink-pigmented bacteria which contain bacteriochlorophyll a. Syst Appl Microbiol 14:140-145.

49. Sussman M, Bourne DG, Willis BL (2006). A single cyanobacterial ribotype is associated with both red and black bands on diseased corals from Palau. Dis Aquat Org 69:111-118.

50. Sutherland KP, Porter JW, Torres C (2004). Disease and immunity in Caribbean and Indo-Pacific zooxanthellate corals. Mar Ecol Prog Ser 266:273-302.

51. Taylor DL (1983). The black band disease of Atlantic reef corals. II. Isolation, cultivation, and growth of Phormidium corallyticum. PSZNI: Mar Ecol 4:320-328.

52. Viehman TS, Mills DK, Meichel GW, Richardson LL (2006). Culture and identification of Desulfovibrio spp. from black band disease of corals on reefs of the Florida Keys and Dominica. Dis Aquat Org 69:119-127.

53. Vogel K, Gektidis M, Golubic S, Kiene WE, Radtke G (2000). Experimental studies on microbial bioerosion at Lee Stocking Island, Bahamas, and One Tree Island, Great Barrier Reef, Australia: implications for paleoecological reconstructions. Lethaia: Int J Palaeon Stratigraph 33:190-204.

54. Voss JD, Mills DK, Myers JL, Remily ER, Richardson LL (2007). Black band disease microbial community variation on corals in three regions of the wider Caribbean. Microb Ecol 54:730-739.

55. Weil E (2004). Coral reef diseases in the Wider Caribbean, p. 35-68. In E. Rosenberg and Y. Loya (ed.) Coral health and disease. Springer, Berlin. 
Table 1. Data set used in the meta-analysis.

\begin{tabular}{|c|c|c|c|c|c|}
\hline Reference & Host coral species & $\begin{array}{l}\text { \# of BBD } \\
\text { samples* }\end{array}$ & $\begin{array}{l}\text { Total \# of } \\
\text { OTUs }\end{array}$ & $\begin{array}{l}\text { Number of base } \\
\text { pairs sequenced }\end{array}$ & Site \\
\hline Cooney et al. (2002) & $\begin{array}{l}\text { Diploria strigosa, Montastraea annularis, } \\
\text { Colpophylia natans }\end{array}$ & 11 & 83 & $\sim 500$ & St. Croix, USVl; Barbados \\
\hline $\begin{array}{l}\text { Frias-Lopez et al. } \\
(2002)\end{array}$ & M. annularis, $M$. cavernosa, D. strigosa & 3 & 63 & $218-698$ & Curaçao, the Netherlands Antilles \\
\hline $\begin{array}{l}\text { Frias-Lopez et al. } \\
(2003)\end{array}$ & $\begin{array}{l}\text { M. annularis, M. cavernosa, D. strigosa, } \\
\text { Porites lutea }\end{array}$ & 11 & 11 & $300-600$ & Curaçao, the Netherlands Antilles \\
\hline $\begin{array}{l}\text { Frias-Lopez et al. } \\
\text { (2004) }\end{array}$ & M. annularis, D. strigosa, P. lutea & 12 & 43 & $245-607$ & $\begin{array}{l}\text { Curaçao, the Netherlands Antilles; } \\
\text { New Britain, Papua New Guinea }\end{array}$ \\
\hline Sekar etal. (2006) & Siderastrea siderea & 2 & 77 & $431-1546$ & Lee Stocking Island, Bahamas \\
\hline Sussman etal. (2006) & $\begin{array}{l}\text { Porites sp., Pachyseris speciosa, } \\
\text { Montipora sp. }\end{array}$ & 3 & 3 & 582 & Palau; Hawaii \\
\hline Viehman et al. (2006) & $\begin{array}{l}\text { D. strigosa, S. siderea, D. divosa, D. } \\
\text { labyrinthiformis }\end{array}$ & 6 & 10 & $241-1536$ & Florida Keys; Dominica \\
\hline Myers et al. (2007) & $\begin{array}{l}\text { M. cavernosa, S. siderea, Meandrina } \\
\text { meandrites, Solenastrea sp., Dichocoenia } \\
\text { stokesi, Dendrogyra cylindrus }\end{array}$ & 29 & 31 & $1396-1461$ & $\begin{array}{l}\text { Florida Keys; Lee Stocking Island, } \\
\text { Bahamas; St. Croix, USVI; Negros } \\
\text { Island, Philippines }\end{array}$ \\
\hline Sekar et al. (2008) & S. siderea & 7 & 160 & $431-1546$ & $\begin{array}{l}\text { Lee Stocking Island, Bahamas; } \\
\text { Florida Keys; St. Croix, USVI }\end{array}$ \\
\hline Sato et al. (2009) & M. hispida & 3 & 76 & $\mathrm{NP}^{\dagger}$ & Pelorus Island, Australia \\
\hline Total & 16 species & 87 & 558 & & 10 sites \\
\hline
\end{tabular}

${ }^{a}$ Each sample produced one clone library.

bSequence lengths were not provided in this study. 
Table 2. OTUs present in three or more of the 87 BBD clone libraries analyzed.

Percent similarity is the relatedness of OTUs between studies.

\begin{tabular}{|c|c|c|c|c|c|}
\hline $\begin{array}{l}\text { I of BBD } \\
\text { Samples } \\
\text { Containing this } \\
\text { OTU }\end{array}$ & $\begin{array}{l}\text { OTU Identifled In } \\
\text { GenBank }\end{array}$ & $\begin{array}{l}\text { Phylogenetic } \\
\text { Aftilation }\end{array}$ & $\begin{array}{l}\text { Accession } \\
\text { Number }\end{array}$ & $\begin{array}{l}\text { Percent Simliarity Between } \\
\text { Librarles" }\end{array}$ & $\begin{array}{l}\text { Clone Library in which } \\
\text { sequence was } \\
\text { Detected" }\end{array}$ \\
\hline 62 & $\begin{array}{l}\text { Uncultured } \\
\text { cyanobacterium, } \\
\text { Osciloborta, } \\
\text { Pesudoscilionla coravf }\end{array}$ & Cyanobocteris & $\begin{array}{l}\text { AF473935 } \\
\text { AY038527 } \\
\text { AY839639-41 }\end{array}$ & $98-99$ & 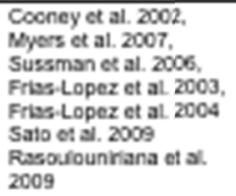 \\
\hline 11 & Cytaphogesp. & $\mathrm{CFB}$ & $\begin{array}{l}\text { EF } 123557 \\
\text { ABO15260 }\end{array}$ & 97 & $\begin{array}{l}\text { Cocney et al. } 2002 \text {, } \\
\text { Friss Lopez et at. } 2002 \text {, } \\
\text { Sekar or al. } 2008\end{array}$ \\
\hline 11 & $\begin{array}{l}\text { Roseovanis crassostrove } \\
\text { CV919-312 }\end{array}$ & aprotocbocteris & $\begin{array}{l}\text { Do445100-106 } \\
\text { Do445154-156 } \\
\text { EF123390-95 } \\
\text { AF1144!4 }\end{array}$ & 94.97 & $\begin{array}{l}\text { Cocney et al. } 2002 \text {, } \\
\text { Sekar of al. } 2008\end{array}$ \\
\hline 11 & $\begin{array}{l}\text { Alpho procheceacteritum in } \\
\text { JOD }\end{array}$ & a. problocbscteris & AF1144:5 & Ss & Cocney et al. 2002 \\
\hline 6 & $\begin{array}{l}\text { Rosoobucter sp 8-1 } \\
\text { (AJ536570), Roseabseter } \\
\text { sp DSS-8 (AFose493) }\end{array}$ & aprovocbscteris & $\begin{array}{l}\text { DO446094-101 } \\
\text { DO445145-61 } \\
\text { EF123385-89 }\end{array}$ & Ss & Sekar of al. 2000 \\
\hline 6 & $\begin{array}{l}\text { SWabacter } \\
\text { tacuscaenitensis (UT7644) }\end{array}$ & a. provocbscteris & AF 473934 & Ss & Cooney et al. 2002 \\
\hline 6 & $\begin{array}{l}\text { Dosultoulbrib sp. } \\
\text { (AF228128) }\end{array}$ & 8.Probecobacteria & AF473924 & So & Cocney et al. 2002 \\
\hline 6 & $\begin{array}{l}\text { Uncultured deta } \\
\text { procecbacterium dione } \\
\text { Co13810 }\end{array}$ & o. Probecobacterla & $\begin{array}{l}\text { Ar907525 } \\
\text { AF090830 }\end{array}$ & 97 & $\begin{array}{l}\text { Friss-Lopez et al. } 2002 \text {, } \\
\text { Vetman et al. } 2005\end{array}$ \\
\hline 5 & $\begin{array}{l}\text { Alpha protecbacterlum } \\
\text { (AJ533975). Alphs } \\
\text { probecbacterium } \\
\text { MBIC1876 (AB 026194) }\end{array}$ & aproteobocteria & EF12329 & Ss & Sekar of al. 2008 \\
\hline 5 & $\begin{array}{l}\text { Alphaprotecbacterium } \\
\text { C116-18 (AJ224357) }\end{array}$ & aproteobocteris & $\begin{array}{l}\text { Dos4400e-15 } \\
\text { EF123307-10 }\end{array}$ & Ss & Sekar os al. 2008 \\
\hline 5 & $\begin{array}{l}\text { Thavassobivs } \\
\text { medtevraneus (Aus78a74) }\end{array}$ & a-provocbscteris & $\begin{array}{l}\text { Do446171.172 } \\
\text { EF123417.33 }\end{array}$ & So & Sekar of al. 2000 \\
\hline 5 & $\begin{array}{l}\text { Ochrobsctim sp. TD } \\
\text { (AY623625) }\end{array}$ & appolectbocteris & $\begin{array}{l}\text { Do446092.93 } \\
\text { DO446142-143 } \\
\text { EF123437.41 }\end{array}$ & Ss & Sekar of al. 2008 \\
\hline 5 & $\begin{array}{l}\text { Sunde oxidzing bacteria } \\
\text { (U46518) }\end{array}$ & Esprotocbacteris & AF473944 & Ss & Cooney et al. 2002 \\
\hline 5 & $\begin{array}{l}\text { Suttrobacter sp. ARCTC. } \\
\text { P49 (AY573043) }\end{array}$ & apposecbocteris & $\begin{array}{l}\text { Do446110, } \\
\text { D0446166-167 }\end{array}$ & $98 \cdot 99$ & $\begin{array}{l}\text { Sekar of al. } 2000, \text { Sato } \\
\text { et al. } 2009\end{array}$ \\
\hline 4 & $\begin{array}{l}\text { Fhodobactersceso } \\
\text { bacterium (AF5 13932,34, } \\
36\end{array}$ & apeotocbosteris & EF123339.52 & Ss & Sekar of al. 2008 \\
\hline 4 & $\begin{array}{l}\text { Ruegenia sp. AS-36 } \\
\text { (AJ391197) }\end{array}$ & appolocbscteris & $\begin{array}{l}\text { DO446157-160 } \\
\text { EF123405-07 }\end{array}$ & Sa & Sekar of al. 2008 \\
\hline 4 & $\begin{array}{l}\text { Swabacter sp. E923 } \\
\text { (AY369990) }\end{array}$ & aprovectoscteris & $\begin{array}{l}\text { Do446161-162 } \\
\text { EF123408-11 }\end{array}$ & Ss & Sekar \& al. 2008 \\
\hline 4 & $\begin{array}{l}\text { Sinorhizabitm sp. } \\
\text { (A.012211) (AN12210) }\end{array}$ & appotocbocteris & $\begin{array}{l}\text { EF123453-58 } \\
\text { DO445163-165 }\end{array}$ & Ss & Sekar of al. 2008 \\
\hline 4 & $\begin{array}{l}\text { Garma protecbacterium } \\
\text { KTC1119 (AF235120) }\end{array}$ & r.proteobacteria & $\begin{array}{l}\text { Do446111 } \\
\text { EF123461-64 }\end{array}$ & Ss & Sekar os al. 2008 \\
\hline 4 & $\begin{array}{l}\text { Desulovibrio pronindes } \\
\text { (AF418172) }\end{array}$ & A-protocbacteris & EF123503-514 & Ss & Sekar of al. 2008 \\
\hline
\end{tabular}




\begin{tabular}{|c|c|c|c|c|c|}
\hline 4 & $\begin{array}{l}\text { Uncutured CFB group } \\
\text { bacterium }\end{array}$ & CFB & AY497293 & Ss & Friss-Lopez et at. 2004 \\
\hline 4 & $\begin{array}{l}\text { Uncutured Fimicutes } \\
\text { clone CD4B11 }\end{array}$ & Fimicutes & AY497294 & Ss & Friss-Lopez et at. 2004 \\
\hline 4 & $\begin{array}{l}\text { Uncutured Firmicutes } \\
\text { clone CD5D10 }\end{array}$ & Fimicutes & AY497296 & Ss & Friss Lopez et al. 2004 \\
\hline 4 & Cytophogu fermentans & CFB & AY497296 & $\mathrm{Sa}$ & Friss-Lopez et at. 2004 \\
\hline 4 & $\begin{array}{l}\text { Uncutured Firmicutes 128- } \\
3.5\end{array}$ & Fimicutes & AY497297 & Sa & Friss-Lopez et al. 2004 \\
\hline 4 & $\begin{array}{l}\text { Uncutured Firmicutes } \\
\text { clone CDSC11 }\end{array}$ & Fimicutes & AY497298 & $\mathrm{Sa}$ & Friss Lopez et at. 2004 \\
\hline 4 & $\begin{array}{l}\text { Uncutured bacterium p- } \\
1921.5952 .3\end{array}$ & & AY497299 & Sa & Friss-Lopez et al. 2004 \\
\hline 4 & $\begin{array}{l}\text { Uncuftured 8- } \\
\text { probecbacterium 125.9-6 }\end{array}$ & E-protocbactorls & AY497300 & Ss & Friss-Lopez et at. 2004 \\
\hline 4 & cubacterium (AF159655) & a. peolocbacteris & AF473916 & $\mathrm{Ss}$ & Cooney et al. 2002 \\
\hline 4 & $\begin{array}{l}\text { Bdelbubno sp. } \\
\text { (AFos4850) }\end{array}$ & E-protocbacterla & AF473947 & Ss & Cooney et at. 2002 \\
\hline 4 & $\begin{array}{l}\text { Desulkovibrio sp. strain } \\
\text { TeP.1 }\end{array}$ & E-grotoobactoris & AY750147 & Ss & Vehman ef a. 2005 \\
\hline 4 & $\begin{array}{l}\text { Fonodobacteracese } \\
\text { bacterhm CL-TAD3 } \\
\text { (AY962292) }\end{array}$ & a. peolocbasteris & EF123333-38 & 98 & $\begin{array}{l}\text { Sekar ox al. 2008, Saso } \\
\text { et al. } 2006\end{array}$ \\
\hline 3 & $\begin{array}{l}\text { Ajpha protecbacterim } \\
\text { PTB1 (AF260725) }\end{array}$ & aproteobocteris & $\begin{array}{l}\text { D0446037-88 } \\
\text { DO544006-07 }\end{array}$ & $\mathrm{Sa}$ & Sekar of al. 2000 \\
\hline 3 & $\begin{array}{l}\text { Fhodobacterscese } \\
\text { bacterimm (A.1810644, 37) }\end{array}$ & apeotocbscteris & EF123329-32 & So & Sekar of al. 2008 \\
\hline 3 & $\begin{array}{l}\text { Fododobacteracese } \\
\text { bacterim CL-TAD3 } \\
\text { (AY962292) }\end{array}$ & aprolecbscieria & EF123333-38 & Ss & Sekar of al. 2008 \\
\hline 3 & $\begin{array}{l}\text { Roseabscter } 29.667 .19 \\
\text { (A.J294366) }\end{array}$ & apeotecbscteris & $\begin{array}{l}\text { DO446162 } \\
\text { DO544017.18 }\end{array}$ & $\mathrm{Sa}$ & Sekar of al. 2008 \\
\hline 3 & Uncultured firmicule & Fimicutes & $\begin{array}{l}\text { EF123527-28 } \\
\text { AF } 473930\end{array}$ & $97 \cdot 98$ & $\begin{array}{l}\text { Cocney et al. } 2002 \text {, } \\
\text { Sekar of al. } 2008\end{array}$ \\
\hline 3 & $\begin{array}{l}\text { Clostrictum subatanticum } \\
\text { (AF458779) }\end{array}$ & Fimicutes & $\begin{array}{l}\text { DO446118 } \\
\text { EF123532-33 }\end{array}$ & Ss & Sekar of al. 2008 \\
\hline 3 & $\begin{array}{l}\text { Flexbacter sagrogans } \\
\text { (ABOT1003s) }\end{array}$ & CFB & $\begin{array}{l}\text { DO446174 } \\
\text { EF123560-61 }\end{array}$ & Ss & Sekar of al. 2008 \\
\hline 3 & Cyanobsctertum PNG-50 & Cyanobocteris & AY 123040 & 97 & $\begin{array}{l}\text { Frios-Lopez et at. } 2003 \text {. } \\
2004\end{array}$ \\
\hline 3 & $\begin{array}{l}\text { Gatharnems } 29 . \text { BBD } \\
\text { (D0151461) }\end{array}$ & Cyanobocteris & EF110974 & Ss & Meyers et al. 2007 \\
\hline 3 & $\begin{array}{l}\text { Fusibacter sp. } \\
\text { (AB189368) }\end{array}$ & Fimicutes & $\begin{array}{l}\text { DO446120, } \\
\text { EF123534 }\end{array}$ & 98.99 & $\begin{array}{l}\text { Sekar or al. 2008, Sato } \\
\text { et al. } 2009\end{array}$ \\
\hline 3 & $\begin{array}{l}\text { Denitronibvio } \\
\text { acetiphilus (AF146526) }\end{array}$ & Deferrbacieres & EF123565-67 & 98 & $\begin{array}{l}\text { Sekar } \propto \text { al. } 2000, \text { Sa10 } \\
\text { et al. } 2009\end{array}$ \\
\hline 3 & $\begin{array}{l}\text { Ocesnospirillum sp. } \\
\text { MED92 (AY136116) }\end{array}$ & Vproteobacteria & EF123481 & 96.98 & $\begin{array}{l}\text { Sekar of al. } 2000 \text {, Sato } \\
\text { et al. } 2009\end{array}$ \\
\hline 3 & $\begin{array}{l}\text { Uncultured } \\
\text { alphsprosscbacierium } \\
\text { EF3905[EF 657852] }\end{array}$ & aprolocbacteria & GQ204841 & Ss & Sato of al. 2009 \\
\hline 3 & $\begin{array}{l}\text { Uncutured } \\
\text { Pyoudoadovomonas sp. } \\
\text { M26-004[AMS41176] }\end{array}$ & Y.proteobacteria & GC204891 & Sa & Sato of al. 2009 \\
\hline 3 & $\begin{array}{l}\text { Adovamonas sp. AS } \\
\text { 31[A.J91192] }\end{array}$ & Y-proteobacteria & GO204895 & Sa & Sato of al. 2009 \\
\hline 3 & $\begin{array}{l}\text { Aganinorans abus } \\
\text { MKTB6[AB 076558] }\end{array}$ & Y.proteobacteria & GQ204899 & Ss & Sato et al. 2009 \\
\hline
\end{tabular}

aTUs present in multiple samples from the same study are assumed to be the same OTU (greater than $97 \%$ homology) and are designated as ss.

${ }^{\mathrm{b}}$ OTUs presented in Sekar et al. 2006 were also presented in Sekar et al. 2008, and therefore are treated as a single study.

${ }^{c}$ Accession numbers were not provided for these OTUs 


\section{FIGURE LEGENDS}

Figure 1. Number of OTUs appearing in multiple samples (more than one clone library) of BBD presented by phylogenetic association and appearance in individual samples within the total data set (87 samples).

Figure 2. Phylogenetic associations of the 239 singleton OTUs present in the clone libraries generated from 87 individual BBD samples.

Figure 3. NMDS plot depicting similarities between BBD microbial communities and the host coral species from which they were collected. Coral host species were included in this analysis only if at least three BBD samples were collected from the species $(N=75)$. Some symbols are not visible because they were plotted directly on top of the same symbol (Porites lutea, Diploria strigosa, Siderastrea siderea) or are underneath other symbols (Montastraea cavernosa).

Figure 4. NMDS plot depicting similarities microbial communities and the regional sample site from which they were collected. Sites were included in this analysis only if at least three BBD samples were collected from the site $(\mathrm{N}=85)$. Some symbols are not visible because they were plotted directly on top of the same symbol (New Britain, Curaçao, Dominica) or are underneath other symbols (St. Croix, Florida Keys). 
Figure 1.

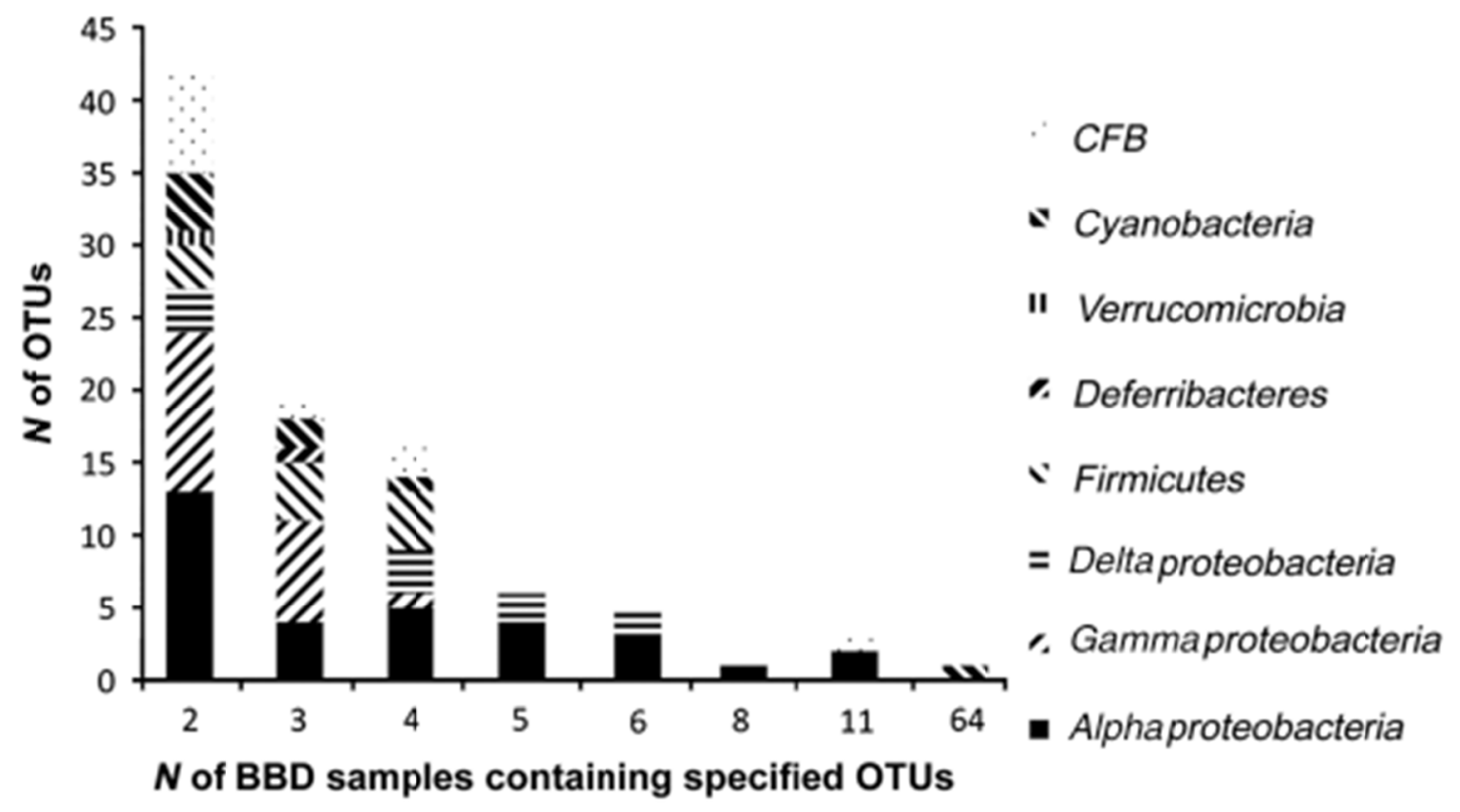


Figure 2.

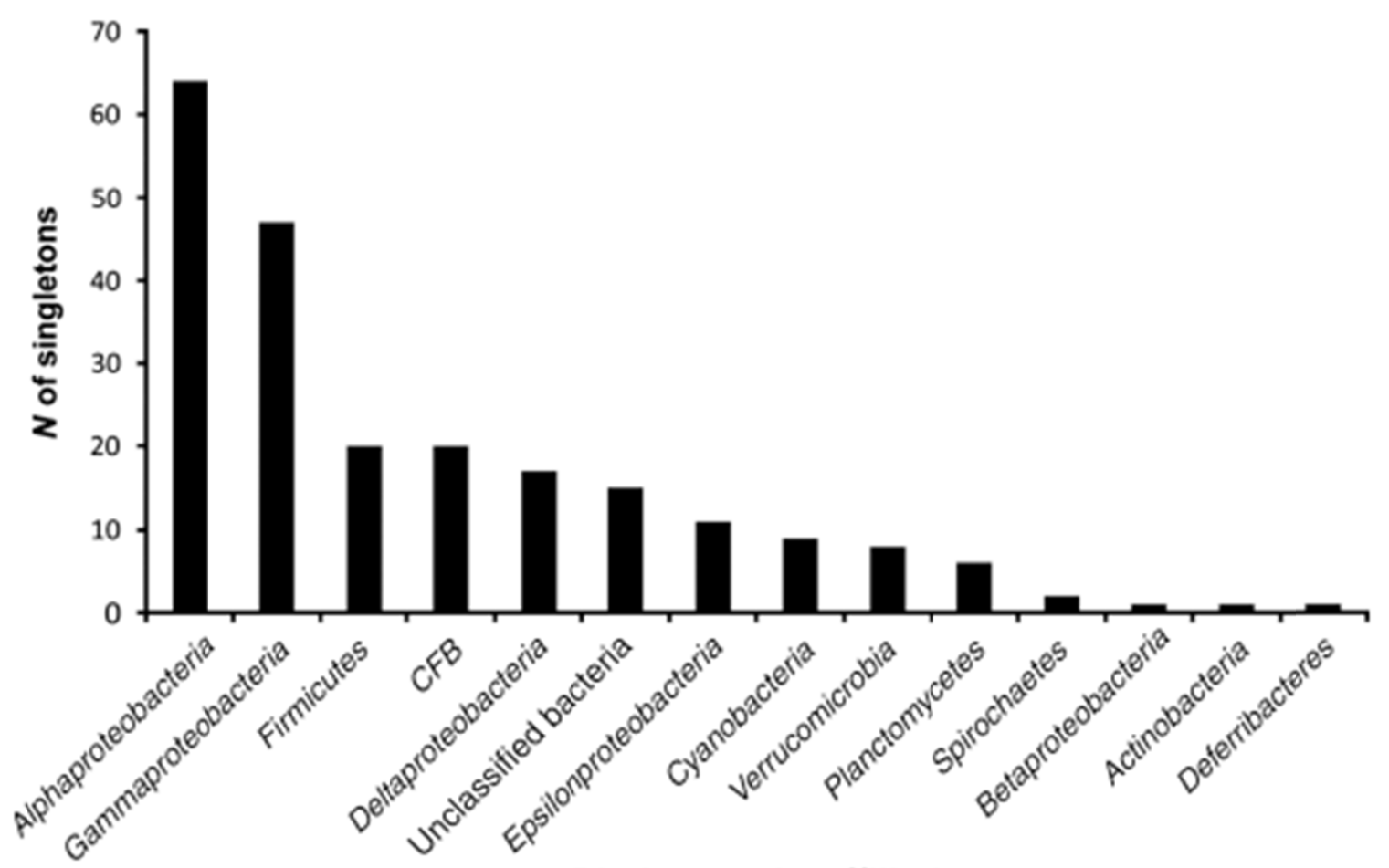

Phylogenetic affiliation 
Figure 3.

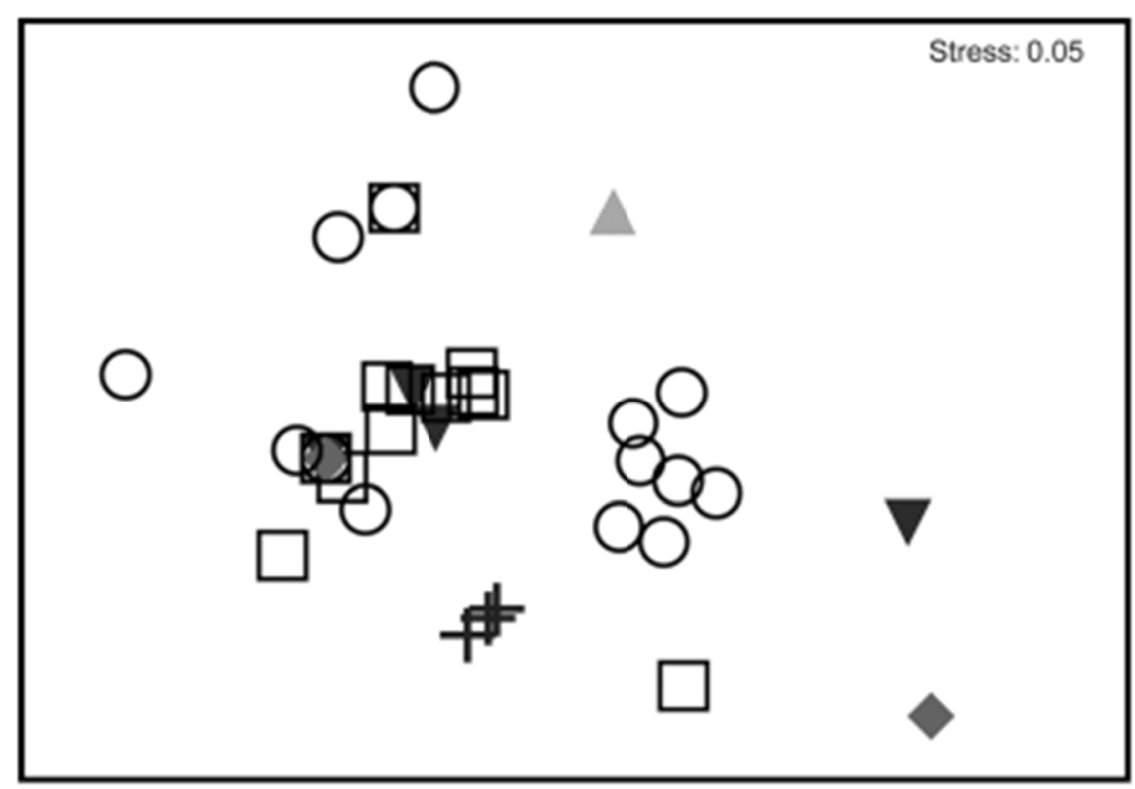

Porites lutea

7 Montastraea annulularis

$\square$ Diploria strigosa

- Montastraea cavernosa

Siderastrea siderea

十 Montipora hispida 
Figure 4.

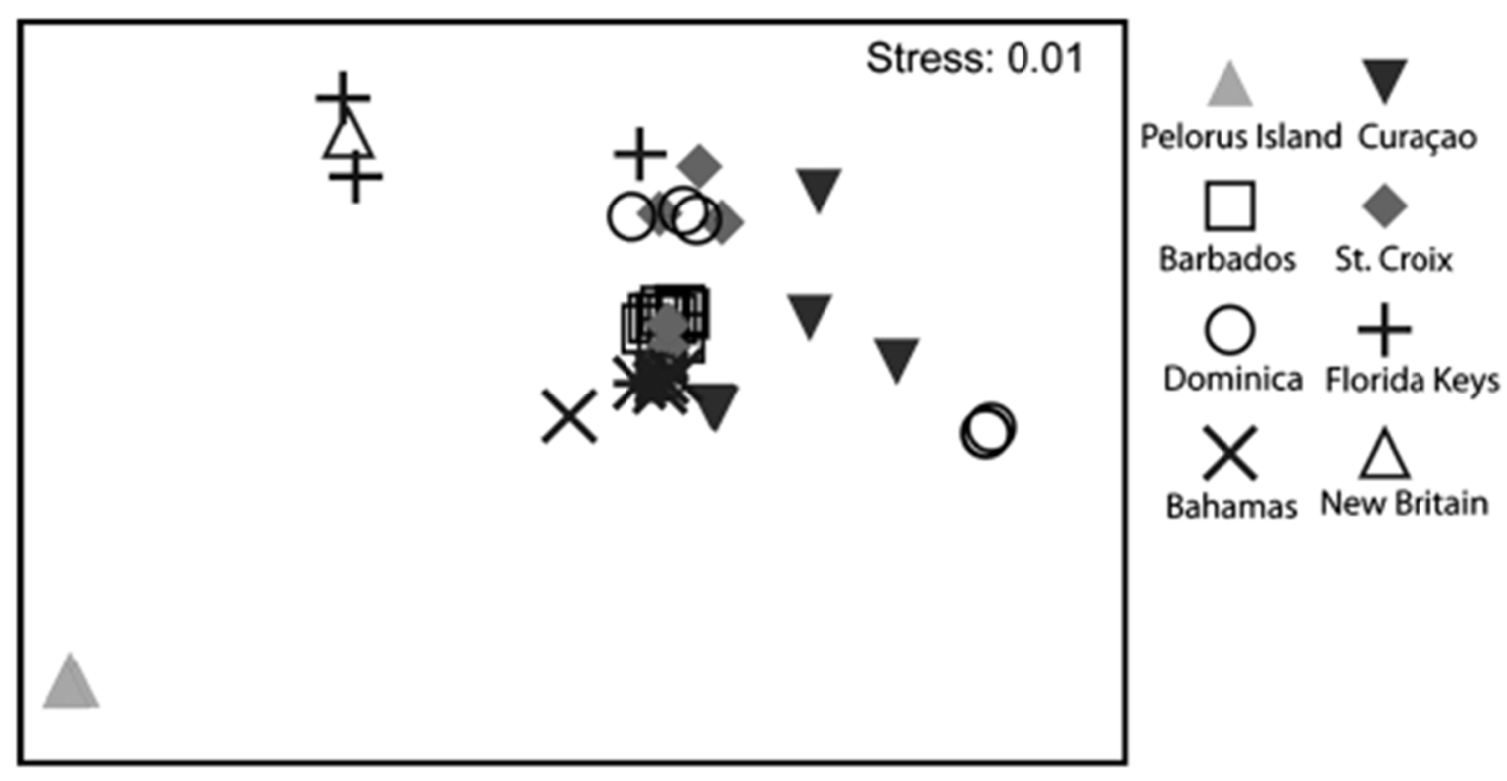


CHAPTER III

FINE-STRUCTURAL ANALYSIS OF BLACK BAND DISEASE-

INFECTED CORAL REVEALS BORING CYANOBACTERIA

AND NOVEL BACTERIA 


\begin{abstract}
Examination of coral fragments infected with black band disease (BBD) at the fine- and ultrastructural levels using scanning (SEM) and transmission electron microscopy (TEM) revealed novel features of the disease. The SEM images of the skeleton from the host coral investigated (Montastraea annularis species complex) revealed extensive boring underneath the BBD mat, with cyanobacterial filaments present within some of the bore holes. Cyanobacteria were observed to penetrate into the overlying coral tissue from within the skeleton and were present throughout the mesoglea between tissue layers (coral epidermis and gastrodermis). A population of novel, as yet unidentified, small filamentous bacteria was found at the leading edge of the migrating band. The population of these bacteria increased in number within the band and was present within degrading coral epithelium, suggesting a role in disease etiology. In coral tissue in front of the leading edge of the band, cyanobacterial filaments were observed to be emerging from bundles of sloughed-off epidermal tissue. Degraded gastrodermis containing actively dividing zooxanthellae was observed using both TEM and SEM. The BBD mat contained cyanobacterial filaments that were twisted, characteristic of negative-tactic responses. Some evidence of boring was found in apparently healthy control coral fragments; however, unlike in BBD-infected fragments, there were no associated cyanobacteria. These results suggest the coral skeleton as a possible source of pathogenic BBD cyanobacteria. Additionally, SEM revealed the presence of a potentially important group of small, filamentous BBD-associated bacteria yet to be identified.
\end{abstract}




\section{INTRODUCTION}

Research into coral diseases over the last 5 decades has revealed a high degree of complexity of those diseases investigated. Many coral diseases exhibit similar signs, such as various disease states referred to collectively as 'white syndrome' (Bythell et al. 2004). Corals may have developed resistance to other coral pathogens, as is the case for the bacterial bleaching pathogen Vibrio shiloii (Rosenberg et al. 2009) and the white plague type II pathogen Aurantimonas coralicida (Richardson \& Aronson 2002). Molecular studies have shown that specific bacterial sequences are present both in apparently healthy corals and in corals with different diseases, with unknown roles in each case (Rypien et al. 2010).

Black band disease (BBD) in particular exemplifies coral disease complexity and has been the subject of microbiological and microscopic investigation since the 1970s (Ducklow \& Mitchell 1979, Rützler et al. 1983, Carlton \& Richardson 1995, Cooney et al. 2002, Frias-Lopez et al. 2002, Barneah et al. 2007, Sekar et al. 2008, Richardson et al. 2009, Sato et al. 2009). It has been known for decades that BBD is characterized by a complex, polymicrobial mat community in which gliding, filamentous cyanobacteria are volumetrically dominant (Rützler \& Santavy 1983). The mat migrates as a welldefined band across apparently healthy coral tissue, leaving behind freshly denuded skeleton, at an average rate of $3 \mathrm{~mm} \mathrm{~d}^{-1}$ (Rützler et al. 1983). The BBD cyanobacteria provide a structural framework within which a diverse microbial community is present (Rützler \& Santavy 1983). While the mechanisms that 
govern the initiation of $\mathrm{BBD}$, as well as its mode of migration and tissue destruction, are still incompletely understood, it has recently been shown that sulfide (produced by BBD-associated sulfate-reducing bacteria) is required for initial infection (Richardson et al. 2009).

Multiple cyanobacterial species have been identified from colonies exhibiting macroscopic signs consistent with BBD infection (Cooney et al. 2002, Frias-Lopez et al. 2003, Sussman et al. 2006, Myers et al. 2007), along with other putative pathogens (Arotsker et al. 2009), which have been reported to be present on non-BBD corals as well (Jones et al. 2004). The natural reservoirs of BBD pathogens have not been elucidated, although different sources have been proposed. Cyanobacteria associated with BBD were detected (on the basis of microscopic observation of characteristic morphology) in sediment-filled depressions on apparently healthy corals (Richardson 1997). However, none of these corals was observed to develop BBD. Molecular studies and disease surveys have also suggested an association with sewage contamination, fish or human pathogens, or terrestrial run-off (Frias-Lopez et al. 2002, Kaczmarsky et al. 2005, Sekar et al. 2008). While BBD has previously been demonstrated to be transmitted by fish (Aeby \& Santavy 2006). Sequences associated with human and fish pathogens were present in fewer than $4 \%$ of the sequences from 84 clone libraries constructed from BBD samples (Miller \& Richardson 2011). Field surveys comparing sewage-impacted and non-impacted sites revealed a higher incidence of BBD-infected colonies around impacted sites (Kaczmarsky et al. 2005). Molecular analysis of BBD samples from these same sites has shown that 
BBD composition differed significantly between impacted and non-impacted sites (Sekar et al. 2008). These results suggest that sewage may provide opportunistic pathogens that could contribute to the disease, and that other factors such as nutrient loading may contribute to the increase in BBD prevalence.

A previous scanning electron microscopy (SEM) study of BBD showed that the BBD consortium consisted of a mixture of filamentous cyanobacteria and sulfide-oxidizing bacteria (Beggiatoa), with spiral bacteria commonly embedded within the consortium (Ducklow \& Mitchell 1979). These authors proposed that BBD pathogens consumed the coral tissue and released zooxanthellae into the disease matrix. It was suggested that cyanobacteria may be necessary to initiate and maintain the disease, but that Beggiatoa present within the mat may be more intimately involved with the disease process due to the finding of cyanobacteria only in natural infections, and of Beggiatoa in both natural and artificial infections. In another BBD study, Rützler et al. (1983) found that in freshly infected coral tissue, bundles of cyanobacterial filaments were often separate from the main population and penetrated into the coral epidermis. These filaments then tunneled in all directions underneath the epidermis. It was suggested that this physical penetration is preceded by chemical degradation, with the mat migrating over the top of the degraded tissue, further degrading it, and resulting in a mat that contained decaying coral tissue (Rützler et al. 1983).

The purpose of the current study was to build upon these previous studies and, using electron microscopy, to examine the relationships between the BBD microbial mat microorganisms and the coral host, including infected and 
apparently healthy tissue and skeleton immediately in front of, underneath, and behind the migrating band. We also describe the condition of the host coral tissue and skeleton and characterize the fine structure of the BBD cyanobacterial matrix (mat fabric).

\section{MATERIALS AND METHODS}

\section{Sample collection}

Seven BBD-infected fragments and two apparently healthy control fragments from eight colonies of the Montastraea annularis species complex were used for this study. Both naturally and artificially infected fragments were utilized. Fragments were infected by placing a small amount of freshly collected BBD mat directly onto the surface of corals (described below). This method results in a migrating BBD infection that lyses coral tissue the same way as BBD in the reef environment (Voss \& Richardson 2006, Richardson et al. 2009).

Of the BBD-infected fragments, two were collected by chiseling fragments from a BBD-infected colony on Algae Reef offshore of Key Largo, Florida (USA). Five other BBD-infected fragments were artificially infected in the laboratory, including four collected from Horseshoe Reef, Lee Stocking Island (LSI), Bahamas, and one from Algae Reef, Key Largo. The bands on the LSI fragments were allowed to migrate for two days prior to fixation, while the band from the Florida Keys migrated for three days. To artificially infect fragments, they were held out of the water, gently abraded with the tip of a needleless syringe containing a BBD sample, and a small amount of the BBD mat was expelled onto the surface of the colony. After $\sim 30 \mathrm{~s}$, the mat was observed to adhere to the 
coral fragment surface, at which time the fragment was placed back into the aquarium. Two uninfected fragments from apparently healthy colonies, both collected at LSI, were used as controls. These fragments were abraded in the same manner, but were not inoculated with the BBD consortium.

\section{Electron microscopy}

Artificially infected coral fragments were prepared for SEM analysis by immersion in $2 \%$ glutaraldehyde in $0.05 \mathrm{M}$ sodium cacodylatebuffered filtered seawater immediately after removal from experimental aquaria. The BBD-infected fragments collected in situ on the reef were placed in $50 \mathrm{ml}$ Falcon tubes (underwater), and immersed in fixative immediately upon return to the boat. In the laboratory, the glutaraldehyde fixative was refreshed, and fragments were transferred to $0.05 \mathrm{M}$ sodium cacodylate filtered seawater buffer ( $3 \mathrm{X}$ for $10 \mathrm{~min}$ each), and post fixed in 1\% osmium tetroxide in buffer for $30 \mathrm{~min}$. After an additional three buffer washes, the fragments were dehydrated in a graded series of ethanol, with a final concentration of $100 \%$. Small subfragments were then chiseled from both naturally and artificially infected fragments at the interface of the BBD mat and apparently healthy tissue for transmission electron microscopy (TEM). The remaining coral fragments were used for SEM, and were dried in hexamethyldisilazane (HMDS) at room temperature to outgas overnight. They were then mounted on carbon adhesive-covered aluminum stubs and coated with palladium. Samples were imaged in an FEI XL-30 ESEM/SEM fitted with an Oxford EDS system. For TEM analysis, the calcified subfragments in 
$100 \%$ ethanol were embedded in Spurr@ embedding resin. A Sorval MT-2 ultramicrotome fitted with a diamond knife was used to cut sections of the coral and skeleton embedded in the blocks. Sections were placed on copper grids and stained with lead citrate (Reynolds 1963). Since calcified material was sectioned, uranyl acetate stain was not used because it is an acidic stain, and would dissolve the sectioned calcium carbonate skeleton, which was a subject of this study. Sections were photographed with a JEOL 1400 TEM equipped with a Gatan digital camera.

\section{Analysis}

The BBD-infected coral tissue and skeleton fragments were examined using an SEM. Areas observed included the black band consortium (surface and interior of the mat), the coral/band interface (leading and trailing edges), exposed coral skeleton (the result of band migration), and apparently healthy areas of coral tissue in front of the band. The leading and trailing edges of the band were determined on the basis of the presence of apparently healthy coral tissue on one side (leading edge), and exposed coral skeleton on the other side (trailing edge) of samples.

\section{RESULTS}

Effects of BBD on the integrity of the coral tissue and skeleton were distinctive. The imaging techniques allowed documentation of relatively intact tissue in the apparently healthy areas of the coral, infiltration of apparently healthy tissue by BBD-associated microorganisms at the band/tissue interface at 
the leading edge of the band, markedly/completely degraded tissue and skeleton at the interface behind the band, and heavily bored exposed coral skeleton left after band migration.

\section{Leading edge of the BBD mat}

At the base of the leading edge of the BBD mat, cyanobacteria were observed actively boring through the coral skeleton into the overlying coral tissue (Fig. 1A). Examination of tissue which had been peeled back from the underlying skeleton (likely an artifact of the sampling/fixation process) revealed the relationship between the cyanobacteria and the coral tissue and skeleton. In Fig. $1 \mathrm{~A}$, numerous cyanobacteria can be seen emerging from within the skeleton and penetrating the overlying tissue. The direction of migration of the cyanobacteria into the overlying tissue is also apparent. Some of the borings observed in the skeleton contained intact cyanobacteria (living at the time of fixation), with some of the filament tips observed to be emerging from the bore holes and broken off in the tissue. Cyanobacteria were also observed migrating between the septae of the coral polyps (Fig. 1B), and appeared to be moving toward the center of the coral polyp. Examination of cross-sections of the cyanobacteria using TEM revealed a radial thylakoid arrangement (Fig. 1C). Filaments were observed to have tapered ends (Fig. 1D), which is characteristic of a cyanobacterium that is the most prevalent cyanobacterium in BBD (Rützler \& Santavy 1983).

Ahead of the migrating band, in an area of apparently healthy, intact coral tissue, small (typically $\sim 0.5 \mu \mathrm{m}$ in width) groups of filamentous bacteria were observed to penetrate the coral tissue through the calicoblastic epithelium, the 
gastrodermis, and the mesoglea (Fig. 2A). Closer to the band, degraded coral tissue, distinguished by vacuolated columnar cells of the epidermis and exposed zooxanthellae on the surface of the gastrodermis, were observed. In these locations, cyanobacterial filaments ( $4 \mu \mathrm{m}$ in width) were observed in the mesoglea (Fig. 2B). Within BBD-infected tissue, cyanobacteria were observed in the gastrodermis, mesoglea, and epidermis (Fig. 2C). The migration of the relatively large cyanobacteria through the mesoglea appeared to assist in the degradation and separation of the coral tissue. Greater numbers of cyanobacteria were observed underneath the coral tissues just ahead of the well defined mat (Fig. 2D). In this image, the BBD mat, consisting primarily of cyanobacteria, can be seen behind the coral tissue. Cyanobacteria were commonly seen underneath apparently healthy tissue up to several millimeters ahead of the advancing band.

Fine-structure of the BBD mat and infected coral tissue Relatively large populations of cyanobacteria were observed in coral tissue layers associated with the advancing front of the band (Fig. 3A). In this figure, significant degradation of the coral tissue is visible, apparent from extracellular zooxanthellae in the background, and the lack of intact coral tissue. The thin filamentous microbes observed to be infiltrating intact tissue in the apparently healthy area in front of the band (Fig. 2A) were intermixed with the cyanobacterial filaments in the leading edge of the band. In some cases, these thin filamentous microbes were associated with the breakdown of the coral 
epidermis (Fig. 3B). The gastrodermis also exhibited some degradation, and extracellular zooxanthellae were exposed.

In some areas, the epidermis was separated from the gastrodermis and appeared to be sloughed off, forming rolled bundles ahead of the migrating band. The formation of bundles ahead of the well-defined mat is likely the result of the fact that the healthy epidermis in front of the advancing band is anchored to the rest of the coral tissue (Fig. 3C). In some cases, abundant rolled up epidermal bundles were present, found $<1$ to $2.5 \mathrm{~mm}$ ahead of the advancing band. These tissue bundles could be identified as epidermal tissue based on the characteristic intact columnar cells typical of this tissue type (Fig. 3D).

Because of the migration of the cyanobacteria through the mesoglea into the epidermal tissue, the sloughed-off epidermal bundles were infiltrated with cyanobacterial filaments, which were observed to emerge from the bundles (Fig. 4A). The emergence of the cyanobacteria from the epidermal bundles resulted in large numbers of cyanobacteria millimeters ahead of the advancing band.

Small pellet-like structures appeared to form from further degradation of the bundles of epidermis. These structures, which ranged from 15 to $25 \mu \mathrm{m}$ wide and 50 to $90 \mu \mathrm{m}$ long, were commonly present within the BBD mat (Fig. 4B) and were pervasive in all of the infected fragments. Obvious throughout the mat was a distinct exopolysaccharide (EPS) layer associated with the cyanobacterial filaments (Fig. 4C). Examination of intracellular zooxanthellae within BBDinfected tissues using TEM revealed organelle ultrastructure typical of normal cells. These cells were often observed as doublets, indicative of active cell 
division (Fig. 4D). Apparently healthy extracellular zooxanthellae were also present (Fig. 5B).

\section{Microbiological aspects of the disease process}

While the overall BBD consortium was clearly dominated by filamentous cyanobacteria, numerous other, smaller, associated bacteria were observed (Fig. $5 \mathrm{~A})$ to dominate in some microenvironments of the band. These populations of smaller bacteria included filamentous, rod- and coccoid-shaped morphotypes (Figs. 4B \& 5A). The latter image exhibits an area in which the BBD mat overlay exposed coral skeleton and no coral tissue remained. This area contained fewer cyanobacteria, and the smaller bacteria were present as a biofilm at the base of the band. Since the overall biomass of these microbes was minimal compared to the cyanobacteria, they were a much less conspicuous component of the mat overall. However, they appeared to be important in the final breakdown of the coral tissue. Although rod- and coccoid-shaped bacteria were present throughout all areas of the infected fragments, the area left behind after mat migration contained a much greater number of these microbes (Fig. 5A). Degraded tissue was evident in other areas of the trailing end of the mat where zooxanthellae were observed to be present among different filamentous BBD microorganisms (Fig. 5B). In this image, the gastrodermis was completely degraded and the well-defined band overlay exposed coral skeleton.

Filaments among the BBD consortium were often observed to be intertwined, twisted, and had formed loops (Fig. 5C), particularly at the edges of 
the BBD mat. In some cases, distinct holes were formed within the BBD mat due to the intertwining of several cyanobacterial filaments (Fig. 5D).

Boring activity by the cyanobacteria (Fig. 1A) led to the severe degradation of the coral skeleton, such that numerous bore holes and tracks were present in the exposed skeleton left behind by the migrating band (Fig. 6A). These areas were generally observed in large clusters present on the surface of the exposed skeleton. In addition to the euendolithic cyanobacteria occupying the bored holes (Fig. 1C), numerous chasmoendolithic bacteria were observed (Fig. $6 B)$.

The tissue of the apparently healthy coral (control) fragments was intact (Fig. 6C) and overlay skeleton that exhibited no visible degradation or microbial infiltration comparable to that seen in the BBD-infected coral fragments. While the skeleton of the healthy coral fragment did exhibit borings and tracks that were morphologically similar to those of the infected fragments (Fig. 6D), they were far fewer in number. No cyanobacterial filaments were observed on the coral surface or in the borings of healthy fragments, in contrast to the skeleton of BBD-infected fragments.

\section{DISCUSSION}

Evidence of cyanobacterial boring in $B B D$

Our results show that cyanobacteria within the BBD infections examined here are significant borers into and within the coral skeleton, and that these cyanobacteria penetrate into coral tissue from the underlying coral skeleton (Fig. 1A). While the penetration of BBD cyanobacteria into coral tissue has been 
reported previously (Rützler et al. 1983, Barneah et al. 2007, Sato et al. 2009), this is the first observation of BBD cyanobacteria boring into host coral skeleton. This boring behavior is similar to skeletal eroding band, coral disease in the IndoPacific that macroscopically appears very similar to BBD, and in which a sessile folliculinid ciliate (Halofolliculina corallasia) directly invades the coral skeleton and in some cases leads to progressive tissue loss (Page \& Willis 2008).

It is well known that boring cyanobacteria make up a significant component of the coral endolithic community, although prior to the current study none have been associated with disease (Le Campion-Alsumard et al. 1995, Radtke et al. 1997, Perry 1998, Vogel et al. 2000, Tribollet \& Payri 2001, Tribollet 2008). In our study, cyanobacterial borings were generally found in large clusters unevenly distributed throughout the exposed coral skeleton of coral fragments infected with BBD (Fig. 6A). Significant boring was observed both in the artificially infected fragments, which were infected for a period of two to three days, and naturally occurring diseased colonies with an unknown infection period. There was evidence of boring in the apparently healthy (uninfected) control samples, but it was minimal. This suggests that cyanobacteria present within the band exhibit boring behavior throughout the disease process, and not just as they emerge from within the skeleton. The typical rate of boring is likely slower than the advancement of the disease. However, it is difficult to assess boring rates, and to our knowledge previous studies have only estimated rates of bioerosion from boring $\left(\mathrm{g} \mathrm{CaCO}_{3}\right.$ removed), not boring rates. 
The SEM imagery revealed that most of the boring was oriented perpendicular to the coral surface. Boring of carbonates by other cyanobacteria is typically perpendicular rather than parallel to the substrate (Garcia-Pichel 2006). Vertical boring is conducive to a model in which cyanobacteria leave a bore hole as the mat passes overhead and the cyanobacteria are recruited to the mat, or conversely bore into the skeleton from the mat. While horizontal boring would likely require additional boring through the substrate, and the majority of the boring observed in this study was perpendicular to the substrate, tracks were also observed in coral skeleton that were a result of parallel boring (Fig. 6A).

\section{Detection of a novel population of BBD microorganisms}

Scanning electron microscopy revealed consistent populations of small, filamentous microorganisms present within the BBD community. Identification of the taxonomic affiliation of these microorganisms was outside of the scope of this study, but should be targeted in the future. Observation of their presence in association with BBD provides some insight into the disease process. The thin, filamentous microbes were present in the apparently healthy area of the coral tissue immediately in front of the band (Fig. 2A), as well as within the cyanobacterial BBD matrix (Figs. 3A \& 4B), and in degrading epidermal tissue (Fig. 3B). Based on these observations, these bacteria may be important in the initial breakdown of coral tissue, and may also facilitate the penetration of apparently healthy coral tissue by the much larger cyanobacteria. 


\section{Insights into the $B B D$ process}

Scanning electron microscopy was useful in characterizing the role of BBD cyanobacteria in the disease process in terms of both infection of apparently healthy coral tissue and breakdown of tissue. In some cases, migration of cyanobacteria across the infected coral caused the epidermis to be completely removed, and in others, the penetration of cyanobacteria through the mesoglea and epidermis appeared to cause the epidermis to slough off in bundles which were packed with cyanobacterial filaments. Within the mat cyanobacteria could be seen as closely associated with extracellular polysaccharide. Such EPS is characteristic of a large number of mat-forming bacteria, including cyanobacteria (Wingender et al. 1999, Wolfaardt et al. 1999), and serves as a protective barrier to the external environment (De Philippis \& Vincenzini 1998).

It has been proposed that the physical penetration of coral tissue by BBD cyanobacteria is likely to be preceded and greatly aided by chemical lysis (Rützler et al. 1983). It is now known that the chemical microenvironment of the BBD mat is supersaturated with oxygen during the day near the surface, due to photosynthetic activity of the cyanobacteria, and anoxic deeper in the band where sulfide is present (Carlton \& Richardson 1995). At night, when photosynthesis ceases, the oxygen/sulfide interface migrates vertically outward into the overlying water column, rendering the entire mat anoxic and sulfide rich. It has also been determined experimentally that exposure of corals to sulfide at a concentration present in the mat results in lysis of coral tissue within $17 \mathrm{~h}$ (Richardson et al. 1997). Microcystin, a cyanotoxin, has been detected in BBD 
and is produced by BBD-associated cyanobacteria in culture in the laboratory (Richardson et al. 2007, Gantar et al. 2009). It has recently been shown that exposure of healthy coral fragments to purified microcystin causes severe degradation of the epidermis and gastrodermis of corals over a similar timeframe, an effect which is exacerbated in combination with exposure to sulfide (Richardson et al. 2009). The degradation of the epidermis and gastrodermis in BBD-infected fragments in the current study appears to be very similar to that of tissue degraded by exposure to microcystin and sulfide (Richardson et al. 2009), which supports the hypothesis of chemical degradation put forth by Rützler et al. (1983). However, it has been shown that not all BBD infections produce microcystin (Glas et al. 2010), adding to the complexity of this disease.

The observation of intact, dividing zooxanthellae within the BBD cyanobacterial matrix suggests that they too may be affected by the sulfidic and potentially toxic BBD environment. Active zooxanthellae division and expulsion have previously been documented in corals exposed to cyanide (Cervino et al. 2003), suggesting that the zooxanthellae observed in the present study may be undergoing similar stress levels related to exposure to the chemical microenvironment within the disease band.

Epidermal tissue bundles observed during disease progression were always present ahead of the well-defined band. The presence of these bundles was likely a result of the fact that the invaded tissue was contiguous with the apparently healthy tissue in front of the band (Fig. 3C). Cyanobacteria could be seen emerging from these bundles, ahead of the forward edge of the mat. Large 
pellets (Fig. 4B), pervasive throughout all of the BBD samples, were likely the remnants of the epidermal bundles, a result of progressive degradation as the BBD mat passed over them.

The motility patterns exhibited by the BBD cyanobacteria are typical of other cyanobacterial and filamentous bacterial mats. For example, the twisting of filaments and formation of loops found in the band is indicative of negative taxis in gliding, filamentous microorganisms (Møller et al. 1985). In the current study, the twisting of filaments occurred at the edges of the cyanobacteria-dominated mat, suggesting that a chemical or light gradient determined the mat-forming behavior of the BBD cyanobacteria. In addition, the parallel migration of cyanobacterial filaments in the BBD mat suggests a migration toward or away from an environmental cue.

Filamentous, mat-forming cyanobacteria generally do not tolerate high light levels, and self-shade or migrate to light levels more attuned to their lightsaturated photosynthetic rate (Pmax) (Castenholz 1982, Castenholz et al. 1991, Garcia-Pichel et al. 1994). It has been demonstrated that the cyanobacterial population, which exhibits a dark red-black color and is normally on the surface of BBD (and the reason for the name of the disease), moves down into the mat during high light levels and is replaced on the surface by a population of white, gliding, sulfide-oxidizing BBD microorganisms (Beggiatoa sp.) (Richardson 1996, Viehman \& Richardson 2002). This is the opposite of cyanobacterial/Beggiatoa vertical migrations in other sulfide-rich, 
illuminated microbial mats (Jørgensen et al. 1979, Jørgensen 1982). It may be that BBD cyanobacteria at the front of the band migrate into the tissue to attain optimal (relatively lower) light levels, which is consistent with this and a previous study that found cyanobacteria tunneling in a parallel configuration beneath the epidermis ahead of the mat (Rützler et al. 1983). In another study, it was found that two cyanobacterial isolates from BBD, Geitlerinema sp. and Leptolyngbya sp., attained Pmax at relatively low light levels of 81 and $108 \mu \mathrm{E}$ m-2, respectively (Myers et al. 2007). It has also been shown in situ that cyanobacterial migration down into the mat occurs when light levels reach 238 $\mu \mathrm{E} \mathrm{m} \mathrm{m}^{-2} \mathrm{~s}^{-1}$ (Viehman \& Richardson 2002). This discussion does not rule out the possibility that chemotaxis may play a role in migration, an aspect of BBD etiology that is completely unknown.

Not clear from the current analysis is whether the well-defined migrating band follows the pioneering groups of cyanobacteria, or whether the advancement of the band is the result of a high turnover rate of the consortium based on rapid growth of the advancing filaments. In addition, it is also not known whether a large number of cyanobacteria from the main band die or retreat into the coral skeleton by boring activity. The observed behavior of migration toward the gastrovascular cavity through the polyp suggests that retreat into the skeleton during the disease process occurs to some extent. The boring behavior of the cyanobacteria may provide a significant advantage in that the coral skeleton may serve as a reservoir of pathogenic cyanobacteria that persist in low numbers even as disease signs disappear in cooler seasons. 
When more favorable (warmer) conditions resume, the cyanobacterial numbers may again increase and reinfect the coral. Such reoccurrence of BBD on the same corals in subsequent disease seasons has been observed previously (Kuta \& Richardson 1997, Sato et al. 2009). It is likely that both the advancement of the intact band following the pioneering cyanobacteria and the retreat or die-off of some filaments occur to some extent.

\section{Coral skeleton as a reservoir for BBD cyanobacteria}

The hypothesis that the coral skeleton harbors a reservoir of cyanobacteria associated with BBD could be tested by comparing the endolithic cyanobacterial community of BBD-infected corals to the cyanobacterial community in the BBD infection, and to that of the endolithic community of apparently healthy coral colonies using both molecular and culturing techniques. Sampling the same corals in both disease and non-disease seasons would be necessary for this. If the coral skeleton harbored the cyanobacteria associated with BBD, it is expected that the endolithic community should have similar cyanobacteria to the BBD community.

Sato et al. (2009) found that non-BBD cyanobacterial patches that were present on some coral colonies occasionally ( $19 \%$ of the time) shifted from a Blenothrix sp.- dominated mat to a mat dominated by the most prevalent cyanobacterium found globally in BBD, most closely related to Oscillatoria. It is possible that the transition from cyanobacterial patches to BBD was based on movement of BBD cyanobacteria from host skeletal reservoirs, resulting in replacement of Blenothrix sp. as the dominant cyanobacterium. 


\section{SUMMARY}

Black band disease is one of the first coral diseases reported and is considered among the most ecologically important diseases affecting coral reefs. We now know that it consists of a highly variable, complex consortium of microbes. While the mechanisms behind the infection process and pathobiology of BBD are still not completely understood, the results of the current analysis introduce several new insights into this disease. First, the filamentous, gliding cyanobacteria that are associated with the disease actively bore through both the host coral skeleton and tissue, indicating a potential natural reservoir of the

disease. Second, coral tissue lysis and degradation appear to be aided by the physical movement of cyanobacteria through the tissue layers in front of the migrating band. Finally, a novel population of small, as yet unidentified, filamentous bacteria was observed throughout (before, within, and behind) BBD. The presence of these bacteria throughout the disease, including in actively degrading epidermis, suggests that this population may be important in the complete lysis and removal of coral tissue characteristic of this coral disease.

\section{ACKNOWLEDGMENTS}

We thank J. Voss and S. Edge for their help in providing samples for this analysis as well as the Perry Institute for Marine Science, which provided access to the research station in Lee Stocking Island, Bahamas. Sample collection in the Florida Keys National Marine Sanctuary was conducted under permit number FKNMS-2007-026, and at Lee Stocking Island, Bahamas, under permit number CMRC-04- PRJV-01-04C. J. Prince kindly allowed us use of the TEM 
in the Biology Department at the University of Miami. This is contribution number 192 from the Tropical Biology Program at Florida International University, previously published in the journal Diseases of Aquatic Organisms. 


\section{REFERENCES}

1. Aeby G, Santavy D (2006). Factors affecting susceptibility of the coral Montastraea faveolata to black band disease. Mar Eco Prog Ser 318: 103110.

2. Arotsker L, Siboni N, Ben-Dov E, Kramarsky-Winter E, Loya Y, Kushmaro A (2009). Vibrio sp. as a potentially important member of the Black Band Disease consortium in Favia sp. corals. FEMS Microbio Eco 70(3): 515524.

3. Antonius A (1981). The "Band" Diseases in Coral Reefs. Proc 4th Int Coral Reef Symp_2: 3-6.

4. Barneah O, Ben-Dov E, Kramarsky-Winter E, Kushmaro A (2007). Characterization of black band disease in Red Sea stony corals. Environ Microbio 9(8): 1995-2006.

5. Carlton RG, Richardson LL (1995). Oxygen and sulfide dynamics in a horizontally migrating cyanobacterial mat: black band disease of corals. FEMS Microbio Eco 18: 155-162.

6. Castenholz RW (1982). Motility and taxes. In: N.G. Carr and B.A. Whitten (ed)_Biology of cyanobacteria. Blackwell Scientific Publications, Ltd., Oxford, United Kingdom: 414-439.

7. Castenholz RW, Jørgensen BB, D'Amelio E, Bauld J (1991). Photosynthetic and behavioral versatility of the cyanobacterium Oscillatoria boryana in sulfide-rich microbial mat. FEMS Microbio Eco 86: 43-48.

8. Cervino JM, Hayes RL, Honovich M, Goreau TJ, Jones S, Rubec PJ (2003). Changes in zooxanthellae density, morphology, and mitotic index in hermatypic corals and anemones exposed to cyanide. Mar Poll Bul. 46: $573-586$.

9. Cooney R, Pantos M, Le Tissier M, Rarer A, O'Donnell A, Bythell J (2002). Characterization of the bacterial consortium associated with black band disease in coral using molecular microbiological techniques. Environ Microbio 4: 401-413.

10. De Phillippis R, Vincenzini M (1998). Exocellular polysaccharides from cyanobacteria and their possible applications. FEMS Microbiology Review 22: $151-175$. 
11. Ducklow H, Mitchell R (1979). Observations on naturally and artificially diseased tropical corals: A scanning electron microscope study. Microb Ecol 5: 215-223.

12. Dustan P (1977). Vitality of reef coral populations off Key Largo, Florida: recruitment and mortality. Environ Geol 2: 51-58.

13. Frias-Lopez J, Zerkle A, Bonheyo G, Fouke B (2002). Partitioning of bacterial communities between seawater and healthy, black band diseased, and dead coral surfaces. Appl and Environ Microbio: 2214-2228.

14. Frias-Lopez J, Bonheyo G, Qusheng J, Fouke B (2003). Cyanobacteria associated with coral black band disease in Caribbean and Indo-Pacific reefs. Appl and Environ Microbiol 69: 2409-2413.

15. Gantar M, Sekar R, Richardson LL (2009). Toxicity of culturable cyanobacteria associated with black band disease of corals. Micro Eco 58: 856-864.

16. Garcia-Pichel F, Mechling M, Castenholz RW (1994). Diel migrations of microorganisms within a benthic, hypersaline mat community. Appl and Environ Microbio 60: 1500-1511.

17. Garcia-Pichel F (2006). Plausible mechanisms for the boring on carbonates by microbial phototrophs. Sediment Geo: 205-213.

18. Glas M, Motti C, Negri A, Sato Y, Froscio S, Humpage A, Krock B, Cembella A, Bourne D (2010). Cyanotoxins are not implicated in the etiology of coral black band disease outbreaks on Pelorus Island, Great Barrier Reef. FEMS Microbio Eco 73(1): 1-12.

19. Jones RJ, Bowyer J, Hoegh-Guldberg O, Blackall LL (2004). Dynamics of a temperature-related coral disease outbreak. Mar Eco Prog Ser 281: 6377.

20. Jørgenson BR, Blackburn TH, Cohen Y (1979). Diurnal cycle of oxygen and sulfide microgradients and microbial photosynthesis in a cyanobacterial mat sediment. Appl and Environ Microb 38: 46-58.

21. Jørgenson, B (1982). Ecology of the bacteria of the sulfur cycle with special reference to anoxic-oxic interface environments. Philos Trans $R$ Soc Lond B 298: 543-561. 
22. Kaczmarsky L, Draud M, Williams E (2005). Is there a relationship between proximity to sewage effluent and the prevalence of coral disease? Carrib J of Science 41(1): 124-137.

23. Kuta K, Richardson LL (1997). Fate of black band diseased corals in the Florida Keys. Proc 8th Int Coral Reef Symp 1: 575-578.

24. Le Campion-Alsumard T, Golubic S, Hutchings $P$ (1995). Microbial endoliths in skeletons of live and dead corals: Porites lobata. Mar Eco Prog Ser 117: 149-157.

25. Møller M, Nielsen L, Jørgensen B (1985). Oxygen responses and mat formation by Beggiatoa spp. Appl and Environ Microb 50(2): 373-382.

26. Myers J, Richardson LL, Sekar R (2007). Molecular detection and ecological significance of the cyanobacteria Geitlerinema and Leptolyngbya in black band disease of corals. Appl and Environ Microbio 73: 5173-5182.

27. Page CA, Willis BL (2008). Epidemiology of skeletal eroding band on the Great Barrier Reef and the role of injury in the initiation of this widespread coral disease. Coral Reefs 27(2): 257-272.

28. Perry C (1998). Grain susceptibility to the effects of microboring: implication for the preservation of skeletal carbonates. Sedimentology 45: 39-51.

29. Radtke G, Le Campion-Alsumard T, Golubic S (1997). Microbial assemblages involved in tropical coastal bioerosion: an Atlantic-Pacific comparison. Proc 8th Int Coral Reef Symp, Panama 2: 1825-1830.

30. Reynolds ES (1963). The use of lead citrate at high $\mathrm{pH}$ as an electronopaque stain in electron microscopy. J of Cell Biol 17: 208-212.

31. Richardson LL (1996). Horizontal and vertical migration patterns of Phormidium corallyticum and Beggiatoa spp. associated with black band disease of corals. Micro Eco 32: 323-335.

32. Richardson LL (1997). Occurence of the black band disease cyanobacterium on healthy corals of the Florida Keys. Bull of Mar Sci 61(2): 485-490.

33. Richardson LL, Aronson R (2002). Infectious diseases of reef corals. Proc of the 9th Int Coral Reef Symp 2: 1225-1230. 
34. Richardson LL, Kuta K, Schnell S, Carlton R (1997). Ecology of the black band disease microbial consortium. Proc 8th Int Coral Reef Symp: 597600.

35. Richardson LL, Goldberg WM, Carlton RG, Halas JC (1998). Coral disease outbreak in the Florida Keys: Plague type II. Revista de Biología Tropical 46: 187-198.

36. Richardson LL, Smith GW (2001). Integrating microbiological, microsensor, physiologic and molecular techniques in the study of coral disease pathogenesis. Hydrobiologia 460: 71-89.

37. Richardson LL, Sekar R, Myers J, Gantar M, Voss J, Kaczmarsky L, Remily E, Boyer G, Zimba P (2007). The presence of the cyanobacterial toxin microcystin in black band disease of corals. FEMS Microbio Eco 272(2): 182-187.

38. Richardson LL, Miller A, Broderick E, Kaczmarsky L, Gantar M, Stanic D, Sekar R (2009). Sulfide, microcystin, and the etiology of black band disease. Dis Aquat Organ 87: 79-90.

39. Rosenberg E, Kushmaro A, Kramarsky-Winter E, Banin E, Loya Y (2009). The role of microorganisms in coral bleaching. ISME J 3: 139-146.

40. Rützler K, Santavy D (1983). The black band disease of Atlantic reef corals. PSZNI Mar Eco 4: 301-319.

41. Rützler K, Santavy D, Antonius A (1983). The black band disease of Atlantic reef corals III: Distribution, Ecology, and Development. Mar Eco 4(44): 329-358.

42. Rypien KL, Ward JR, Azam F (2010). Antagonistic interactions among coral-associated bacteria. Environ Microbio 12: 28-39.

43. Sato $Y$, Willis BL, Bourne DG (2009). Successional changes in bacterial communities during the development of black band disease on the reef coral, Montipora hispida. Int S for Micro Eco 1-12.

44. Sekar R, Kaczmarsky LT, Richardson LL (2008). Microbial community composition of black band disease on the coral host Siderastrea siderea from three regions of the wider Caribbean. Mar Eco Prog Ser 362: 85-98.

45. Sussman M, Bourne DG, Willis BL (2006). A single cyanobacterial ribotype is associated with both red and black bands on diseased corals from Palau. Dis of Aquat Organ 69: 111-118. 
46. Taylor D (1983). The black band disease of Atlantic reef corals. II. Isolation, cultivation, and growth of Phormidium corallyticum. PSZNI: Mar Eco 4: 320-328.

47. Tribollet A, Payri $C$ (2001). Bioerosion of the crustose coralline alga Hydrolithon onkodes by microborers in the coral reefs of Moorea, French Polynesia. Oceanolog Acta 24: 329-342.

48. Tribollet A (2008). The boring microflora in modern coral reef ecosystems: a review of its roles. Current developments in bioerosion: 67-94.

49. Viehman TS, Richardson LL (2002). Motility patterns of Beggiatoa and Phormidium corallyticum in black band disease. Proc 9th Int Coral Reef Symp: 1251-1255.

50. Viehman TS, Mills DK, Meichel GW, Richardson, LL (2006). Culture and identification of Desulfovibrio spp. from black band disease of corals on reefs of Florida Keys and Dominica. Dis Aquat Organ 69: 119-127.

51. Vogel K, Gektidis M, Golubic S, Kiene WE, Radtke G (2000).

Experimental studies on microbial bioerosion at Lee Stocking Island, Bahamas, and One Tree Island, Great Barrier Reef, Australia: implications for paleoecological reconstructions. Lethaia: Int J of Palaeo and Stratig 33(3): 190-204.

52. Voss J, Richardson LL (2006). Nutrient enrichment enhances black band disease progression in corals. Coral Reefs 25: 569-576.

53. Wingender J, Neu T, Flemming $\mathrm{H}$ (1999). What are bacterial extrcellular polymeric substances? Microbial Extracellular Polymeric Substances, Springer: 1-19.

54. Wolfaardt G, Lawerence J, Korber D (1999). Function of EPS. Microbial Extracellular Polymeric Substances, Springer: 171-200. 


\section{FIGURE LEGENDS}

Figure 1. SEM ( $A$ and $B)$ and TEM images $(C$ and $D)$ of BBD-infected fragments at the leading edge of the BBD mat. A. Cyanobacteria emerging from within the coral skeleton. Circle (bottom right) of the micrograph indicates the tip of a cyanobacterium emerging from the skeleton. Circle (top left) indicates a partial (broken) filament inside the coral tissue. B. Cyanobacteria migrating in between the septae of the coral polyp. Arrows indicate the direction of movement. C. Cross-section of cyanobacteria in the BBD mat showing the thyllakoid arrangement of the filaments. D. Longitudinal section of cyanobacterial filaments in the BBD mat showing the characteristic tapered end. Ti: Coral tissue; Cy: Cyanobacteria; Sk: Coral skeleton; Po: Coral polyp; Bb: Black band; Th: Thylakoids.

Figure 2. SEM (A, B, and D) and TEM image (C) images of BBD-infected coral fragments at the leading edge of the BBD mat. A. Filamentous bacteria in the epithelium, mesoglea, and gastrodermis preceding the main band. Arrows indicate filaments. Circle encloses filaments in the mesoglea.

B. Cyanobacterium present in the mesoglea and epithelium. C. Cyanobacteria in the gastrodermis, mesoglea, and epithelium. D. Cyanobacteria migrating underneath coral tissue ahead of the main band (circled in background). Ep: Epidermis; Gd: Gastrodermis; Ce: Calicoblastic epithelium; Ms: Mesoglea; Zo: Zooxanthellae; Cy: Cyanobacteria; Tf: Thin, filamentous microbes. 
Figure 3. SEM images of the interface of the BBD mat and apparently healthy tissue. A. Cyanobacteria and thin filamentous bacteria migrating underneath the coral epidermis. B. Degrading coral epidermis with thin filamentous microbes. C. Sloughed off bundles of epithelium ahead of the migrating band. D. Close-up of a break in one of the epidermal bundles. Zo: Zooxanthellae; Tf: Thin, filamentous microbes; Cy: Cyanobacteria; Bb: Black band; Ti: Coral tissue; Ep: Coral epidermis; Po: Coral polyp; Bu: Epidermal bundle Cc: Columnar cell

Figure 4. SEM (A, B, and C) and TEM (D) images of the BBD mat at the interface near the front $(A)$ and middle $(B, C$, and $D)$ of the band. A. Cyanobacteria emerging from within a sloughed off epidermal bundle. B. The black band mat containing cyanobacteria, thin filamentous bacteria, and small pellets of debris. C. Cyanobacteria moving in parallel through a distinct exo-polysaccharide layer. Filaments can be seen migrating on top of and through the EPS layer. D. TEM section near the interface of the well-defined band and the exposed coral skeleton of actively dividing zooxanthellae within the BBD-infected tissues as indicated by the high number of dividing cells (doublets). Cy: Cyanobacteria; Eps: Exo-polysaccharide layer; Tf: Thin, filamentous microbes Db: Zooxanthellae doublet; Zo: Zooxanthellae; Bu: Epidermal bundle; Pe: Pellet.

Figure 5. SEM images near the back of the band ( $B$ and $D)$ and at the interface between the BBD mat and the exposed coral skeleton ( $A$ and $C$ ). A. Numerous non-filamentous bacteria associated with cyanobacterial filaments in the BBD 
mat. B. Zooxanthellae among the BBD mat cyanobacteria in the degraded gastrodermis. Dark arrows indicate potential filamentous sulfide-oxidizing bacteria and light arrows indicate cyanobacteria. C. Twisting of cyanobacterial filaments creating loops at the periphery of the mat. D. A distinct hole of intertwined cyanobacterial filaments within the BBD mat. Cy: Cyanobacteria; Zo: Zooxanthellae; Sk: Coral skeleton.

Figure 6. SEM images comparing the exposed coral skeletons of a BBD-infected fragment behind the mat ( $A$ and $B$ ) and of an apparently healthy coral ( $C$ and $D)$. A. Bore holes in the exposed coral skeleton. B. Bore hole occupied by a chasmoendolithic filamentous bacterium. C. Apparently healthy coral fragment exhibiting intact coral tissue overlying the coral skeleton. D. Bore holes and tracks present on the surface of apparently healthy coral skeleton. Sk: Coral skeleton; Ce: Chasmoendolith; Ht: Healthy tissue. 
Figure 1.
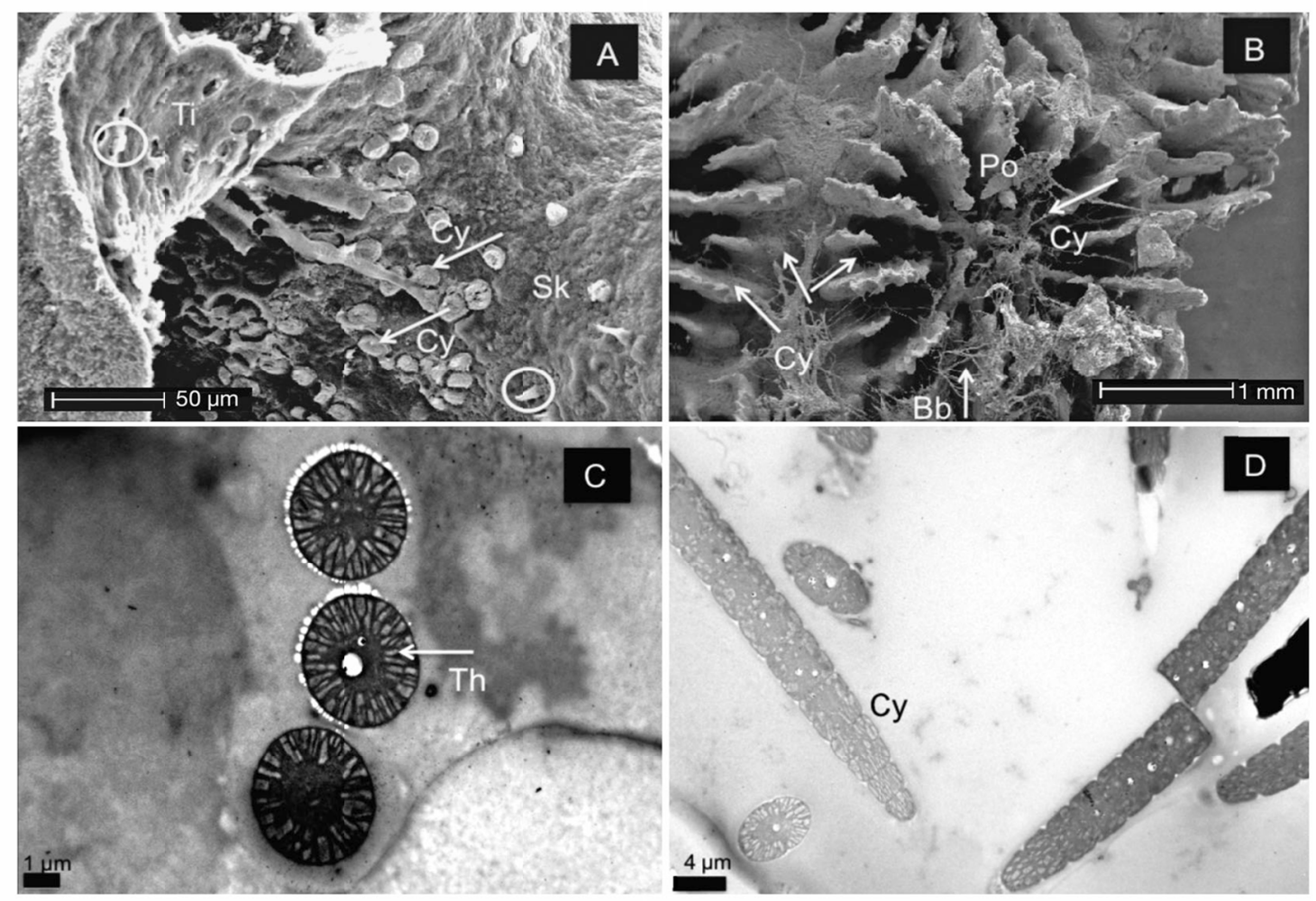
Figure 2.
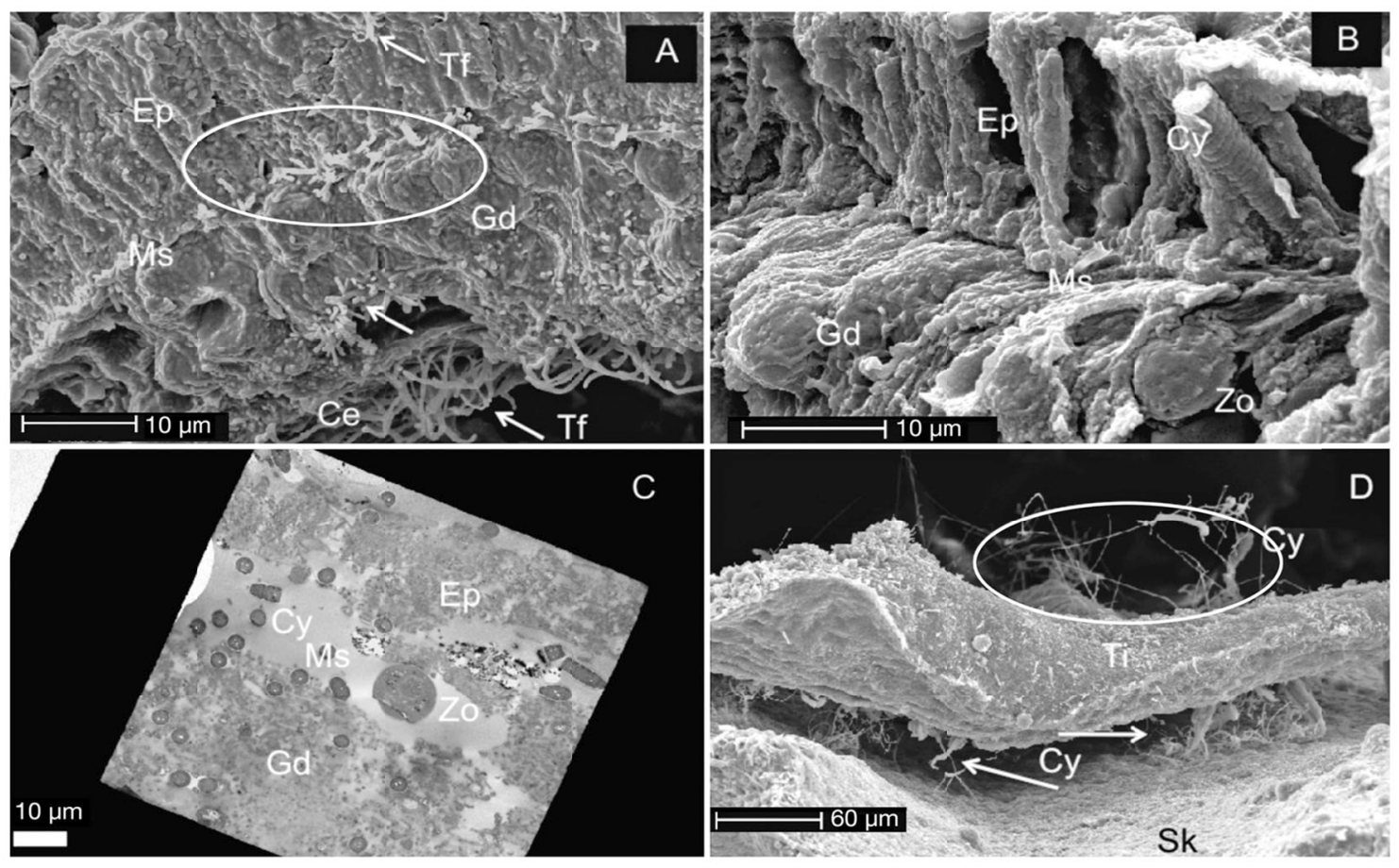
Figure 3.
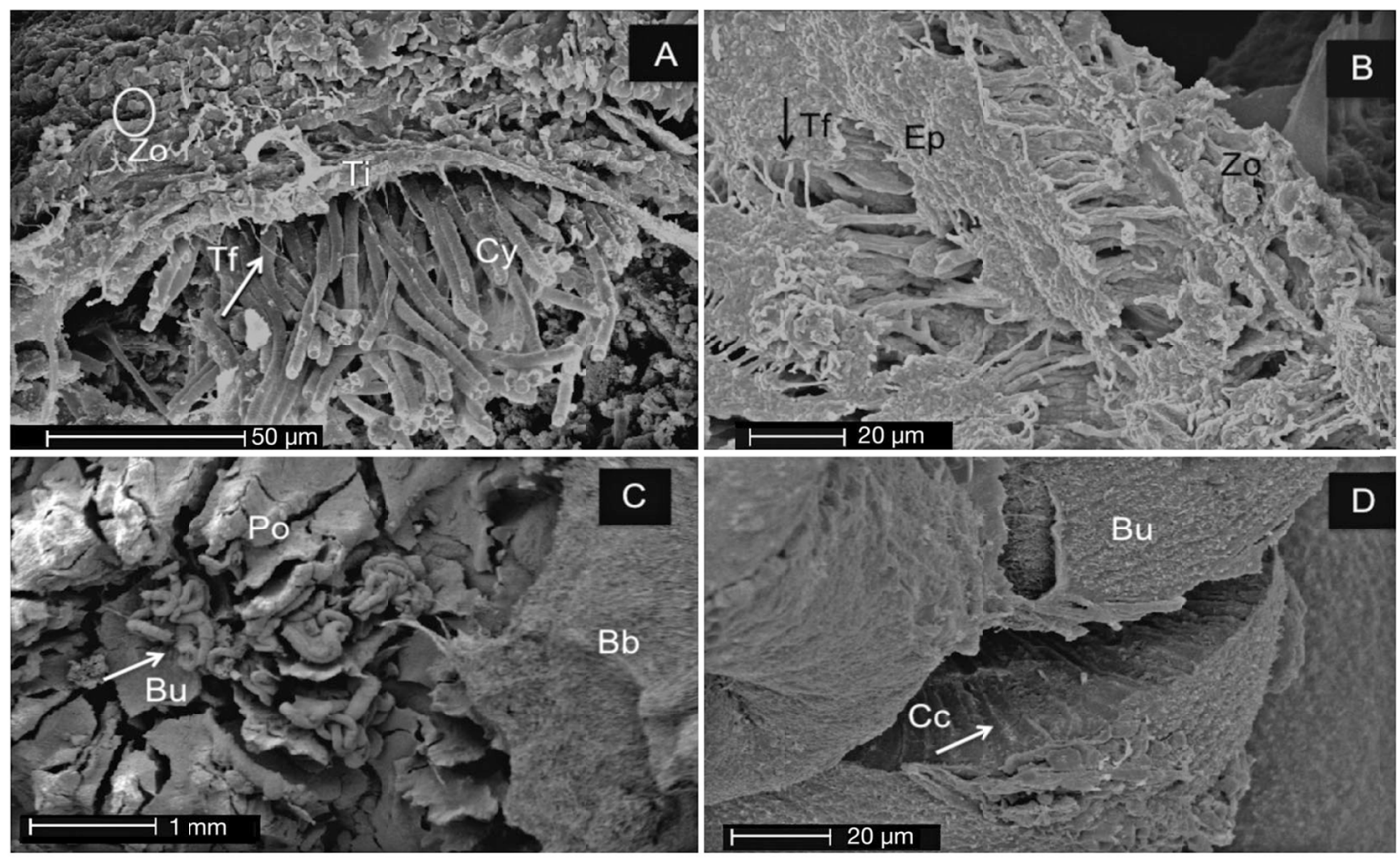
Figure 4.
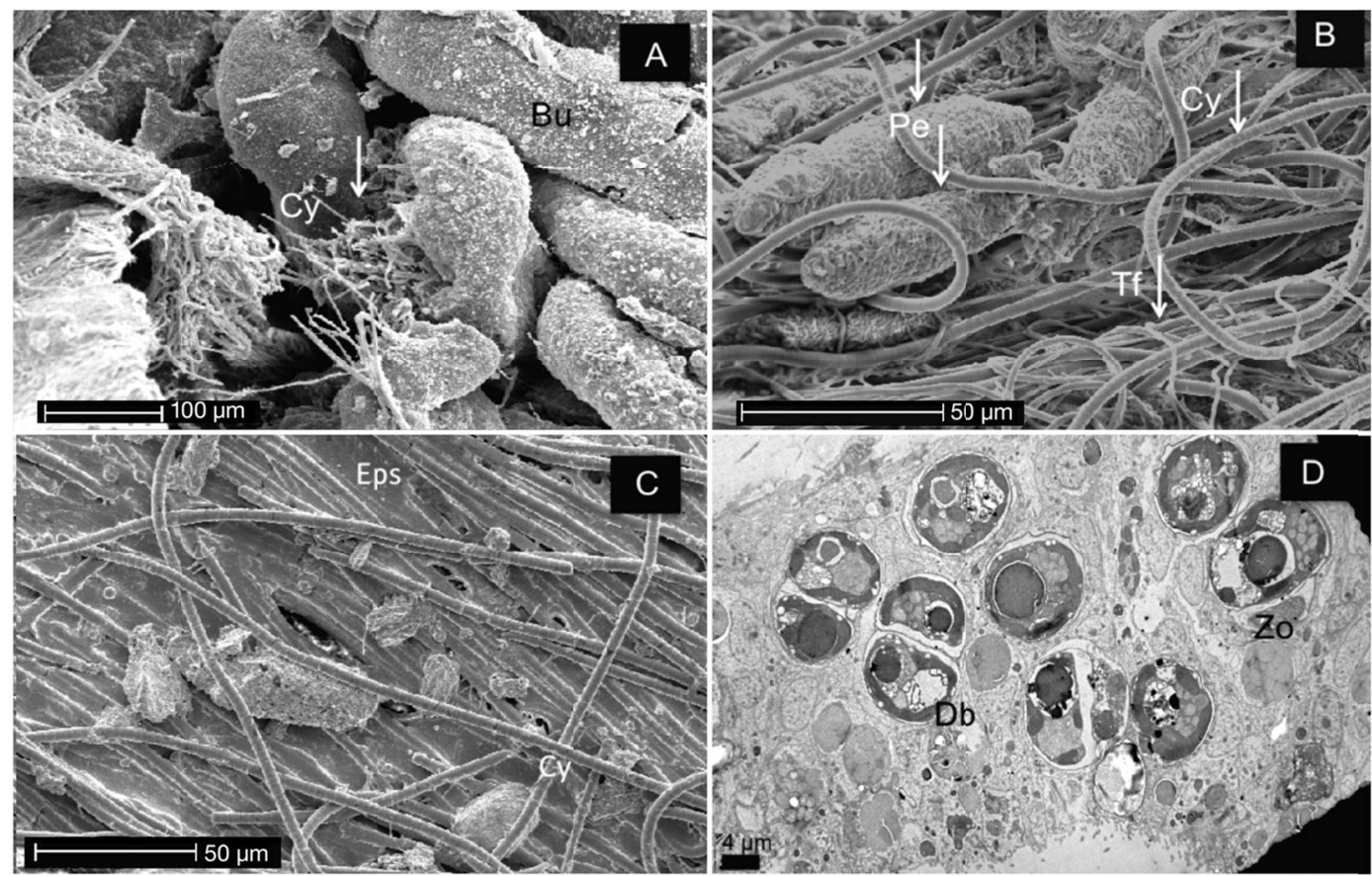
Figure 5.

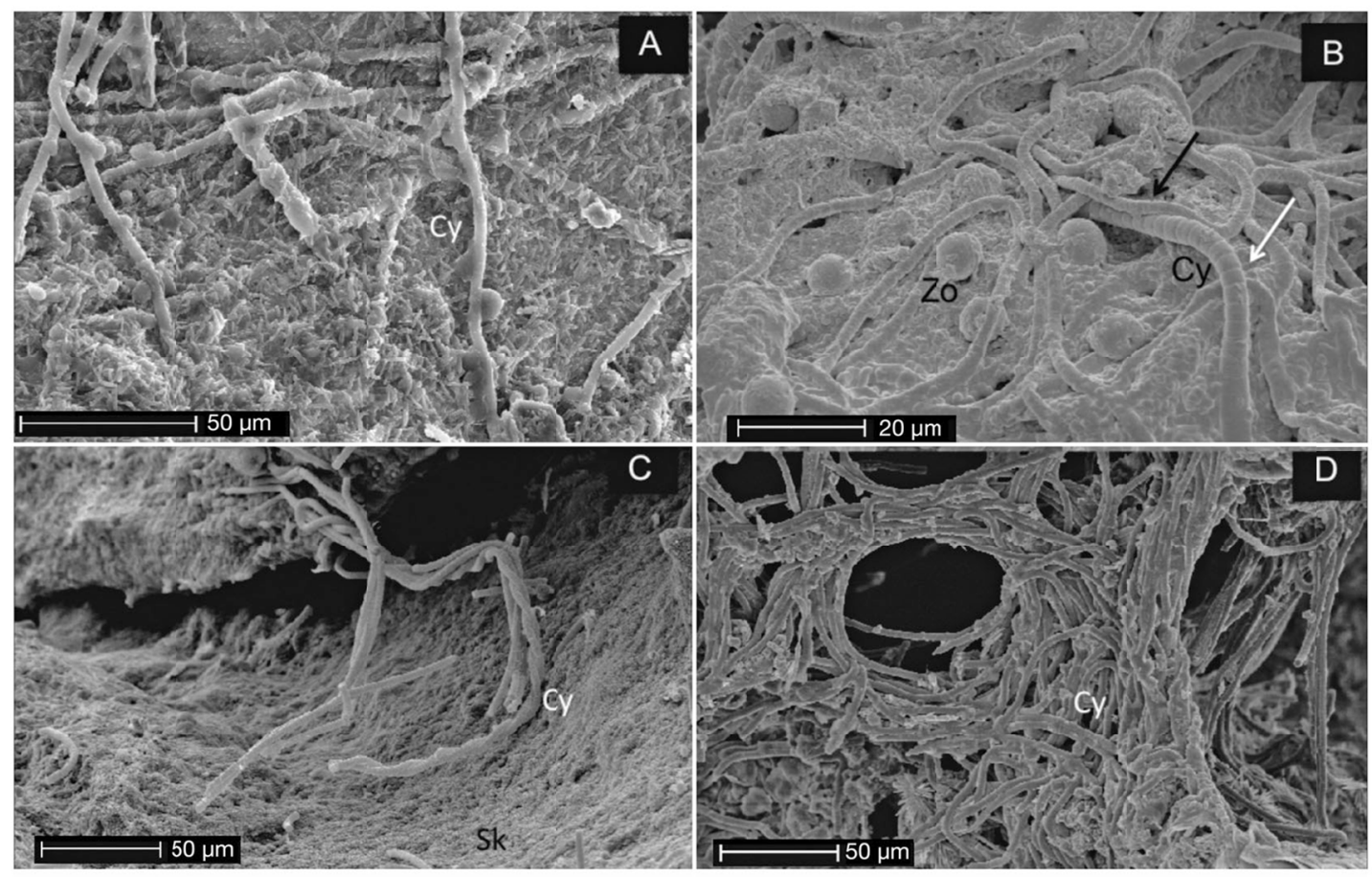


Figure 6.
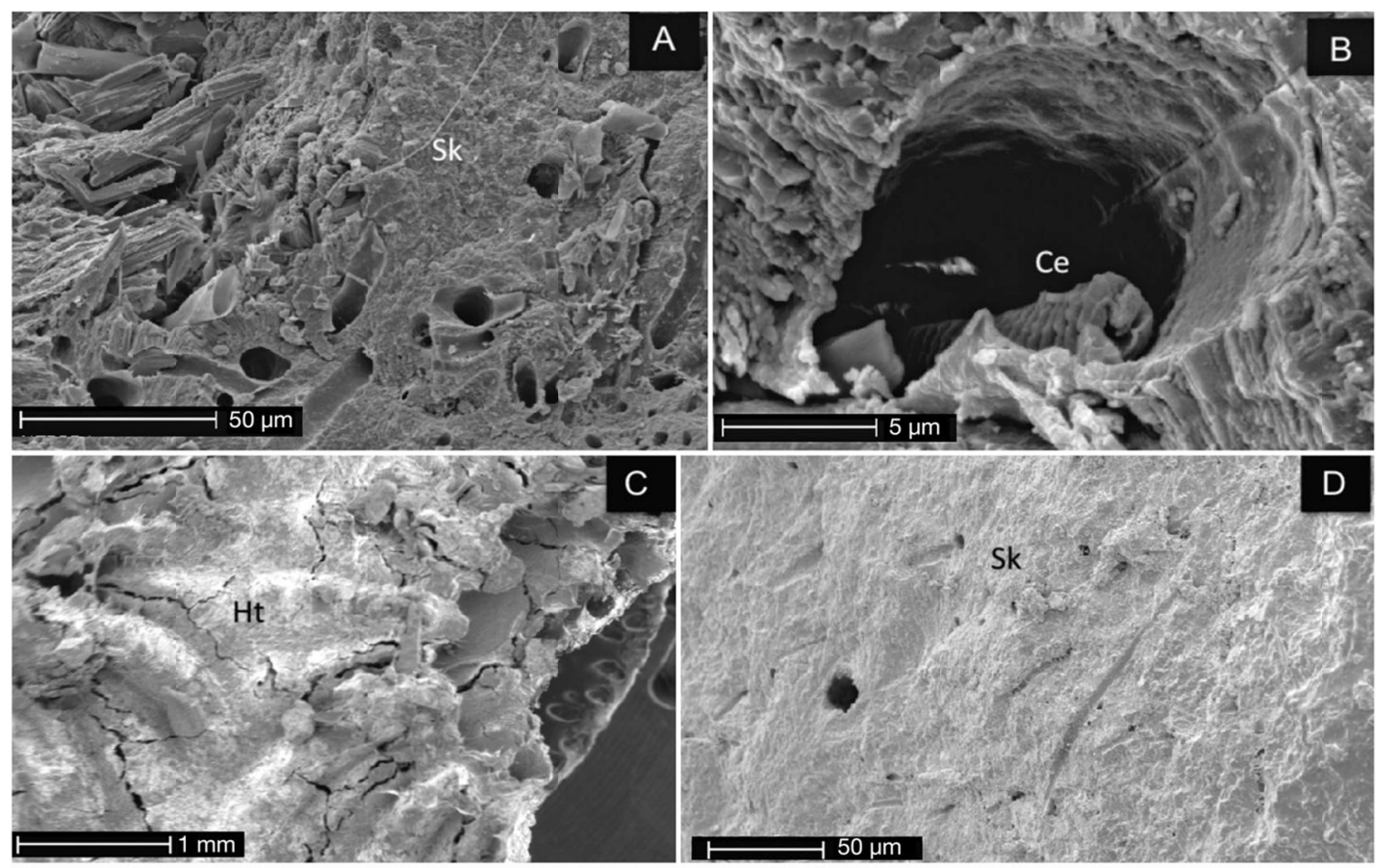


\section{CHAPTER IV}

FINE-STRUCTURE ANALYSIS OF BLACK BAND DISEASE INFECTED CORAL AND CORAL EXPOSED TO BBD TOXINS MICROCYSTIN AND

SULFIDE 


\begin{abstract}
Black band disease (BBD) of corals is a complex pathogenic polymicrobial mat community that lyses coral tissue as it migrates over an infected colony. Two known toxins are produced by BBD microorganisms - sulfide, produced by sulfate-reducing bacteria, and microcystin, produced by cyanobacteria. Experiments were carried out to determine the effects of exposing healthy coral fragments to variable concentrations of purified microcystin, sulfide at a concentration known to exist in BBD, and a combination of the two. Healthy fragments of the coral Montastraea annularis were placed into experimental chambers with known toxin/s for 18 to 22.5 hours. Fine structural analysis using scanning electron microscopy (SEM) showed that toxin exposure resulted in thinning or removal of the coral epidermal layer coupled with degradation of the gastrodermis. These effects were exacerbated when both toxins were used in combination. Exposure to sulfide and the highest concentration of microcystin caused zooxanthellae to dissociate from the coral tissue and to form clusters on the coral surface. Examination of coral fragments infected with BBD was carried out for comparison. It was determined that the effects of exposure to sulfide and microcystin on coral fine structure were consistent, both quantitatively and qualitatively, with the effects of artificially induced and naturally occurring BBD on M. annularis.
\end{abstract}




\section{INTRODUCTION}

Coral diseases are important contributors to the decline of coral reefs worldwide (Rosenberg and Loya, 2004). One coral disease, black band disease (BBD), has a widespread distribution throughout the Caribbean, the Red Sea, the Indo-Pacific, and the Great Barrier Reef (Sutherland et al., 2004), preferentially infecting large, reef-building corals (Richardson 2004). It is one of the more complex and destructive coral diseases known, consisting of a highly variable microbial consortium that exhibits geographic specificity, and to a lesser extent, coral host species specificity (Frias-Lopez et al., 2003; Miller and Richardson, 2011; Voss et al., 2007). The disease is volumetrically dominated by gliding, filamentous, non-heterocystous cyanobacteria from several genera including Oscillatoria, Lyngbya, Geitlerinema, Leptolyngbya, and Phormidium (Cooney et al., 2002; Myers et al., 2007; Sekar et al., 2006), which provide a structural framework for the growth of a diverse microbial community (Rützler and Santavy, 1983).

BBD progresses across an infected coral colony as a contiguous band, from $1 \mathrm{~mm}$ to several centimeters in width, and $1 \mathrm{~mm}$ in thickness, at a rate between $3 \mathrm{~mm}$ and $1 \mathrm{~cm}$ per day, lysing coral tissue as it migrates and leaving behind exposed coral skeleton (Rützler et al., 1983). The rate at which the mat progresses varies depending on environmental factors such as light intensity, elevated temperatures, and nutrients (Boyett et al., 2007; Muller and van Woesik, 2011; Rodriguez and Croquer, 2008; Voss and Richardson, 2006). As a result of 
the complexity of this disease, the mechanisms that lead to the formation of the mat and cause tissue lysis while maintaining band continuity are still in question.

The cyanobacteria present within the BBD mat have been shown with scanning electron microscopy (SEM) to bore through the $\mathrm{CaCO}_{3}$ coral skeleton (Miller et al., 2011) and to penetrate the coral tissue, contributing to tissue lysis (Miller et al., 2011; Rützler et al., 1983). While several mechanisms have been proposed as to how cyanobacteria bore through $\mathrm{CaCO}_{3}$ (Garcia-Pichel, 2006), it is unknown how they penetrate into and through eukaryotic tissue. Prokaryotic penetration into coral tissue has been described previously, resulting in the bleaching (loss of zooxanthellae) of the tissue (Banin et al. 2000), and the penetration of prokaryotes into eukaryotic tissue is an active area of research (Pizarro-Cerdá and Cossart, 2006). It has previously been proposed that physical penetration of BBD cyanobacteria into the coral tissue is aided by chemical degradation that results in a mat containing decaying coral tissue as it migrates across the coral colony (Rützler et al., 1983).

The BBD mat is similar to other stratified, cyanobacteria-dominated microbial mats in extreme environments such as hot spring outflows and hypersaline ponds. In the anoxic zone of marine cyanobacterial mats, including the BBD mat, sulfate-reducing bacteria dominate and produce sulfide through dissimilatory sulfate reduction, resulting in an active sulfur cycle which supports an anoxic, sulfide-rich zone at the base of the mat during the day that often extends into the water column at night (Howarth and Hobbie, 1982; Jørgensen, 
1982; Richardson, 2004). Sulfide is toxic to most eukaryotes, is known to inhibit electron transport in aerobic respiration and to leads to apoptosis and cellular necrosis (Vismann, 1991). The presence of sulfide is required for the initiation of BBD (Richardson et al. 2009). In a mature BBD mat, the anoxic, sulfide-rich zone directly overlies coral tissue (Carlton and Richardson, 1995). Sulfide at the concentrations measured in BBD, coupled with the associated anoxia, has previously been shown to cause coral tissue lysis in the time it takes for the band to migrate over a fixed point on the coral surface (Richardson et al., 1997).

A second toxin that has been found in BBD is the cyanotoxin microcystin (MC). Several variants of microcystin (MC-LA, MC-LF, MC-LY, MC-LR, and MCLW), each of which differs by variable amino acids at two sites, have been identified from both field samples of the BBD mat and from cultures of eleven strains of cyanobacteria isolated from BBD (Gantar et al., 2009; Richardson et al., 2007; Stanić et al., 2010). The most common variant found associated with BBD is MC-LR, which is known to be the most toxic to vertebrates (Carmichael, 1992). The study of the effects of microcystin on invertebrates is limited.

In a previous study (Richardson et al., 2009) it was found, using SEM, that exposure of healthy coral fragments to varying concentrations of purified MC-LR with or without sulfide caused tissue lysis, loss of tissue organization and structure, degradation of the coral epidermis and gastrodermis, and some degradation of the zooxanthellae. In the present study a quantitative analysis of 
these effects was conducted and the analysis was expanded to include comparison with the effects of natural and artificially induced BBD-infections.

\section{MATERIALS AND METHODS}

Sample collection

Table 1 summarizes the number of coral fragments used in this study, the locations from which they were collected, and their use in the infection and exposure experiments. For exposure experiments, apparently healthy fragments, approximately $10 \mathrm{~cm}^{2}$, from colonies of the Montastraea annularis species complex were collected from Florida Keys reefs while SCUBA diving, using a hammer and chisel. Fragments were acclimated in a $150 \mathrm{I}$ laboratory aquarium in artificial seawater (ASW) at $26^{\circ} \mathrm{C}$ under artificial illumination from $10,000 \mathrm{~K}$ metal halide bulbs on a 12:12 light/dark cycle. Light intensity, measured with an underwater light meter (Biospherical Instruments Inc. Model QSI-140) with the diode array positioned at the level of the corals, was $473+/-15$ $\mu \mathrm{mol}$ quanta $\mathrm{m}^{2} \mathrm{~s}^{-1}$. Salinity was maintained at $35 \mathrm{ppt}$.

Fragments with naturally occurring BBD were collected in situ from a coral colony with an active black band infection from Algae Reef in the Florida Keys. The BBD mat was held down with the base of a syringe while the surrounding area was chiseled to remove the fragment from the host coral. Resulting fragments, with intact BBD, were then placed in individual $50 \mathrm{ml}$ Falcon tubes filled with seawater and were fixed for SEM immediately upon return to the boat.

For laboratory BBD infection experiments, coral fragments of the $M$. annularis species complex were collected while SCUBA diving on Horseshoe 
Reef, Lee Stocking Island (LSI) Bahamas and Algae Reef in the Florida Keys, using a hammer and chisel. Apparently healthy fragments collected from LSI were placed into plastic Whirl-Pack bags (Nasco) with seawater and kept at ambient seawater temperature in a cooler until return to shore, where they were placed in aquaria and either artificially infected with BBD (see below) or maintained as healthy controls.

The BBD samples, used for artificial infections, were collected from infected colonies of $M$. annularis from LSI and the Florida Keys using sterile, needleless syringes, and maintained at ambient seawater temperature during transport to the laboratory. The BBD samples were used to infect coral fragments approximately two to three hours after collection.

\section{Exposure experiments}

A total of 39 coral subfragments, each with approximately $1 \mathrm{~cm}^{2}$ of coral surface, was generated from six larger fragments collected on the reef. Subfragments were allowed to recover in the aquarium for at least two weeks prior to exposure to toxin/s.

To assess the effects of exposing corals to MC-LR and sulfide, $1 \mathrm{~cm}^{2}$ (surface area) coral fragments were placed in $150 \mathrm{ml}$ plexiglass chambers constructed so that a stir bar could operate in the chamber without disrupting the coral fragments. Corals were fixed to an elevated stand in the center of the chamber with modeling clay. Chambers were filled with $125 \mathrm{ml}$ of artificial seawater (ASW), and purified MC-LR (obtained from K. Rein, FIU) was added from a $100 \mathrm{mg} \mathrm{I}^{-1}$ stock solution to final concentrations of $1 \mu \mathrm{g} \mathrm{I}^{-1}, 50 \mu \mathrm{g} \mathrm{I}^{-1}$, or 100 
$\mu \mathrm{g}^{-1}$. For exposure to sulfide, chambers with ASW were bubbled with $100 \%$ reagent grade $\mathrm{N}_{2}$ gas under a hood for $20 \mathrm{~min}$, and capped with a rubber stopper. Sulfide from a stock solution of $0.1 \mathrm{M} \mathrm{Na}_{2} \mathrm{~S} \cdot 9 \mathrm{H}_{2} \mathrm{O}$ was added to the anoxic chambers to a final concentration of $0.5 \mathrm{mM}$ with a syringe while carefully lifting the rubber stopper from the chamber under a stream of $\mathrm{N}_{2}$ gas. Chambers without sulfide had cotton placed in the opening to allow exposure to air. For a summary of the treatments used for the exposure experiment and number of fragments exposed to each treatment, refer to Table 1.

After coral fragments were in place and the MC-LR and sulfide compounds were added, the chambers were placed in a $15 \mathrm{I}$ aquarium maintained at $30^{\circ} \mathrm{C}$. Magnetic stirrers were placed underneath each individual chamber to provide water movement (spinning stir bars in chambers). Light was maintained at $246 \pm 9.6 \mu \mathrm{mol}$ quanta $\mathrm{m}^{2} \mathrm{~s}^{-1}$. While the light was lower during the exposure period as compared to the acclimation period, it was not expected to have a significant effect because of the short duration of exposure, and would affect all fragments equally. The exposure period for each fragment ranged from 18 to 22.5 hours before removal from the chambers, at which time fragments were immediately fixed in $2 \%$ gluteraldehyde solution buffered with sodium cacodylate in filtered ASW for electron microscopy.

Black band infection and scanning electron microscopy (SEM)

The fine structure of corals with naturally occurring and artificially induced BBD was investigated and compared with the effects of exposure to MC-LR and sulfide. As noted above, fragments naturally infected with BBD were fixed 
immediately after collection. Healthy fragments were acclimated to aquarium conditions prior to infection. In both cases fragments were prepared for SEM using methods described previously (Miller et al., 2011)

\section{Statistical analysis}

For corals exposed to toxins and infected with $\mathrm{BBD}$, coral tissue integrity was quantified using a rating scale of 1-4. Table 2 indicates the measures used for the rating scale. These measures and the resultant scale were derived from the range of effects observed for coral tissue infected by BBD or exposed to the BBD toxin/s. The average rating for each exposure treatment was compared using one-way ANOVA, with the Tukey Honestly Significant Difference test (Tukey HSD), which provides a conservative estimate of the significant

differences between all treatments (Hayter 1984). The BBD-infected fragments examined using SEM were quantified for comparison, but were not included in the statistical analysis as they were not part of the controlled laboratory experiment.

\section{RESULTS}

The fine structure of coral fragments exposed to MC-LR and/or sulfide was compared with that of BBD-infected fragments and healthy controls by viewing with SEM. Representative images were taken of fragments incubated under each experimental condition (natural and artificially induced BBD infections, and exposure to each concentration or combination of MC-LR/sulfide) as well as experimental controls. In total, 313 images were acquired from seven coral fragments infected with BBD, and 62 images from 39 coral fragments 
exposed to MC-LR and/or sulfide. For each image the coral epidermis and gastrodermis were evaluated for structural integrity, including the placement of zooxanthellae within the gastrodermis.

Quantification of the effects of $M C-L R$, sulfide, and BBD on coral tissue

Figure 1, on the basis of the criteria presented in Table 2, summarizes the quantitative effects of exposure to BBD toxins and BBD infection on coral tissue. Overall, there was a general trend of increasing degradation with an increasing concentration of MC-LR, although at the lowest concentration $\left(1 \mu \mathrm{g} \mathrm{I}^{-1}\right)$ degradation was not significantly different from the control. Exposure to MC-LR at concentrations of 50 and $100 \mu \mathrm{g} \mathrm{I}^{-1}$, with and without sulfide, resulted in significantly greater degradation when compared to the control fragments, as did exposure to sulfide alone. The combination of $100 \mu \mathrm{g} \mathrm{I}^{-1} \mathrm{MC}-\mathrm{LR}$ with sulfide produced a significant synergistic effect when compared to exposure to the lower concentrations of microcystin, without sulfide, and was similar to the BBD infected fragments (Figure 1).

SEM examination of the effects of $M C-L R$, sulfide, and BBD on coral tissue

Control coral fragments, not exposed to any toxins or infected by BBD, exhibited epidermal tissue that was intact, with normal-looking mucocytes, and healthy-looking zooxanthellae in place within the gastrodermis (Figure 2A). Fragments exposed to MC-LR exhibited effects on the coral tissue that varied with the concentration of MC-LR used and whether or not fragments were coexposed to sulfide. Effects ranged from the loss of structure and thinning of the 
epidermis and gastrodermis, to complete tissue lysis with free-floating zooxanthellae. In fragments exposed to $1 \mu \mathrm{g} \mathrm{I}^{-1} \mathrm{MC}-\mathrm{LR}$, the coral tissue exhibited the lowest degree of degradation relative to all other exposure treatments. While the degradation exhibited was greater than in the control fragments, the difference was not significant, and was only significantly lower than fragments exposed to a combination of $100 \mathrm{~g} \mathrm{I}^{-1} \mathrm{MC}$-LR and sulfide (Figure 1). Figure $2 B$ depicts a typical fragment exposed to $1 \mu \mathrm{g} \mathrm{I}^{-1} \mathrm{MC}-\mathrm{LR}$. The tissue exhibited some epidermal thinning, but the gastrodermis remained intact, and zooxanthellae were in place within the gastrodermal tissue. Coral fragments exposed to $50 \mu \mathrm{g} \mathrm{I}^{-1} \mathrm{MC}$-LR varied in condition ranging from pronounced epidermal thinning, with intact gastrodermis in fragments exposed for 18 hours (Figure 2C), to loss of structure of the epidermal tissue with a more degraded gastrodermis in fragments exposed for 22 hours (Figure 2D). These fragments exhibited significantly greater degradation than the control fragments, but significantly less degradation than fragments exposed to $100 \mu \mathrm{gl}^{-1} \mathrm{MC}-\mathrm{LR} / \mathrm{sulfide}$ (Figure 1).

Effects were more severe when coral fragments were exposed to $100 \mu \mathrm{g} \mathrm{I}$ ${ }^{1}$ MC-LR (Figure 3A), although they were not significantly different than the other exposure treatments. These fragments generally exhibited a more pronounced loss of structure and thinning of the epidermis and gastrodermis, with clustering of large groups of zooxanthellae within the degraded tissue areas (Figure $3 \mathrm{~A}$ ). Fragments exposed to sulfide (no MC-LR; Figure 3B) exhibited epidermal tissue 
that was thinned with a loss of structure, while the gastrodermis exhibited marked degradation with loose zooxanthellae placement. The degree of degradation associated with the coral tissue in corals exposed to sulfide was similar to that of the fragments exposed to 50 and $100 \mu \mathrm{g} \mathrm{I}^{-1} \mathrm{MC}$-LR (Figures 2D and 3A).

Exposure to the combination of $100 \mu \mathrm{g} \mathrm{I}^{-1} \mathrm{MC}$-LR and sulfide led to complete lysis of both the epidermis and gastrodermis (Figure 3C, 3D). These effects were significantly greater than the controls and exposure to 1 or $50 \mu \mathrm{g} \mathrm{I}^{-1}$ microcystin, but were not significantly different from exposure to $100 \mu \mathrm{g} \mathrm{I}^{-1}$ of MC$\mathrm{LR}$, sulfide alone, or $50 \mu \mathrm{g} \mathrm{I}^{-1} \mathrm{MC}$-LR plus sulfide (Figure 1). Because of the complete tissue lysis, zooxanthellae were present in clusters on the surface of the coral skeleton. In areas with tissue remaining, little structure was apparent (Figure 3D).

Comparison of coral tissue exposed to toxins with infection by BBD

Coral fragments with natural and artificially induced BBD infections exhibited considerable degradation that varied depending on the location relative to the migrating band. Tissue degradation associated with BBD-infection was consistent with exposure to the combination of microcystin and sulfide and exhibited a level of degradation similar to fragments exposed to $100 \mu \mathrm{g} \mathrm{I}^{-1} \mathrm{MC}-\mathrm{LR}$ in combination with sulfide. In coral tissue ahead of the black band, zooxanthellae were often uncovered as a result of the removal of epidermal tissue (Figure 4A). In areas of coral tissue closer to the leading edge of the BBD mat, the complete removal of the epidermal tissue, loss of structural integrity of 
the gastrodermal tissue, and in many cases the absence of zooxanthellae was associated with cyanobacterial penetration underneath coral tissue layers (Figure 4B). In the trailing end of the band (adjacent to the exposed coral skeleton), all tissue had been effectively lysed, while clusters of zooxanthellae (Figure 4C) and pellets of degraded coral tissue (pervasive throughout the mat, Figure 4D) were present among cyanobacteria on the surface of the exposed coral skeleton. Zooxanthellae in areas of exposed coral skeleton from BBD-infected fragments (Figure 4E) and in fragments exposed to a combination of MC-LR/sulfide (Figure 4F) exhibited some physical deformation, but such cells were typically low in number.

\section{DISCUSSION}

The effects of exposing healthy coral fragments to MC-LR and sulfide were pronounced, and varied both with the concentrations of MC-LR used and whether or not MC-LR was used in combination with sulfide. The observed effects on coral tissue were consistent with the effects associated with BBD infection. Quantitatively, the level of degradation associated with exposing corals to $100 \mu \mathrm{g} \mathrm{I}^{-1}$ MC-LR with sulfide was similar to that of corals infected with BBD. Qualitatively, effects such as tissue thinning and removal, complete tissue lysis, and zooxanthellae expulsion were consistent between corals exposed to the toxins, and those infected with BBD. The results presented here suggest that BBD-associated coral tissue lysis is aided by both the production of cyanotoxins by the cyanobacteria and sulfide by sulfate-reducing bacteria in the BBD 
community, with a significant synergistic effect. Corals exposed to MC-LR and/or sulfide exhibited degradation of the epidermis that included thinning, loss of structure, or complete degradation. Similar observations were apparent in the gastrodermis, which progressively degraded with increasing concentrations of MC-LR that led to the clustering of expelled zooxanthellae, consistent with BBD infection. The combination of $100 \mu \mathrm{g} \mathrm{I}^{-1} \mathrm{MC}$-LR and sulfide had the most severe effect.

It has previously been shown that BBD cyanobacteria penetrate into the coral tissue (Rützler et al., 1983) and more recently that this penetration continues into the coral skeleton (Miller et al., 2011). Rützler et al. (1983) proposed that the penetration of cyanobacteria into BBD-infected coral tissue is aided by chemical lysis. The Rützler et al. (1983) proposal is supported by the present study, which clearly revealed that exposure to two BBD toxins resulted in tissue degradation and lysis. The observed effects of the toxins microcystin and sulfide would then facilitate the penetration of BBD cyanobacteria, or other BBD microorganisms, into the coral tissue.

When coral fragments were exposed to MC-LR and/or sulfide, the resulting removal of the epidermis and degradation of gastrodermis exposed the zooxanthellae to the chemical microenvironment of the immediate surroundings. This tissue removal may have led to the expulsion of zooxanthellae observed to be present on the surface of the coral skeleton, as seen in both toxin-exposed coral fragments and those infected with BBD (Figures 3C, 4C). In the current 
study, the expulsion of zooxanthellae from the coral tissues was the result of the physical degradation of the gastrodermis (within which zooxanthellae are normally enclosed), which had lost structural integrity due to exposure to toxins or BBD infection. The expulsion of the zooxanthellae from the gastrodermis also occurs in other coral diseases such as coral bleaching (Fang et al., 1998; Gates et al., 1995; Lesser, 2011; McCloskey et al., 1996) and yellow band disease (YBD) (Cervino et al., 2004). However, in bleaching and YBD, expulsion was reported to be the result of zooxanthellae degradation and not tissue degradation (Cervino et al., 2004; reviewed in Lesser 2011). While visibly degraded zooxanthellae were apparent in corals exposed to MC-LR and sulfide, as well as those infected with BBD (Figures 4E and 4F), these were typically present in low numbers, and the majority of zooxanthellae showed little morphological deformation.

Black band disease is a complex coral disease consisting of a highly diverse and variable microbial consortium that creates a dynamic and toxic chemical microenvironment. These results show that BBD toxins associated with this environment can cause the complete destruction of eukaryotic tissue as it migrates across the host, and may aid in the penetration of cyanobacteria into the epidermis and gastrodermis of the coral host.

\section{ACKNOWLEDGMENTS}

We thank P. Blackwelder and H. Al-Sayegh at the University of Miami Center for Advanced Microscopy for assistance with the SEM and the Perry Institute for Marine Science for access to the Lee Stocking Island research station in the 
Bahamas. We also thank K. Rein for the purified MC-LR, M. Gantar and L. Kaczmarsky for lab assistance with the exposure experiments, and J. Voss and S. Edge for field (LSI) assistance. Sample collection in the Florida Keys National Marine Sanctuary was conducted under permit number FKNMS-2007-026, and at Lee Stocking Island, Bahamas under permit number CMRC-04- PRJV-01-04C. This is contribution number 207 from the Tropical Biology Program at Florida International University, previously published in the Journal of Invertebrate Pathology. 


\section{REFERENCES}

1. Banin E, Israely T, Kushmaro A, Loya Y, Orr E, Rosenberg E (2000). Penetration of the coral-bleaching bacterium Vibrio shiloi into Oculina patagonica. Appl Environ Microbiol 66: 3031-3036.

2. Boyett HV, Bourne G, Willis BL (2007). Elevated temperature and light enhance progression and spread of black band disease on staghorn corals of the Great Barrier Reef. Mar Biol 151: 1711-1720.

3. Carlton RG, Richardson LL (1995). Oxygen and sulfide dynamics in a horizontally migrating cyanobacterial mat: black band disease of corals. FEMS Microbio Eco 18: 155-162.

4. Carmichael WW (1992). Cyanobacteria secondary metabolites - the cyanotoxins. J Appl Microbio 72(6): 445-459.

5. Cervino JM, Hayes RL, Goreau TJ, Smith GW (2004). Zooxanthellae regulation in yellow blotch/band and other coral diseases contrasted with temperature related bleaching: in situ destruction vs. expulsion. Symbiosis 37: 63-85.

6. Cooney R, Pantos M, Le Tissier M, Rarer A, O'Donnell A, Bythell J (2002). Characterization of the bacterial consortium associated with black band disease in coral using molecular microbiological techniques. Environ Microbio 4: 401-413.

7. Fang LS, Wang JT, Lin KL (1998). The subcellular mechanism of the release of zooxanthellae during coral bleaching. Proc Natl Sci Coun 22: 150-158.

8. Frias-Lopez JA, Bonheyo GT, Jin QS, Fouke BW (2003). Cyanobacteria associated with coral black band disease in Caribbean and Indo-Pacific reefs. Appl Environ Microbio 69: 2409-2413.

9. Gantar M, Sekar R, Richardson LL (2009). Cyanotoxins from black band disease of corals and from other coral reef environments. Microb Ecol 58: 856-864.

10. Garcia-Pichel F (2006). Plausible mechanisms for the boring of carbonates by microbial phototrophs. Sediment Geol 185: 205-213. 
11. Gates RD, Hoegh-Guldberg O, Mcfall-Ngai MJ, Bil KY, Muscatine L (1995). Free amino acids exhibit anthozoans, "host factor" activity: They induce the release of photosynthate from symbiotic dinoflagellates in vitro. PNAS USA 92: 7430-7434.

12. Hayter AJ (1984). A proof of the conjecture that the Tukey-Kramer multiple comparisons procedure is conservative. The Ann of Stat 12(1): 61-75.

13. Howarth RW, Hobbie JE (1982). The regulation of decomposition and heterotrophic microbial activity in salt marsh soils: a review. In: Kennedy VS (Eds.) Estuarine comparisons. Academic Press, New York, pp. 103127.

14. Jørgensen BB (1982). Ecology of the bacteria of the sulfur cycle with special reference to anoxic-oxic interface environments. Phil Trans $\mathrm{R}$ Soc Lond B Biol Sci 298: 548-561.

15. Lesser MP (2011). Coral bleaching: Causes and mechanisms. Earth and Environ Sci 5: 405-419.

16. McCloskey IR, Cove TG, Verde EA (1996). Symbiont expulsion from the sea anemone Anthropleura elegantissima. J Exper Mar Biol Ecol 195: 173-186.

17. Miller AW, Richardson LL (2011). A meta-analysis of 16S rRNA gene clone libraries from the polymicrobial black band disease of corals. FEMS Microbio Eco 75: 231-241.

18. Miller AW, Blackwelder P, Al-Sayegh H, Richardson LL (2011). Finestructural analysis of black band disease-infected coral reveals boring cyanobacteria and novel bacteria. Dis of Aquat Organ 93: 179-190.

19. Muller EM, van Woesik R (2011). Black-band disease dynamics: Prevalence, incidence, and acclimatization to light. Exper Mar Biol Ecol 397: 52-57.

20. Myers JL, Richardson LL, Sekar R (2007). Molecular detection and ecological significance of the cyanobacteria Geitlerinema and Leptolyngbya in black band disease of corals. Appl and Environ Microbio 73: 5173-5182.

21. Pizarro-Cerda J, Cossart P (2006). Subversion of cellular functions by Listeria monocytogenes. J Pathol 208: 215-223. 
22. Richardson L, Kuta K, Schnell S, Carlton R (1997). Ecology of the black band disease microbial consortium. Proc 8th Int Coral Reef Symp 1: 597600.

23. Richardson LL (2004). Black band disease. In: Rosenberg E, Loya Y (Eds.) Coral health and disease. Springer, Berlin, pp. 325-336.

24. Richardson LL, Sekar R, Myers J, Gantar M, Voss J, Kaczmarsky L, Remily E, Boyer G, Zimba P (2007). The presence of the cyanobacterial toxin microcystin in black band disease of corals. FEMS Microbio Eco 272(2): 182-187.

25. Richardson LL, Miller A, Broderick E, Kaczmarsky L, Gantar M, Stanić D, Sekar R (2009). Sulfide, microcystin, and the etiology of black band disease. Dis Aquat Organ 87, 79-90.

26. Rodriguez S, Croquer A (2008). Dynamics of black band disease in a Diploria strigosa population subjected to annual upwelling on the northeastern coast of Venezuela. Coral Reefs 27: 381-388.

27. Rosenberg E, Loya Y (2004). Coral Health and Disease. Springer, Berlin, Germany.

28. Rützler K, Santavy D (1983). The black band disease of Atlantic reef corals. PSZNI Mar Eco 4: 301- 319.

29. Rützler K, Santavy D, Antonius A (1983). The black band disease of Atlantic reef corals III: Distribution, Ecology, and Development. Mar Eco 4(44): 329-358.

30. Sekar R, Mills DK, Remily ER, Voss JD, Richardson LL (2006). Microbial communities in the surface mucopolysaccharide layer and the black band microbial mat of black band diseased Siderastrea siderea. Appl Environ Microbio 72: 5963-5973.

31. Stanić D, Oehrle S, Gantar M, Richardson LL (2011). Microcystin production and ecological physiology of Caribbean black band cyanobacteria. Environ Microbio 13(4): 900-910.

32. Sutherland KP, Porter JW, Torres C (2004). Disease and immunity in Caribbean and Indo-Pacific zooxanthellate corals. Mar Ecol Prog Ser 266: 273-302.

33. Vismann B (1991). Sulfide tolerance: Physiological mechanisms and ecological implications. Ophelia. 34(1): 1-27. 
34. Voss J, Richardson LL (2006). Nutrient enrichment enhances black band disease progression in corals. Coral Reefs 25: 569-576.

35. Voss JD, Mills DK, Myers JL, Remily ER, Richardson LL (2007). Black band disease microbial community variation on corals in three regions of the wider Caribbean. Microb Ecol 54: 730-739. 
Table 1. Location of collection of coral fragments and use in the experiments

\begin{tabular}{|c|c|c|}
\hline Location of coral collection & Toxin/Infection & N of fragments \\
\hline Florida Keys & $\begin{array}{l}\text { Healthy control for } \\
\text { exposure experiments }\end{array}$ & 3 \\
\hline Florida Keys & $1 \mu \mathrm{g} \mathrm{I}^{-1} \mathrm{MC}$ & 6 \\
\hline Florida Keys & $50 \mu \mathrm{g} \mathrm{I}^{-1} \mathrm{MC}$ & 6 \\
\hline Florida Keys & $100 \mu \mathrm{g} \mathrm{I}^{-1} \mathrm{MC}$ & 6 \\
\hline Florida Keys & $0.5 \mathrm{mM}$ sulfide & 6 \\
\hline Florida Keys & $0.5 \mathrm{mM}$ sulfide/ & 6 \\
\hline Florida Keys & $\begin{array}{l}50 \mu \mathrm{g} \mathrm{I}^{-1} \mathrm{MC} \\
0.5 \mathrm{mM} \text { sulfide/ } \\
100 \mu \mathrm{g} \mathrm{I} \mathrm{I}^{-1} \mathrm{MC}\end{array}$ & 6 \\
\hline Bahamas & $\begin{array}{l}\text { Healthy control for } \\
\text { infections experiments }\end{array}$ & 2 \\
\hline Bahamas & Artificial BBD infection & 4 \\
\hline Florida Keys & Natural BBD infection & 2 \\
\hline Florida Keys & Artificial BBD infection & 1 \\
\hline
\end{tabular}


Table 2. Description of the rating scale used to quantify the coral tissue integrity in corals infected with BBD or exposed to microcystin/sulfide. Measures were based on the range of effects seen due to toxin exposure or infection.

\begin{tabular}{cl}
\hline Rating & \multicolumn{1}{c}{ Coral tissue integrity } \\
\hline 1 & $\begin{array}{l}\text { Epidermis and gastrodermis intact with no thinning or degradation } \\
\text { Some epidermal thinning or gastrodermal degradation with loose } \\
\text { zooxanthellae } \\
\text { Epidermis absent or severely degraded and severely degraded } \\
\text { gastrodermis with zooxanthellae missing or in clusters within the } \\
\text { tissue } \\
\text { Coral tissue fully degraded with zooxanthellae in clusters on the } \\
\text { coral skeleton }\end{array}$ \\
\hline
\end{tabular}




\section{FIGURE LEGENDS}

Figure 1. Graph depicting the average tissue degradation rating, based on Table 2 , for corals exposed to varying concentrations of microcystin and sulfide, and those infected with BBD. Means were compared using a one-way ANOVA, with a Tukey HSD post-hoc test. Letters represent significantly similar treatments and error bars represent standard deviation.

Figure 2. SEM images of coral fragments exposed to variable concentrations of MC-LR. Natural cross-sections of the coral tissue layers are shown. A. Control coral fragment. Arrows indicate mucocytes within the epidermis. B. Coral fragment exposed to $1 \mathrm{\mu g} \mathrm{I}^{-1} \mathrm{MC}$-LR for 18 hours exhibiting a thinned epidermis. C. Coral fragment exposed to $50 \mu \mathrm{g} \mathrm{I}^{-1} \mathrm{MC}$-LR for 18 hours exhibiting further thinning of the epidermis. D. Coral fragment exposed to $50 \mu \mathrm{I} \mathrm{I}^{-1}$ for 22 hours exhibiting a loss of structure of the epidermis and zooxanthellae loose within the gastrodermis. ZO: Zooxanthellae, GD: Gastrodermis, EP: Epidermis, Muc: Mucocyte

Figure 3. SEM images of corals exposed to MC-LR and sulfide. Cross-sections of the coral tissue layers are shown. A. Coral fragment exposed to $100 \mu \mathrm{g} \mathrm{I}^{-1} \mathrm{MC}$ LR for 22 hours exhibiting thinned epidermis with a loss of structure, and clustered zooxanthellae within a degraded gastrodermis. B. Coral fragment exposed to $0.5 \mathrm{mM}$ sulfide for 22 hours exhibiting thinned epidermis with 
zooxanthellae loosely held within the gastrodermis. C. Surface of coral fragment exposed to a combination of $0.5 \mathrm{mM}$ sulfide and $100 \mu \mathrm{gl}^{-1} \mathrm{MC}-\mathrm{LR}$ for 18 hours with coral tissue lysed and zooxanthellae clustered on the surface of the coral skeleton. D. Natural section of tissue layers in coral fragment exposed to a combination of $0.5 \mathrm{mM}$ sulfide and $100 \mu \mathrm{g} \mathrm{I}^{-1}$ MC-LR for 22 hours exhibiting severe loss of tissue structure. EP: Epidermis, ZO: Zooxanthellae, GD: Gastrodermis, SK: Coral skeleton, FM: Filamentous microorganism

Figure 4. SEM images of the surface of BBD infected coral fragments at the advancing front of the band (A-B), and the trailing end of the band (C-D). Comparison of degraded zooxanthellae from a BBD infected fragment (E) and an MC-LR/sulfide exposed fragment $(F)$. A. Artificially-induced BBD infection with cyanobacteria migrating underneath the gastrodermis. The epidermis is degraded and zooxanthellae within the gastrodermis are exposed. B. Artificiallyinduced BBD infection with a large accumulation of cyanobacteria migrating underneath degraded gastrodermis. The epidermis is absent. C. Zooxanthellae floating freely among cyanobacteria on the surface of coral skeleton with a natural BBD infection. D. Pellets of degraded epidermal tissue among cyanobacteria on a coral fragment in an artificially-induced BBD infection. E. Coral naturally infected with BBD depicting visibly degraded zooxanthellae on the surface of the coral skeleton. F. Zooxanthellae on exposed coral skeleton of a fragment exposed to $100 \mu \mathrm{g} \mathrm{I}^{-1} \mathrm{MC}$-LR and $0.5 \mathrm{mM}$ sulfide for 18 hours. Note physical deformation in the degraded gastrodermis in plates E and F. EP: 
Epidermis, GD: Gastrodermis, ZO: Zooxanthellae, CY: Cyanobacteria, DZO:

Degraded zooxanthellae, PE: Pellet of epidermal tissue 
Figure 1.

ty

B, C

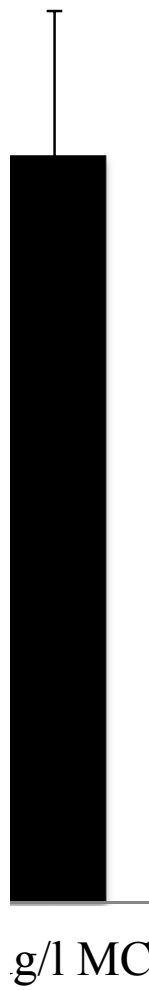

Sulfid 


\section{Figure 2.}

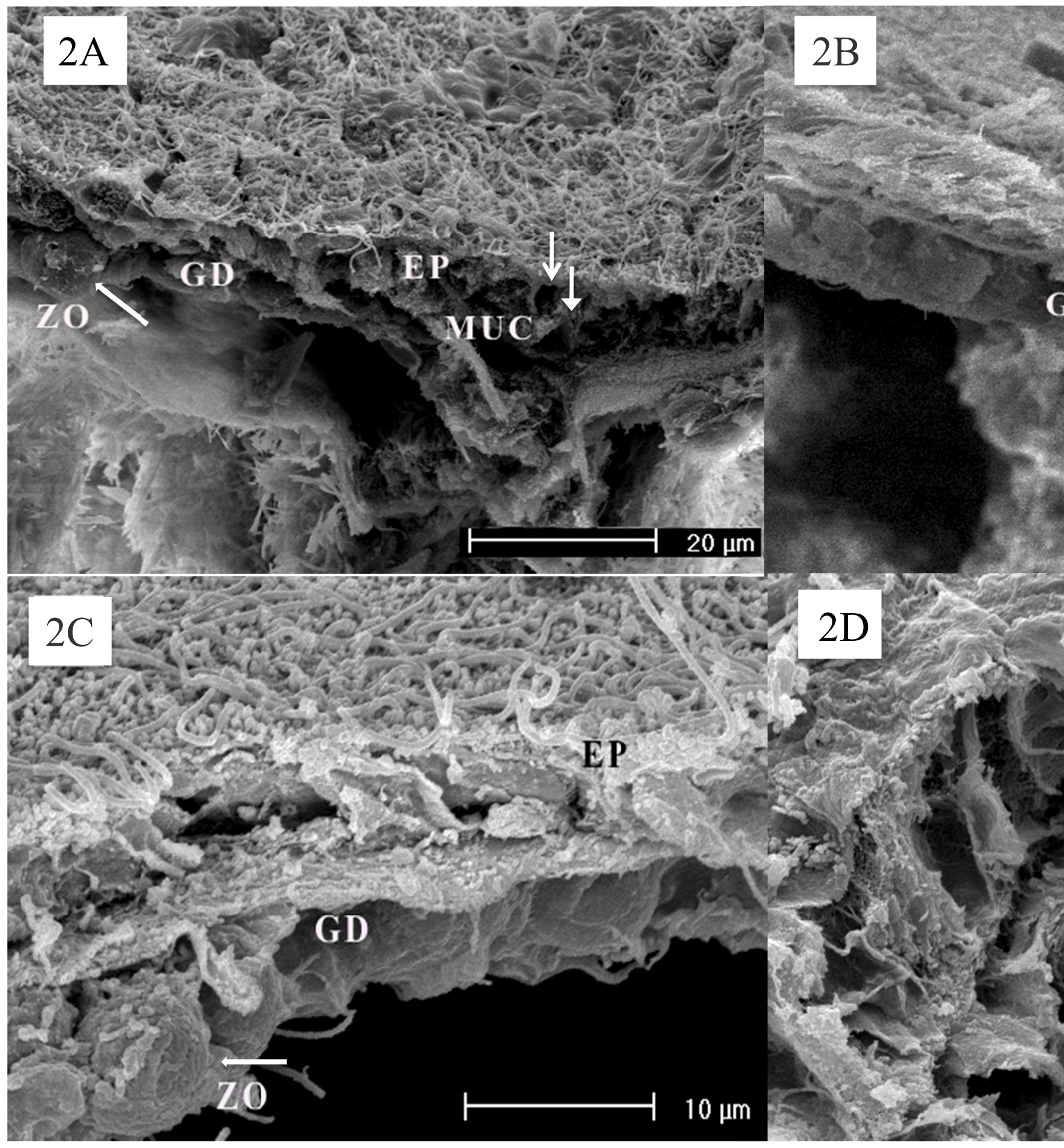




\section{Figure 3.}

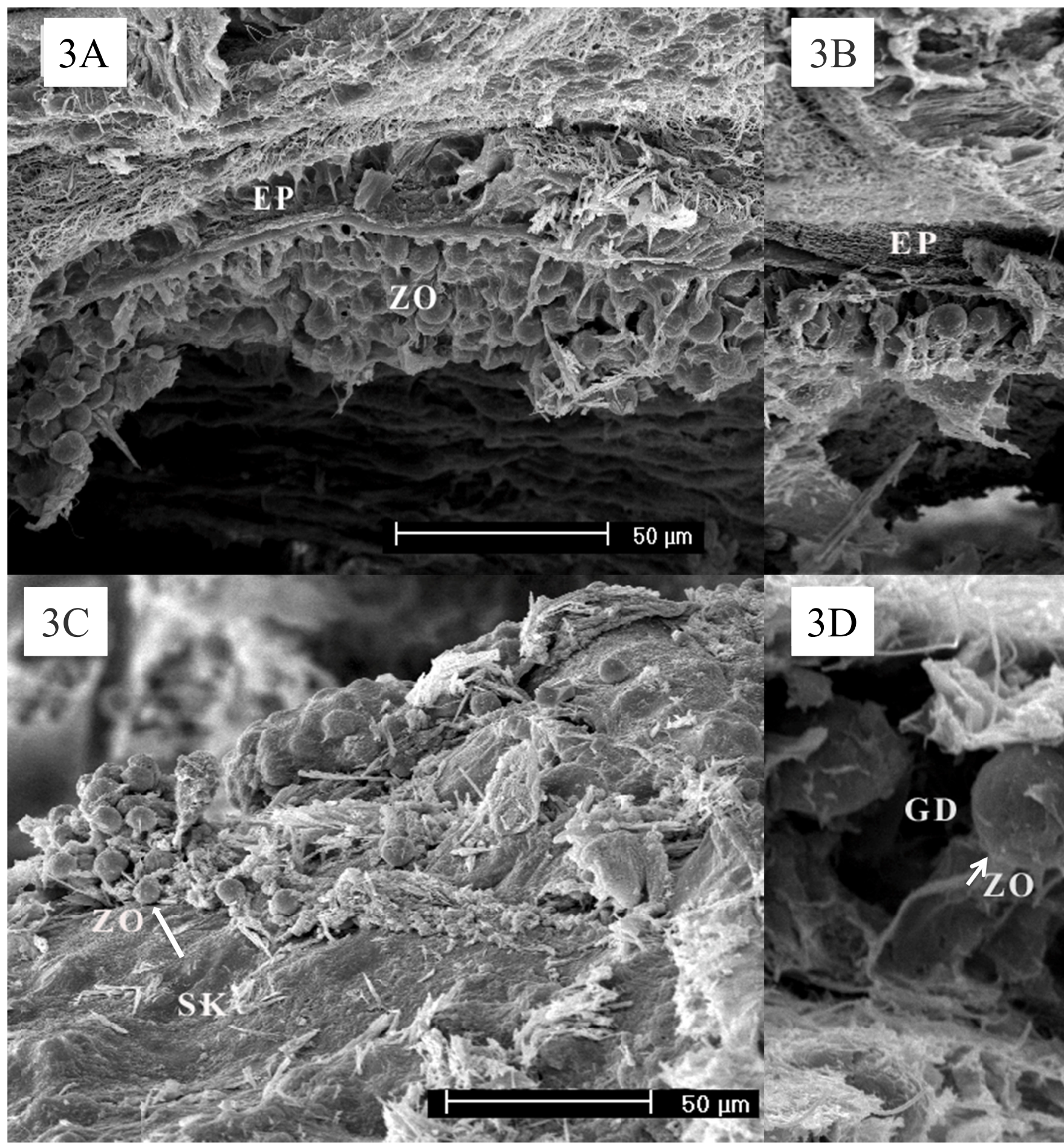


Figure 4.

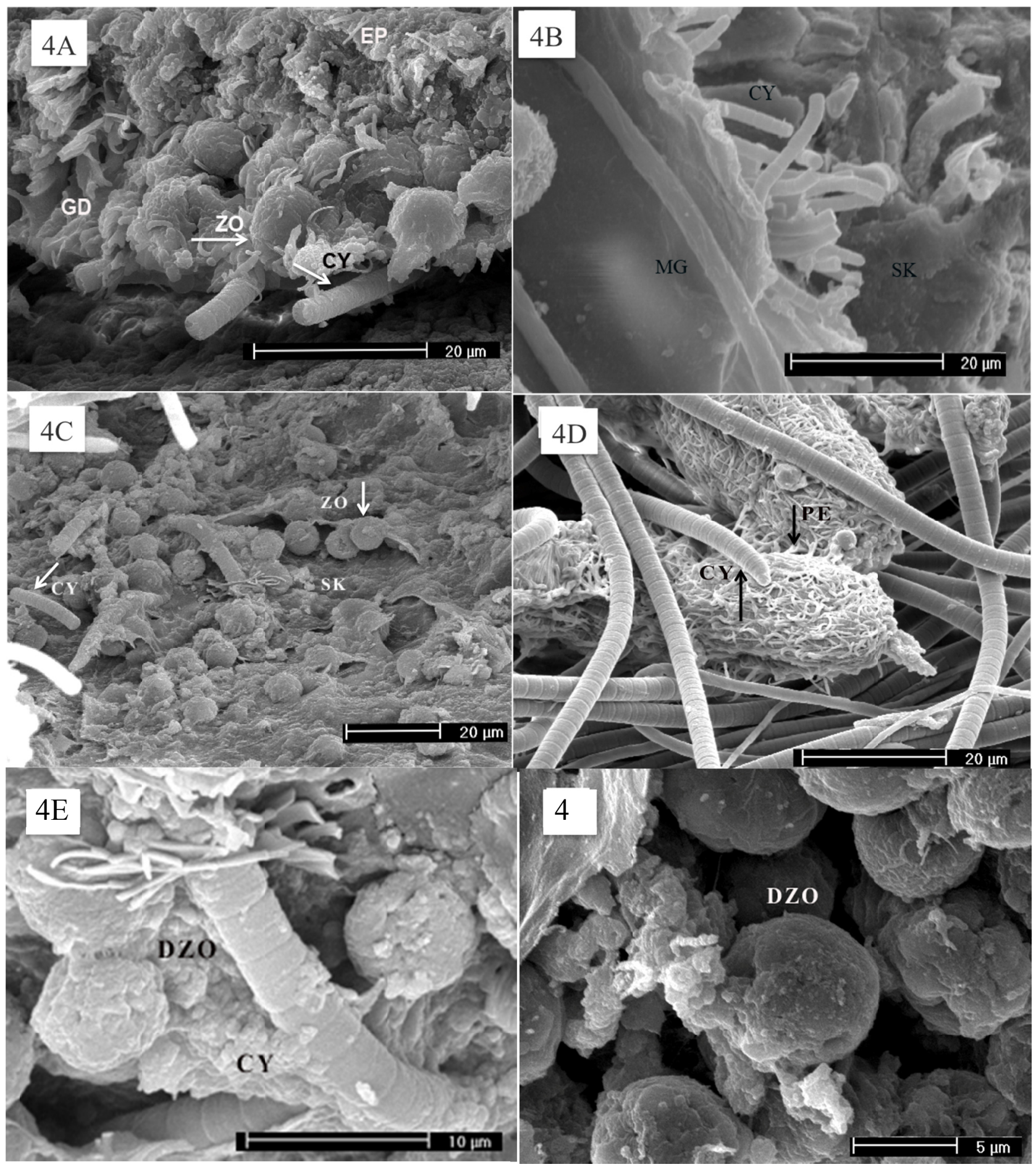




\section{CHAPTER V}

INSIGHTS INTO THE MIGRATION AND DEVELOPMENT OF CORAL BLACK BAND DISEASE REVEALED BY FINE-STRUCTURAL ANALYSIS 


\begin{abstract}
In natural ecosystems and chronic infections, nearly all bacterial growth occurs in biofilms. Bacteria may be present in the planktonic form only ephemerally as a minor proportion of the population. These transient populations of flagellated, planktonic cells are critical to the development of biofilms, which scout out and attach to a suitable substrate, producing extracellular polysaccharides (EPS) which forms a biofilm matrix. While the development of biofilms associated with unicellular bacteria has been well-studied, less is known about how filamentous microorganisms propagate biofilms. Black band disease (BBD) in corals is characterized as a polymicrobial biofilm (mat) community, visually-dominated by filamentous cyanobacteria. The mat is the only known cyanobacterial biofilm that migrates across a living substratum. Detailed analysis using scanning and transmission electron microscopy (SEM and TEM) revealed that individual filaments of BBD cyanobacteria lacking EPS penetrate through coral tissue layers millimeters ahead of the advancing front of the disease, and accumulate, forming clusters of filaments producing EPS. Two types of clusters of cyanobacteria were observed, the first with random orientation and the other with parallel orientation of filaments. The latter exhibited active secretion of EPS while the randomly oriented clusters did not. Within the well-developed band, cyanobacterial filaments were observed to be embedded in EPS and were present as layers of cyanobacteria in parallel orientation. These results suggest that BBD-associated cyanobacteria scout new areas to initiate biofilm formation
\end{abstract}


and orient themselves, producing EPS in a sequential process analogous to other well-studied biofilms, leading to the migration of BBD. 


\section{INTRODUCTION}

Biofilm formation is an important part of microbial differentiation and development (O'Toole et al. 2000, Stoodley et al. 2002). Bacterial growth in biofilms provides protection against harsh and fluctuating environmental conditions, conferring increased resistance to phagocytosis, antibiotics, and immune responses, all important in facilitating bacterial pathogenesis in a wide range of host organisms. Growth in biofilms also provides protection against UV radiation, phage attack, and dehydration in exposed environments (Wolcott and Ehrlich 2008, El-Azizi et al. 2005, Ehrlich et al. 2005). It has been estimated that $65-80 \%$ or more of bacterial infections affecting humans are caused by biofilms (Wolcott and Ehrlich 2008). Because of this, the development of biofilms has been the focus of many studies using different model systems composed of both single and multiple bacterial species (O'Toole et al. 2000, Stoodley et al. 2002).

Black band disease (BBD) exists as a thick biofilm, or thin mat, that migrates across coral colonies completely degrading coral tissues. While the mechanisms that control band migration and development are not known, this horizontal migration of the intact biofilm/mat community across a living coral host is unique (Richardson 1996). The pathogenicity of a polymicrobial mat dominated by filamentous cyanobacteria is also unique and is an important aspect of the disease.

The BBD community always includes sulfate-reducing and sulfideoxidizing bacteria that generate and maintain an active sulfuretum within the band (Carlton and Richardson 1995), a process that may involve interspecific 
quorum sensing (Decho et al. 2010). Biogenesis of sulfide in the BBD community, together with the production of the cyanotoxin microcystin by BBD cyanobacteria, contribute to the destruction and lysis of host coral tissue (Richardson et al. 2007, Richardson et al. 2009, Chapter 3).

Early studies of BBD reported on artificial infection of corals, using freshly collected black band material from infected corals. Small clusters of cyanobacteria separated from the consortium after being placed on a coral fragment and penetrated into the coral tissue, leading to the eventual development of the BBD biofilm on the coral host (Rützler et al. 1983). Scanning and transmission electron microscopy (SEM and TEM) were used here to investigate the horizontal progression of BBD across an infected coral host. It is proposed that BBD progression is a continuation of the initial infection process. Therefore, similar to other biofilm systems, scout cyanobacteria separate from the mature biofilm to migrate ahead, penetrate through intact coral tissue in front of the band and accumulate, initiating the development of a new biofilm, directly adjacent to the mature biofilm.

\section{MATERIALS AND METHODS}

Sample collection and preparation for microscopy are described in detail in Chapter 3. Briefly, seven BBD-infected fragments of the coral Montastraea annularis species complex were used for the present study. Five fragments, from aquarium maintained colonies or from apparently healthy colonies on Horseshoe Reef at Lee Stocking Island, Bahamas, were artificially infected with freshly collected BBD. The resultant band was allowed to migrate for a period of 
2-3 days after which the fragment was immersed in a fixture composed of $2 \%$ glutaraldehyde in sodium cacodylate buffered seawater. The remaining two fragments, collected from a naturally BBD-infected coral colony at Algae Reef in Key Largo, Florida, were fixed immediately after collection. In the laboratory after a buffer wash all fragments were post-fixed in $1 \%$ osmium tetroxide, rinsed with buffer, dehydrated in a graded series of ethanols, and processed for SEM (critical point dried) and/or TEM (embedded in Spurr@ resin) analysis (see chapter three).

\section{RESULTS}

In the present study a total of 407 SEM and TEM images from seven naturally and artificially BBD-infected fragments of the coral host Montastraea annularis (species complex) were examined, focusing on the interactions of the biofilm with the coral tissue at the leading edge of the band. Examination of the BBD biofilm/mat on infected fragments using SEM revealed that, despite the homogenous appearance of the disease band macroscopically, the mat exhibited spatial heterogeneity. In both artificially and naturally infected coral fragments, individual cyanobacterial filaments were observable up to two millimeters ahead of the advancing front of the BBD biofilm, and could be seen penetrating through the mesoglea, the coral tissue layer between the epidermis and gastrodermis (Figure 1).

Groups of filaments were present as loose aggregations that formed clusters between and underneath coral tissue layers, and could be seen separating the coral tissue from the skeleton. Some of the clusters (Figure 2) 
consisted of cyanobacteria that appeared to be randomly oriented relative to each other, and had no associated extracellular polysaccharides (EPS). Other clusters exhibited active EPS secretion associated with individual filaments that were oriented in parallel (Figure 3). In some cases such filaments appeared to be enveloped in EPS, but there was no distinct layer of EPS matrix holding the filaments together.

The differentiation between EPS and non-EPS producing BBD cyanobacteria can be clearly seen in TEM micrographs (Figures 4 and 5). Some clusters of cyanobacteria embedded in coral tissue had a well-defined ring of EPS surrounding each cyanobacterial filament (shown in cross-section in Figure 4), while other cyanobacteria, also present in clusters and embedded in tissue, had no apparent ring (Figure 5).

Examination of BBD in the center of the mat (between the leading edge and the exposed coral skeleton behind the band) revealed a much more organized band structure (Figure 6). Thick layers of cyanobacteria were observed to be oriented in parallel and were in much closer physical association than those in the coral tissue in front of the band (Figure 7). It was also observed that parallel filaments were embedded in a distinct EPS matrix (Figure 8).

\section{DISCUSSION}

The observations of the behavior of individual filamentous BBD cyanobacteria suggest that BBD biofilm migration is analogous to the scouting behavior of unicellular bacteria in other biofilms. Specifically, it appears that the BBD biofilm advances across the host coral substrate by a mechanism in which 
scout cyanobacteria separate from the mature biofilm, both leaving the EPS matrix and discontinuing the secretion of EPS. The scouts then penetrate into adjacent intact coral tissue through the mesoglea, where they accumulate into clusters, secrete EPS and embed the surrounding cyanobacteria and other associated BBD bacteria in a new EPS matrix.

Clusters of cyanobacteria were present millimeters ahead of the distinct, pathogenic disease band. These clusters could be seen penetrating through, and underneath, coral tissue. Previous studies have shown that the cyanobacteria from BBD are able to penetrate into coral tissue (Rützler et al. 1983, Barneah et al. 2007, Sato et al. 2009, Chapter 3), and into coral skeleton (Chapter 3). In a parallel manner, unicellular scouts, released from a mature biofilm, invade and colonize a new surface via flagella-powered motility, followed by EPS secretion and coaggregation to form a biofilm matrix once attached (O'Toole et al. 2000, Stoodley et al. 2002, Rickard et al. 2003). In the case of $\mathrm{BBD}$, the matrix is a newly formed biofilm directly adjacent to the previous one, resulting in the horizontal 'migration' of the BBD lesion.

The BBD cyanobacteria ahead of the mature band in the current study were aggregated in clusters that exhibited either random (Figure 2), or parallel (Figure 3), orientation. In these areas of the infected coral, the BBD cyanobacteria either exhibited no EPS secretion (Figures 2 and 4), or were associated with EPS on the surface of filaments (Figures 3 and 5). Some of these clusters were embedded in EPS (Figure 8). 
There appeared to be a transition between the clusters of cyanobacteria in the tissue in front of the band, and the fully formed band itself. Specifically, randomly oriented, non-EPS forming clusters may transition into parallel-oriented filaments that begin to produce EPS, which also appear to transition into more closely packed, layered clusters. In some of the transitional clusters where cyanobacteria exhibited parallel orientation there was significant layering, leading to aggregations that were several filaments thick (Figure 7). These aggregations can be considered to be biofilms, that further coaggregate to form the mature mat.

Previous studies have suggested that BBD cyanobacteria, which are the dominant component of the BBD community, provide the structural framework of the BBD mat (Rützler \& Santavy 1983). This hypothesis is supported by the results presented in the current study. Furthermore, the observed layering of filaments, and differentiation in EPS production, are consistent with the results of other studies focused on formation of biofilms. In well-studied, model biofilm systems, composed of unicellular bacteria, the development of the biofilm occurs after free-living, planktonic bacteria attach to a surface and begin to secrete EPS. This EPS then embeds and surrounds the biofilm-forming bacteria in an adhesive matrix (Gacesa 1998, Kolenbrander et al. 1999, Flemming et al. 2000, O'Toole et al. 2000, Handley et al. 2001, Rickard et al. 2003). Mutations in the genes controlling EPS secretion lead to altered attachment behavior and biofilm formation, further strengthening this relationship between EPS and biofilm formation (Makin \& Beveridge 1996, Genevaux et al. 1999). 
As BBD cyanobacteria migrate into tissue ahead of the band, they appear to stop producing EPS. The clusters of filaments behind these leading BBD cyanobacteria produce small amounts of EPS that accumulate and bind the filamentous matrix into new biofilm that thickens to become a mat. This secretion of EPS compound embeds not only the surrounding cyanobacteria but also the many other BBD-associated bacteria into a distinct layer that constitutes the mature biofilm/mat.

The proposed model of biofilm proliferation shares several characteristics both with other cyanobacterial dispersive mechanisms, and with other models of biofilm development. For example, when the roots of wheat plants are inoculated (Gantar et al. 1991) with a culture of cyanobacteria from the filamentous, nitrogen-fixing genus Nostoc, colonization proceeds by the production of hormogonia, short filaments of only a few cells which exhibit gliding motility, and are differentiated from vegetative cells. These hormogonia, which, unlike vegetative filaments, do not possess a mucilaginous (EPS) sheath, initially colonize the root nodule to form a symbiosis with the recipient plant. As the hormogonia develop and elongate by cell division they begin to secrete mucilage. At the same time, a subset of vegetative cells along the filament differentiate into heterocysts, the site of nitrogen fixation. The filaments lose their motility, developing into aseriate packages of cells, and can release more hormogonia for further colonization of new host roots. They are also able to directly penetrate the root epidermis and cortex (Gantar et al. 1991), similar to the cyanobacterial penetration through the coral tissue layers in BBD. While hormogonia have not 
been observed in BBD, these similarities suggest a common cyanobacterial dispersal mechanism based on the observation that BBD scout cyanobacteria lack any apparent EPS on their surfaces (Figures 1,2).

The detachment of bacteria from mature biofilms and reversion to the motile, planktonic form is one of the mechanisms used for the formation of new biofilms by unicellular, flagellated bacteria in different model biofilm systems such as those associated with P. aeruginosa (Korber et al. 1994, O'Toole and Kolter 1998), P. fluorescens (de Weger et al. 1987 and Prigent-Combaret et al. 1999), and E. coli (Watnick et al. 1999). Biofilm forming strains of these species use flagella to find and attach to a surface, converting to twitching motility before becoming irreversibly attached. Mutant strains of $P$. aeruginosa that are defective in flagellar synthesis are unable to form biofilms (O'Toole and Kolter 1998). However, while flagellated motility greatly facilitates biofilm formation in V. cholerae, mutants lacking flagellar synthesis can form a biofilm in the rare case that they become attached to a surface (Watnick et al. 1999, and Watnick and Kolter 1999).

The results presented here show that the general model of biofilm formation employed by unicellular bacteria, in which motile bacteria serve as primary colonizers, or "scouts", that gradually accumulate on a surface, coaggregate, and secrete EPS to embed surrounding cells in an adhesive matrix, is directly analogous to the migration of the pathogenic, polymicrobial, filamentous cyanobacteria-dominated biofilm that is black band disease. Despite these similarities there are distinct differences between the BBD system and 
other model biofilm systems. In BBD biofilm formation, the filamentous cyanobacteria use gliding as the motility mechanism. While many other biofilms are known to be pathogenic, the BBD biofilm is unique in that it continually migrates across the host surface, whereas other pathogenic biofilms appear to irreversibly attach to their substrate. Finally, although the BBD biofilm consortium is dependent on a living coral host to support the biofilm community, the primary constituents of BBD biofilms are photosynthetic bacteria which are capable of growth by photoautotrophy and are not dependent on the use of the coral host as a resource to support growth.

\section{ACKNOWLEDGMENTS}

We thank Drs. Josh Voss and Sarah Edge for their help in providing samples for this analysis as well as the Perry Institute for Marine Science who provided the research station in the Bahamas. Sample collection in the Florida Keys National Marine Sanctuary was conducted under permit number FKNMS-2007-026, and at Lee Stocking Island, Bahamas under permit number CMRC-04- PRJV-01-04C. 


\section{REFERENCES}

1. Barneah O, Ben-Dov E, Kramarsky-Winter E, Kushmaro A (2007). Characterization of black band disease in Red Sea stony corals. Environ Microbiol 9: 1995-2006.

2. Carlton RG, Richardson LL (1995). Oxygen and sulfide dynamics in a horizontally migrating cyanobacterial mat: black band disease of corals. FEMS Microbiol Ecol 18: 155-162.

3. Decho AW, Norman RS, Visscher PT (2010). Quorum sensing in natural environments: emerging views from microbial mats. Trends in Microbio 18(2): 73-80.

4. de Weger LA, van der Vlught CIM, Wijfes AHM, Bakker PAHM, Schippers B, Lugtenberg B (1987). Flagella of a plant-growth-stimulating Pseudomonas fluorscens are required for colonization of potato roots. J Bacteriol 169: 27692773.

5. Edmunds PJ (1991). Extent and effect of black band disease on a Caribbean reef. Coral Reefs 10(3): 161-165.

6. Ehrlich GD, Hu FZ, Shen K, Stoodley P, Post JC (2005). Bacterial plurality as a general mechanism driving persistence in chronic infections. Clin Orthop Relat Res 437: 20-24.

7. El-Azizi M, Rao S, Kanchanapoom T, Khardori N (2005). In vitro activity of vancomycin, quinupristin/dalfopristin, and linezolid against intact and disrupted biofilms of staphylococci. Ann Clin Microbiol Antimicrob 4(2): 1-9.

8. Flemming HC, Wingender J, Mayer C, Korstgens V, Borchard W (2000). Cohesiveness in biofilm matrix polymers. Community Structure and Cooperation in Biofilms. SGM Symposium series 59, Cambridge, UK.

9. Gacesa, P (1998). Bacterial alginate biosynthesis: recent progress and future prospects. Microbiol 144: 1133-1143.

10. Gantar M, Kerby NW, Rowell P (1991). Colonization of wheat by nitrogenfixing cyanobacteria III: The role of a hormogonia-promoting factor. New Phyto 124(3): 505-513.

11. Genevaux P, Bauda P, DuBow MS, Oudega B (1999). Identification of the Tn10 insertions in the rfaG, rfaP, and galU genes involved in lipopolysaccharide core biosynthesis that affect Escherichia coli adhesion. Arch Microbiol 172: 1-8. 
12. Handley PS, Rickard AH, High NJ, Leach SA (2001).

Coaggregation- is it a universal biofilm phenomenon? Biofilm Community Interactions: Chances or Necessity? Bioline Press, Cardiff, UK.

13. Kolenbrander PE, Anderson RN, Clemens DL, Whittaker CJ, Klier CM (1999). Potential role of functionally similar coaggregation mediators in bacterial succession. Dental Plaque Revisited. Bioline Press, Cardiff, UK.

14. Korber DR, Lawrence JR, Caldwell DE (1994). Effect of motility on surface colonization and reproductive success of Pseudomonas fluorescens in dualdilution continuous culture and batch culture systems. Appl Environ Microbiol 60: 1421-1429.

15. Kuta KG, Richardson LL (1996). Abundance and distribution of black band disease on coral reefs in the northern Florida Keys. Coral Reefs 15: 219-223.

16. Makin SA, Beveridge TJ (1996). The influence of A-band and B-band lipopolysaccharide on the surface characteristics and adhesion of Pseudomonas aeruginosa to surfaces. Microbiol 142: 299-307.

17. Miller AW, Blackwelder P, Al-Sayegh H, Richardson LL (2011). Finestructural analysis of black band disease-infected coral reveals boring cyanobacteria and novel bacteria. Dis of Aquat Organ 93: 179-190.

18. Miller AW, Richardson LL (2011a). A meta-analysis of 16S rRNA gene clone libraries from the polymicrobial black band disease of corals. FEMS Microbio Ecol 75, 231-241.

19. Miller AW, Richardson LL (2011b). Fine-structural analysis of BBD infected coral and coral exposed to the BBD toxins microcystin and sulfide. J Invert Path.

20. Prigent-Combaret C, Vidal O, Dorel C, Lejeune P (1999). Abiotic surface sensing and biofilm-dependent regulation of gene expression in Eschericia coli. J Bacteriol 181(19): 5993-6002.

21. O'Toole GA, Kolter R (1998). The initiation of biofilm formation in Pseudomonas aeruginosa WCS365 proceeds via multiple, convergent signaling pathways: a genetic analysis. Mol Microbiol 28: 449-461.

22. O'Toole GA, Kaplan HB, Kolter R (2000). Biofilm formation as microbial development. Ann Rev Microbiol 54: 49-79. 
23. Richardson LL (1996). Horizontal and vertical migration patterns of Phormidium corallyticum and Beggiatoa spp. associated with black band disease of corals. Microb Ecol 32: 323-335.

24. Richardson LL, Sekar R, Myers JL, Gantar M, Remily ER, Kaczmarsky LT, Voss JD, Boyer GL, Zimba PV (2007). The presence of the cyanobacterial toxin microcystin in black band disease of corals. FEMS Microbio Eco 272:182-187.

25. Richardson LL, Miller AW, Broderick E, Kaczmarsky LT, Gantar M, Stanić D, Sekar R (2009). Sulfide, microcystin, and the etiology of black band disease. Dis of Aquat Org 87:79-90.

26. Rickard AH, Gilbert P, High NJ, Kolenbrander PE, Handley PS (2003). Bacterial coaggregation: an integral process in the development of multi-species biofilms. Trends in Microbiol 11(2): 94-100.

27. Rützler K, Santavy D (1983). The black band disease of Atlantic coral reefs. PSZN I: Mar Ecol 4: 301-319.

28. Rützler K, Santavy D, Antonius A (1983). The black band disease of Atlantic coral reefs III: distribution, ecology, and development. PSZN I: Mar Eco 4: 329-358.

29. Sato Y, Willis BL, Bourne DG (2009). Successional changes in bacterial communities during the development of black band disease on the reef coral, Montipora hispida. ISME J 1-12.

30. Stoodley P, Sauer K, Davies DG, Costerton JW (2002). Biofilms as complex differentiated communities. Ann. Rev. Microbiol. 56, 187-209.

31. Sutherland KP, Porter JW, Torres C (2004). Disease and immunity in Caribbean and Indo-Pacific zooxanthellate corals. Mar Ecol Prog Ser 266: 273-302.

32. Voss JD, Richardson LL (2006). Nutrient enrichment enhances black band disease progression in corals. Coral Reefs 25: 569-576.

33. Voss JD, Mills DK, Meyers JL, Remily ER, Richardson LL (2007). Black band disease microbial community variation on corals in three regions of the wider Caribbean. Microb Ecol 54: 730-739.

34. Watnick PI, Kolter R (1999). Steps in the development of a Vibrio cholerae El Tor biofilm. Mol Microbiol 34(3): 586-595. 
35. Watnick PI, Fullner KJ, Kolter R (1999). A role for the mannosesensitive hemaglutinin in biofilm formation by Vibrio cholerae El Tor. $\mathrm{J}$ Bacteriol 181: 3606-3609.

36. Wolcott RD, Ehrlich GD (2008). Biofilms and chronic infections. JAMA 299(22): 2682-2684. 


\section{FIGURE LEGENDS}

Figure 1. SEM of a scout cyanobacterium in coral black band disease (BBD). An individual filament of a BBD cyanobacterium penetrating through the mesoglea of the coral tissue, between the epidermis and gastrodermis, approximately $2 \mathrm{~mm}$ ahead of the advancing front of the disease biofilm (band). No EPS is present. CY: cyanobacteria, GS: gastrodermis, EP: epidermis, Mg: mesoglea.

Figure 2. SEM images of coral tissue in front of the leading edge of the BBD mat showing cluster of cyanobacteria exhibiting random orientation, and no apparent EPS, underneath the coral tissue. CY: cyanobacteria, TI: coral tissue.

Figure 3. Close up of EPS secretion associated with individual cyanobacterial filaments within a cluster with parallel orientation. White arrow indicates ringed EPS structure around terminal cell; and the black arrow indicates a disk of EPS covering the terminal cell. CY: cyanobacteria, TI: coral tissue

Figure 4. TEM image of a cross-section of cyanobacteria with no EPS secretion from cyanobacteria at the interface with coral tissue and the disease band. CY: cyanobacteria, TI: coral tissue. 
Figure 5. TEM image of a cross-section of cyanobacteria within coral tissue exhibiting a ring of EPS surrounding the filament. CY: cyanobacteria, TI: coral tissue, EPS: exopolysaccharides.

Figure 6. Parallel filaments of BBD cyanobacteria fully embedded within an EPS matrix in the mature biofilm. CY: cyanobacteria, EPS: exopolysaccharides.

Figure 7. Layering of cyanobacterial filaments in parallel orientation on top of coral tissue at the interface between coral tissue and the mature BBD mat. CY: cyanobacteria

Figure 8. Cross-section of BBD cyanobacterial filaments aligned in parallel and fully embedded in a distinct layer of EPS. CY: cyanobacteria, EPS: extracellular polysaccharide. 
Figure 1.

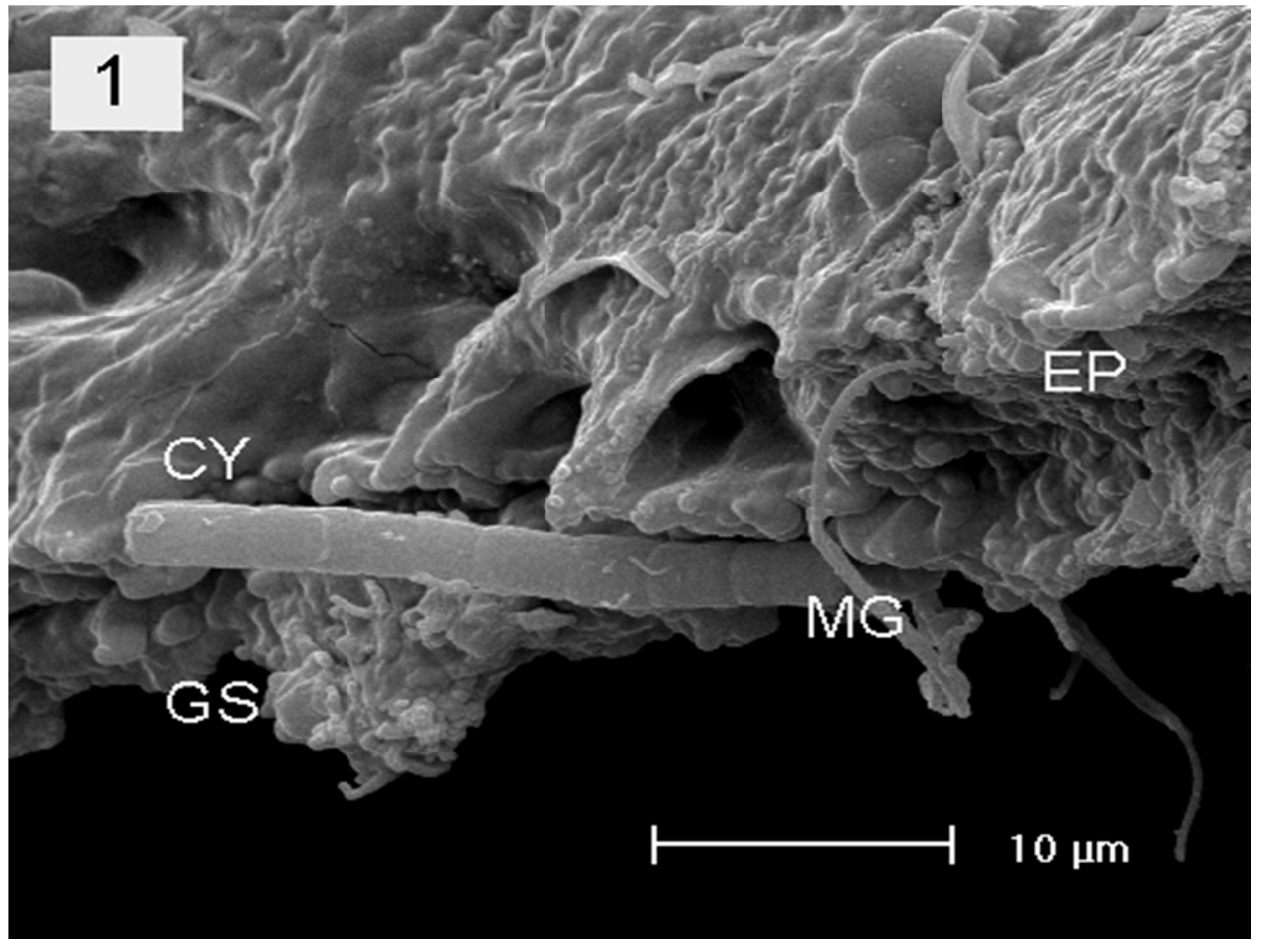


Figure 2.

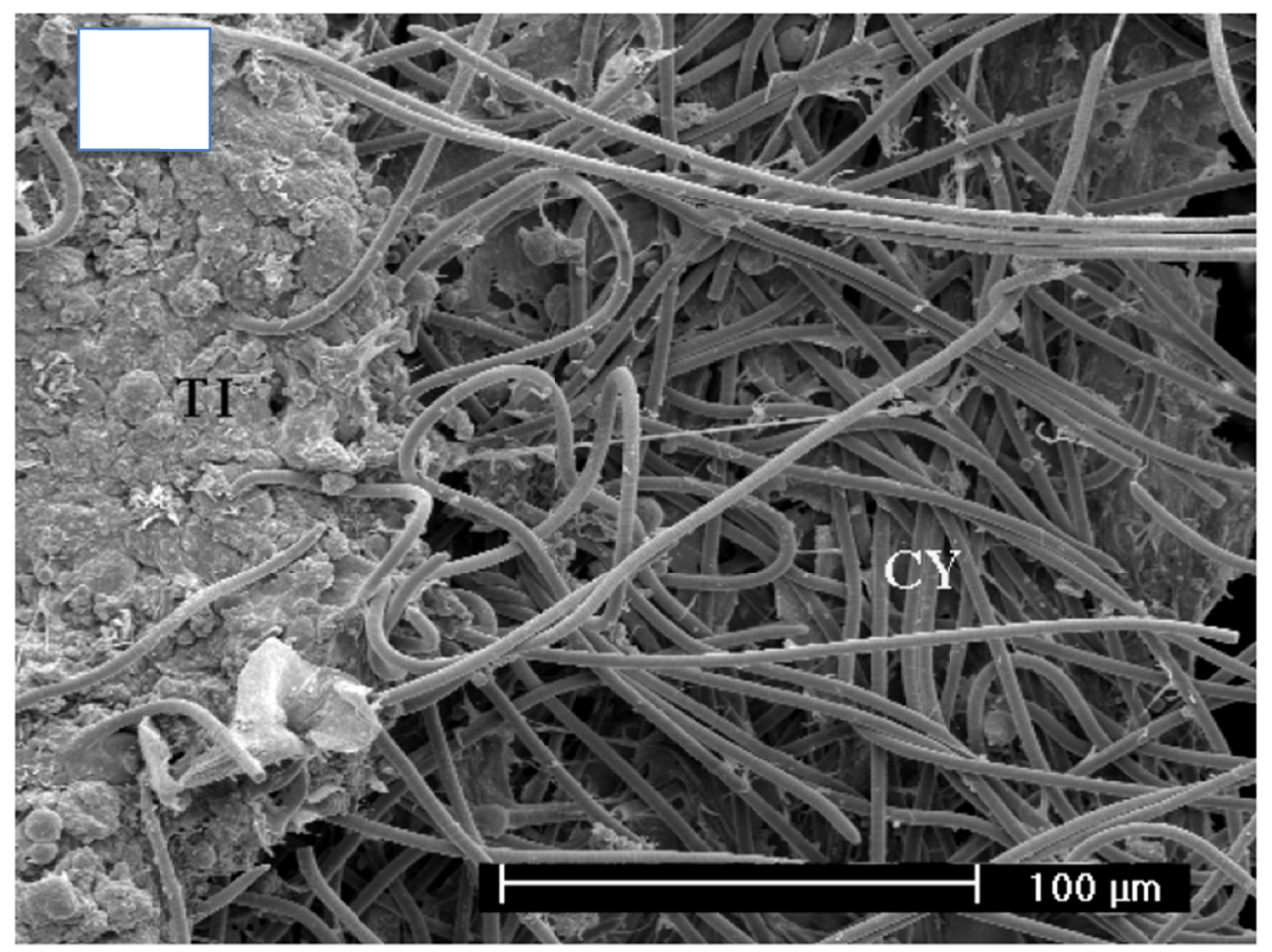


Figure 3.

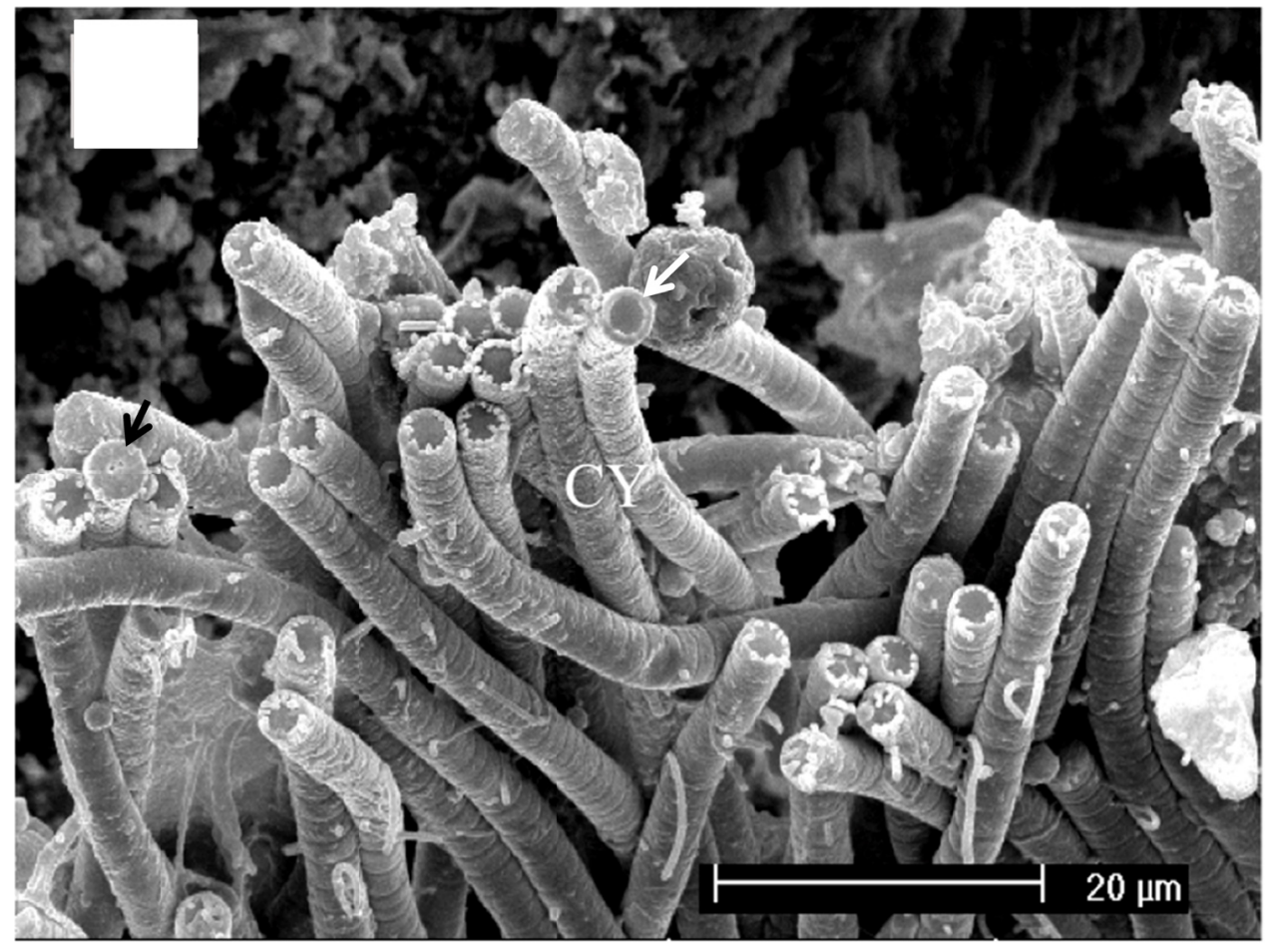


Figure 4.

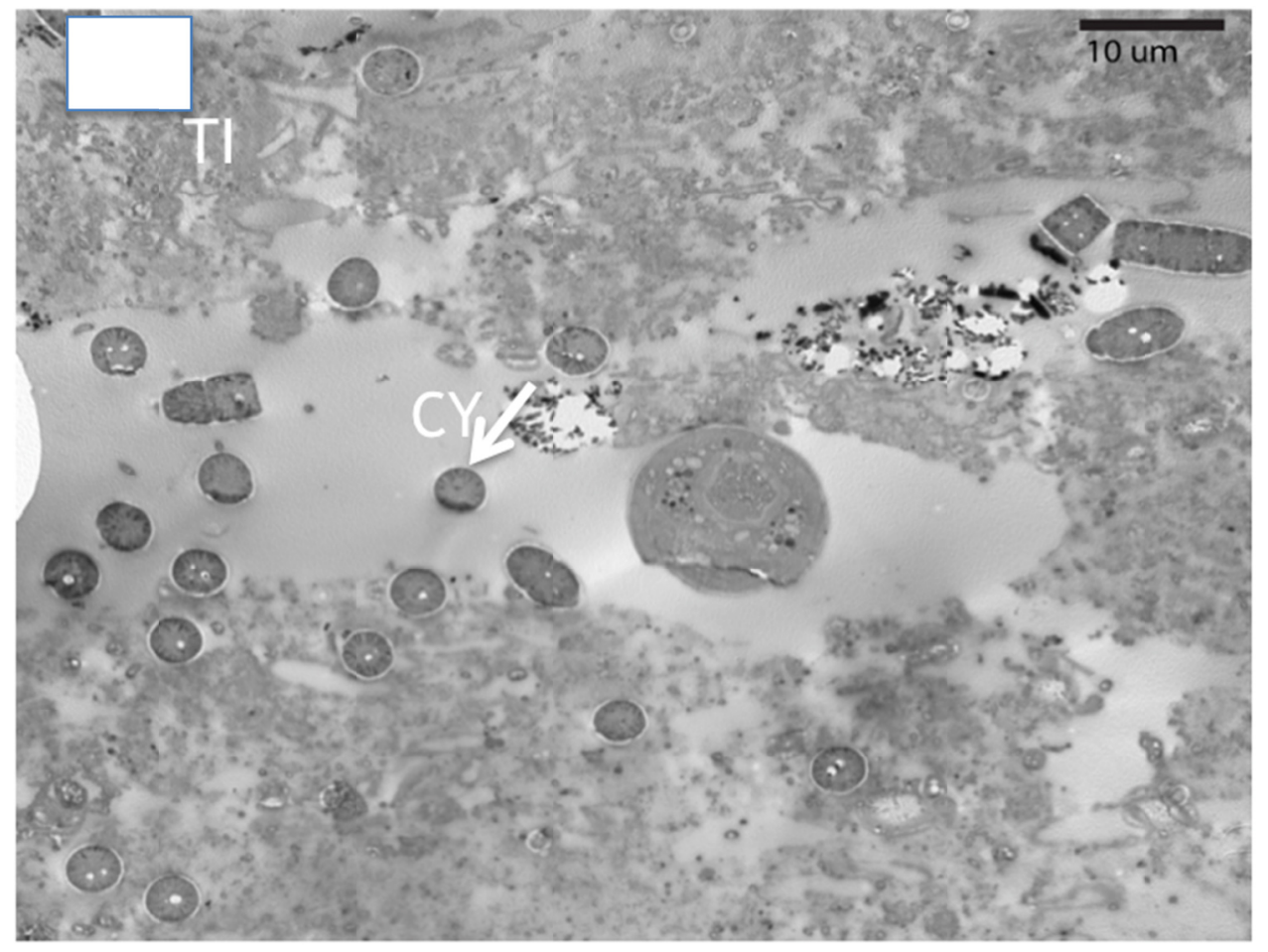


Figure 5.

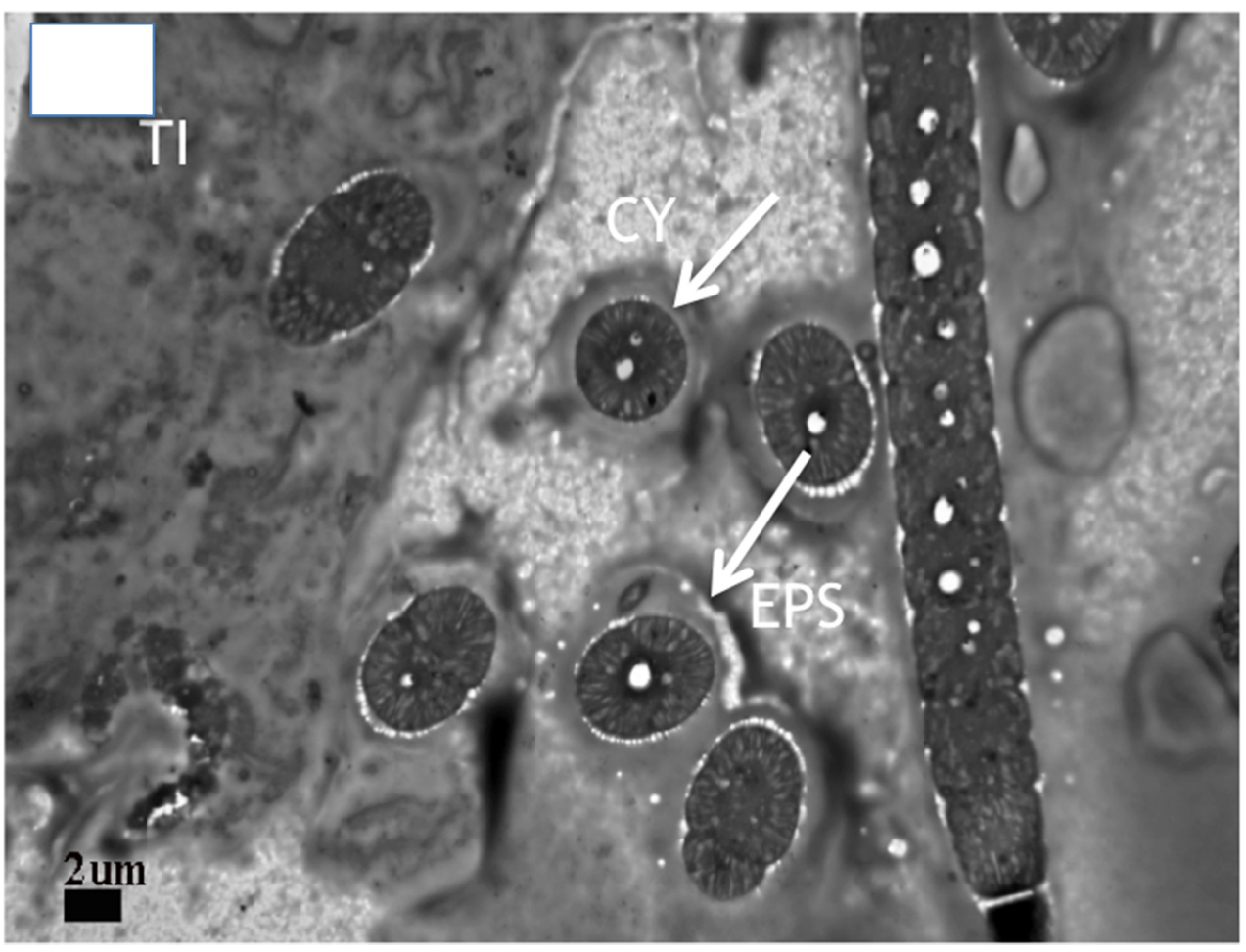


Figure 6.

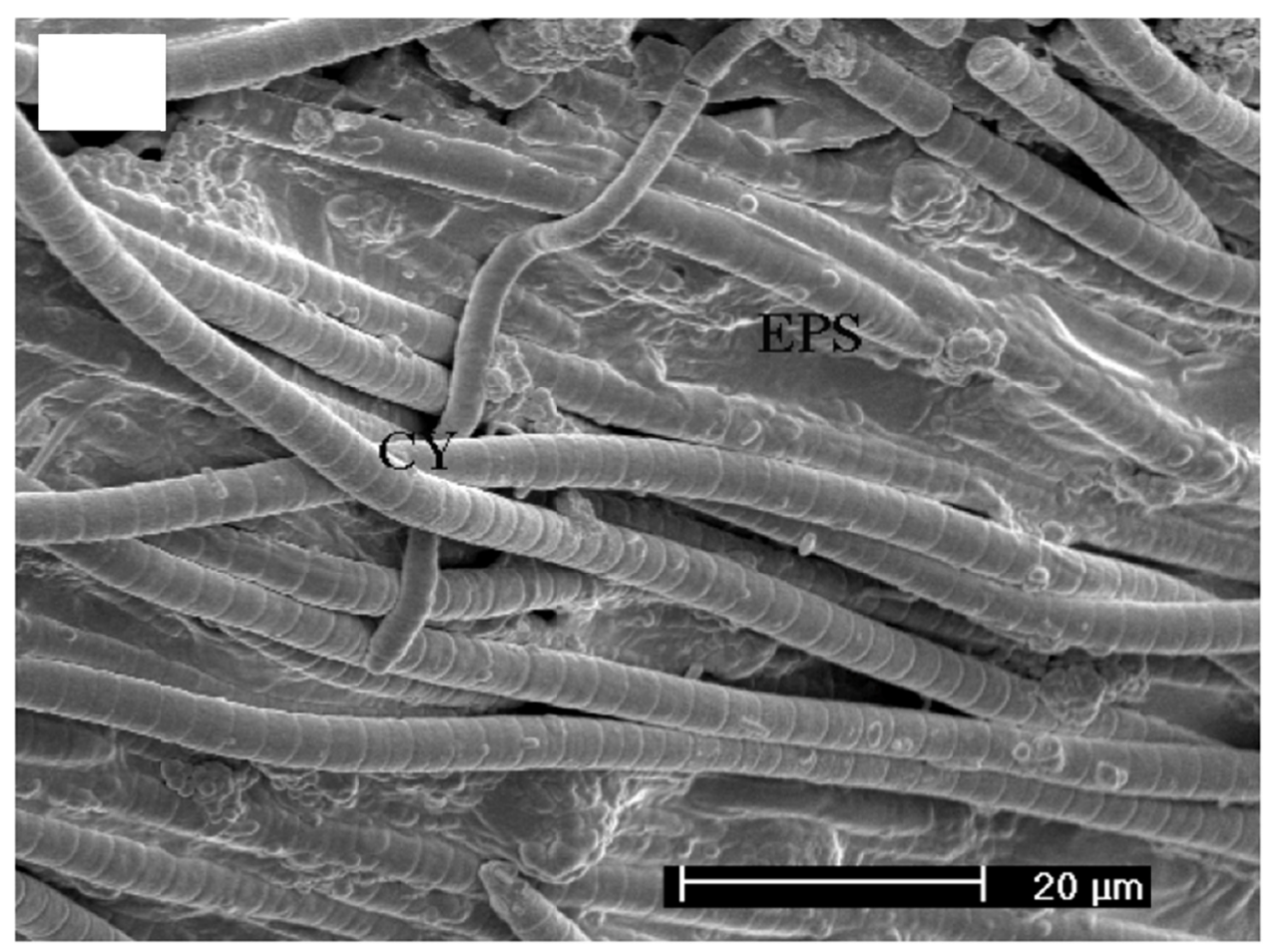


Figure 7.

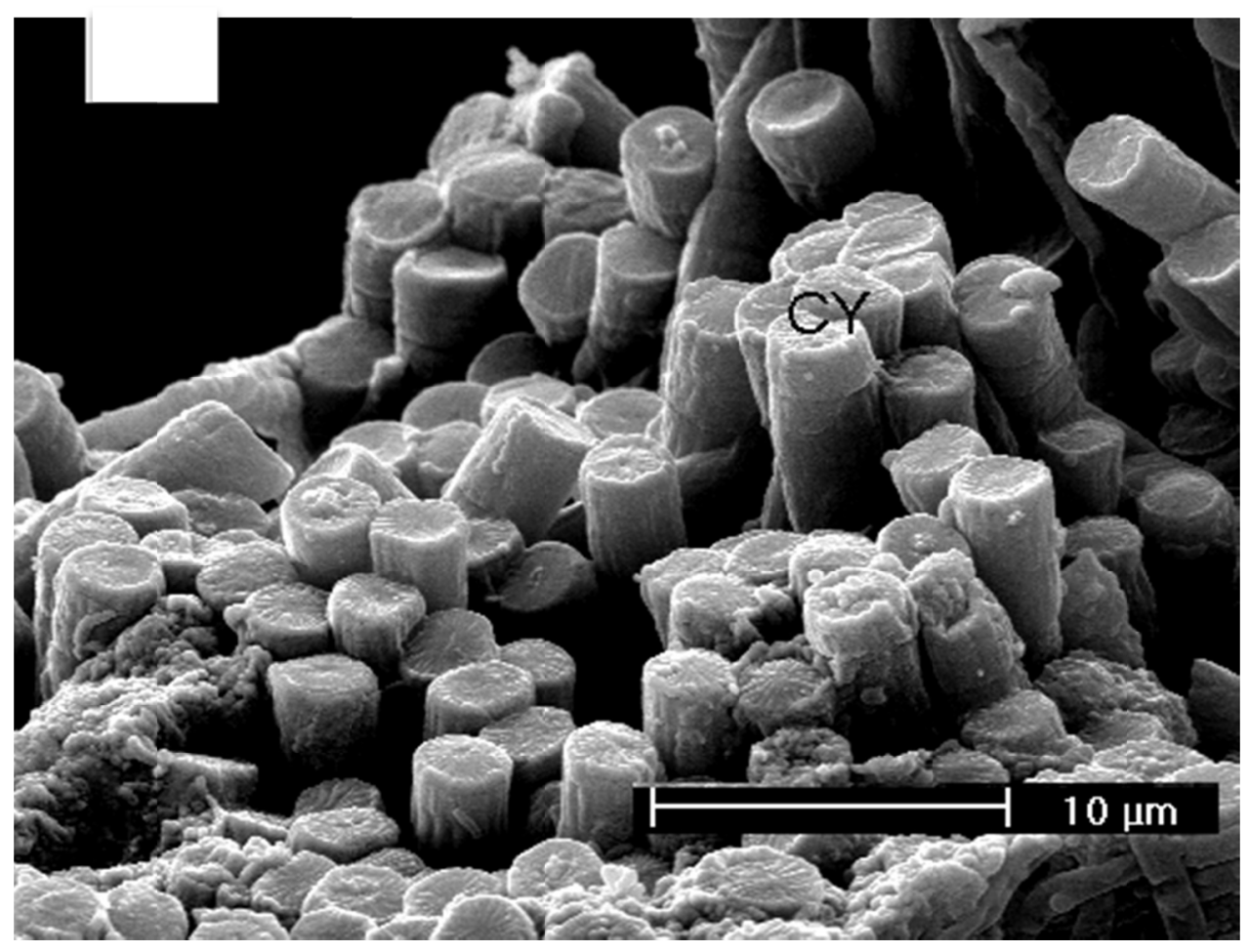


Figure 8.

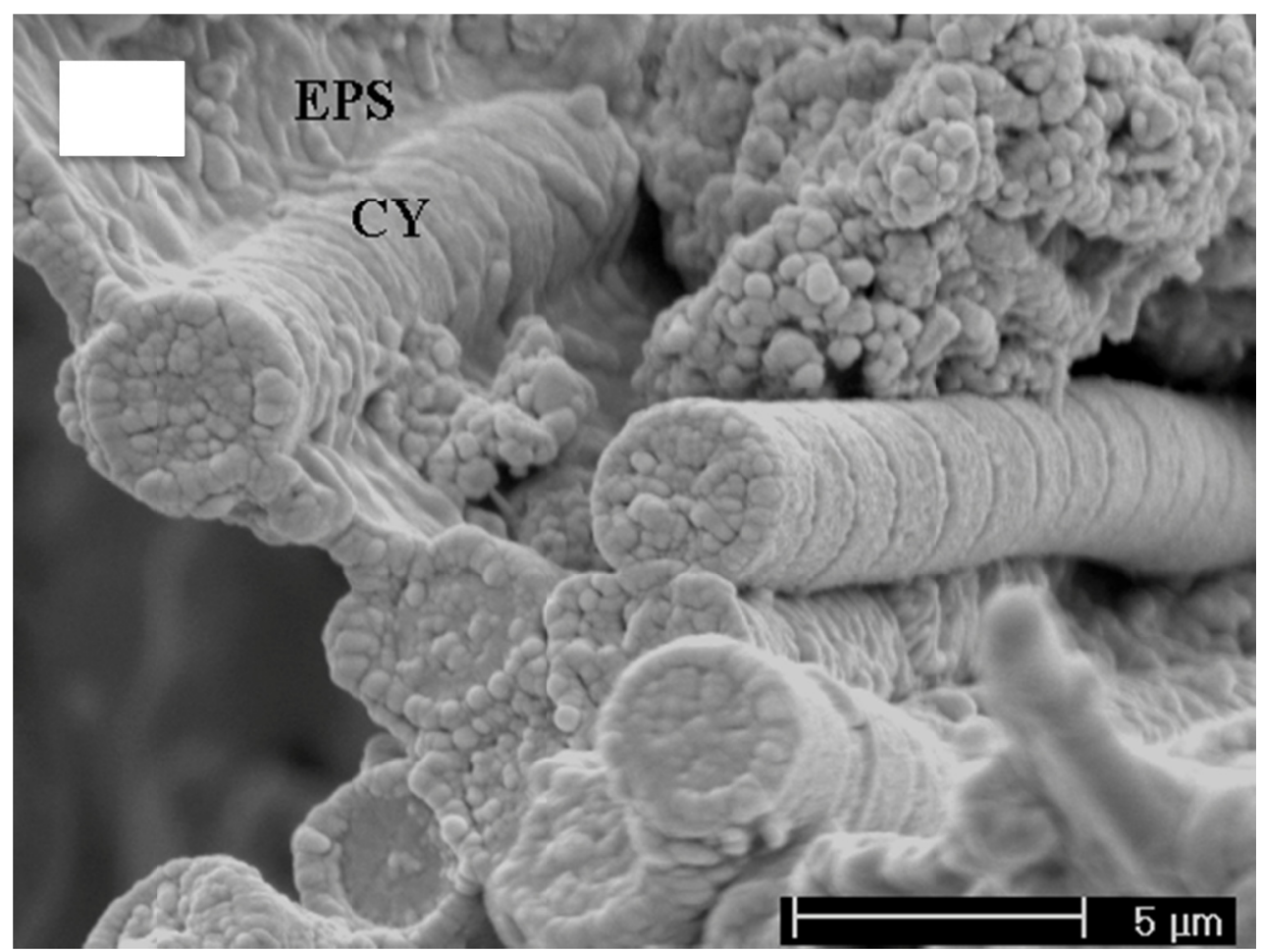




\section{CHAPTER VI}

\section{A CLIMATE-DRIVEN MODEL FOR THE INFECTION CYCLE OF BLACK BAND DISEASE}


Black band disease (BBD), the first coral disease discovered by the scientific community, is one of the most complex, damaging, and widespread of coral diseases. Because of the complexity of this disease, it has been difficult to establish the mechanisms involved in the infection process. Since its discovery in 1973, researchers have described many characteristics and correlations that are important to BBD processes. It is now possible to connect the disparate avenues of research on BBD to form a testable, cohesive model for BBD infection and pathobiological processes. In this chapter, a comprehensive model is discussed, which includes the emergence of BBD on a coral host, the beginning of infection, the infection process, and post-infection. The proposed model is useful for developing hypotheses about the mechanisms associated with BBD, and may help in predicting future effects of the disease on coral reefs.

The model is divided into six segments, or distinct parts of the model, as shown in Figure 1, which progress sequentially, eventually completing a cycle. The cyclical nature of the model is indicative of the developmental and seasonal attributes of the disease and is driven by climate variables that facilitate the emergence and recurrence of the disease.

The stages may be summarized as follows:

1. As ocean temperature regionally increase seasonally over years, as well as exponentially over decades, the environment shifts to one more favorable for microbial growth which, in turn, favors opportunistic pathogenicity of microorganisms. 
2. These may be part of the normal flora of corals and the surrounding environment.

3. As some of the potential pathogens increase in number and biomass, they create microenvironments conducive for the growth of additional potentially pathogenic microorganisms.

4. With continued mutual growth thee microorganisms eventually form a biofilm that constitutes BBD.

5. Once a mature biofilm is formed, it migrates across a coral host through progressive biofilm development, in a manner that is directly analogous to other, well-established models of biofilm development.

6. As temperatures are reduced, a lower temperature threshold is reached and the biofilm is disrupted. The residual populations of BBD pathogens remain in the immediate area on the coral host where the disease band was present, and can subsequently return to levels required for biofilm formation when (as in 1.) temperatures rise again in subsequent seasons.

There are several characteristics of the environment, the coral hosts, and the disease that are incorporated in above model. The supporting empirical evidence which fulfills these expected attributes, collected by many authors since the discovery of BBD, is provided for each aspect of the disease process, which taken together, converge to support the validity of the model. Figures 2-7 show each of the six segments and supporting evidence in graphical format. Each of these segments is discussed in detail below. 


\section{Segment 1 - Drivers of Coral Disease}

Different environmental factors have been correlated with numerous disease processes, and authors have suggested several specific factors that drive the emergence of coral disease (reviewed in Sutherland et al. 2004, Sokolow 2009). The most parsimonious interpretation of the data suggests that coral disease is not driven by a single factor, but rather is multifactorial. In addition, it is the result of many environmental variables interacting synergistically to facilitate the emergence of disease in an ecosystem that is vulnerable to changing conditions (Sokolow 2009). However, some environmental variations have a greater impact on the emergence of disease than others. In particular, it is suggested here that increasing ocean temperature both seasonally in the short-term, and over decades in the long-term is the primary driver behind coral disease in general, and of BBD specifically.

Approximately half of the 21 described coral diseases have been directly correlated with elevated temperatures, all of which are known or proposed to be caused by microorganisms (Sutherland et al. 2004, Weil et al. 2006). Epstein (2005) suggests that climate variability associated with climate change facilitates microbial growth, as is the case with emerging diseases such as Lyme disease and cholera. Harvell et al. (2002) have suggested that a warming climate may facilitate the proliferation of infectious diseases through an increase in the virulence of potential pathogens, in conjunction with an increase in host susceptibility. This mechanism has also been suggested as an important in facilitating coral disease specifically (Selig et al. 2006, Bruno et al. 2007, Harvell 
et al. 2007). It is now well-known that elevated temperatures have a significant negative effect on the coral holobiont. They can alter the microbial community associated with the surface mucopolysaccharide layer (SML) of corals, leading to a reduction in the proportion of the community that produces antimicrobial compounds (Ritchie 2006). These compounds may serve to protect healthy coral against infection (Rosenberg et al. 2007). A strong link has also been established between elevated temperatures and coral bleaching, which can be fatal if bleaching is sustained for more than a few days (Ainsworth et al. 2008; Coffroth et al. 1990; Williams and Bunkley-Williams 1990; Glynn 1991; HoeghGuldberg 1999; Fitt et al. 2001; Douglas 2003). Coral bleaching may occur either as the result of a temperature-induced breakdown in the symbiosis between the coral host and its zooxanthellae, termed "thermal" bleaching (Warner et al. 1999, Mitchelmore et al. 2002, Baird et al. 2009), or may be facilitated through a temperature-induced conversion of bacteria from the genus Vibrio to a pathogenic state, leading to "bacterial" bleaching (Kushmaro et al. 1997, 1998, 2001). It has also been shown that disease outbreaks can follow mass coral bleaching events, which would also be thermally-driven, even if indirectly (Bruno et al. 2007, Harvell et al. 2001, 2007).

Global temperatures have been increasing at an exponential rate, rising $0.9^{\circ} \mathrm{C}$ since 1850 , with $0.65^{\circ} \mathrm{C}$ of that occurring since 1965 (Brohan et al. 2006, Hansen et al. 2006). A similar trend has been shown for the oceans, which have increased between $1.2-1.6^{\circ} \mathrm{C}$ in many coastal regions since 1900 (Deser et al. 2010). Coral diseases were first discovered in 1973 (Antonius 1973). Since that 
time, the number of known diseases have increased exponentially, together with increasing prevalence, geographic distribution, and coral host range (Porter et al. 1999, Green and Bruckner 2000, Sutherland et al. 2004, Weil 2004, Sokolow 2009). The known distribution both for BBD and for coral disease in general has followed a pattern of initial observations in the Caribbean, and subsequently radiating out into the Indo-Pacific (Antonius 1973, 1985, Dustan 1977, Gladfelter et al. 1977, Dinsdale 1994, Sutherland et al. 2004, Weil et al. 2006). While these observations may be a result of increased sampling effort, a review of the literature suggests that they reflect an underlying trend as temperatures continue to rise (Sokolow 2009).

While many factors contribute to an increase in coral disease, including eutrophication, sedimentation, changes in light irradiance, elevated temperature, and others (reviewed in Sutherland et al. 2004), elevated temperature is the only factor that is global in distribution. Additionally, global warming follows a similar trend as the emergence of coral disease in general. As increased temperature is known to have significant negative effects both on the virulence of disease pathogens and on the coral holobiont itself, it may be the primary driver of coral disease in general, and of BBD specifically. Elevated temperatures have been tightly correlated with BBD processes globally, including an increase in prevalence (Antonius 1981, Edmunds 1991, Kuta and Richardson 1996, Bruckner and Bruckner 1997, Kuta and Richardson 2002, Willis et al. 2004, Borger and Steiner 2005), progression, and transmission between colonies (Boyett et al. 2007, Sato et al. 2011), as well as increased growth of associated 
cyanobacteria isolated from BBD (Rützler and Santavy 1983, Carlton and Richardson 1995, Kuta and Richardson 2003, Voss and Richardson 2006, Myers et al. 2007). The concept that elevated temperatures drive the emergence of BBD will serve as the basis for all subsequent segments of the model discussed below.

\section{Segment 2 - Reservoirs of BBD Pathogens}

There has been significant debate as to the identity of a primary pathogen, or pathogens, associated with BBD (Garrett \& Ducklow 1975, Ducklow and Mitchell 1979, Rützler and Santavy 1983, Taylor 1983, Cooney et al. 2002, FriasLopez et al., 2002, 2003, 2004, Sekar et al. 2006, 2008, 2009, Sussman et al. 2006, Arotsker et al., 2009, Rasoulouniriana et al. 2009, Stanić et al. 2011). Considerably less attention has focused on the reservoirs of the microorganisms within the BBD consortium.

Evidence suggests that BBD cyanobacteria originate from the populations of cyanobacteria present within the endolithic community. Live corals harbor a significant and diverse community of epilithic, endolithic, and intracellular cyanobacteria that differ from the community associated with dead coral skeleton (Le Campion-Alsumard et al. 1995, Radtke et al. 1997, Lesser et al. 2004, Tribollet 2008). In Chapter 3, it was shown that cyanobacteria from the BBD mat of both naturally- and artificially-infected corals exhibit significant boring through the coral skeleton, which appeared in patches throughout the skeleton and underneath infected tissue. It was also shown that these cyanobacteria emerge from within the coral skeleton to penetrate into the coral tissue above. Coral 
tissue penetration by cyanobacteria associated with BBD has also been shown to occur by several other investigators (Rützler et al. 1983, Barneah et al. 2007, Sato et al. 2009a).

On the Great Barrier Reef, corals harboring non-pathogenic cyanobacterial patches were shown to be infected by BBD through successional changes in the cyanobacterial community that included the new appearance of cyanobacterial taxa known to be associated with BBD (Sato et al. 2009a). In order for these successional changes to occur, a source of the BBD cyanobacteria must be available, seeding the non-pathogenic patches with an increasing population of the potentially pathogenic BBD cyanobacteria. The most likely source of the BBD cyanobacteria would be the coral skeleton or coral tissue.

In support of the proposal that the coral skeleton is the source of pathogenic BBD cyanobacteria, it has been shown using histopathology that corals macroscopically exhibiting symptoms consistent with white band disease were shown to harbor a cyanobacterial community similar to BBD deep within the coral polyps, which the authors termed 'atypical BBD' (Ainsworth et al. 2007). However, these observations could also be interpreted as a stage of BBD maturation whereby the successional development that leads to BBD can also occur within the coral skeleton, and become pathogenic before a conspicuous biofilm develops on the coral. This interpretation is corroborated by Antonius (1981) who reported that BBD can start as a dark circle underneath coral tissue, eventually developing into a mature infection. 
To further support the idea that the BBD-cyanobacteria are endolithic, it has been shown that the artificial infection of corals with BBD requires wounding of the coral tissue (Aeby and Santavy 2006). If the BBD cyanobacteria originate from the endolithic community of corals, and cannot penetrate through the epidermis from the outside (Rützler et al. 1983), then wounding would be required to access the coral skeleton. It has been found that the most prevalent BBD cyanobacterium, Roseofilum reptotaenium (Casamata et al. 2011), occurs frequently on healthy corals in reefs in Curaçao detected in a slurry of coral mucus, tissue, and skeleton (Klaus et al. 2007, 2011). Together, these lines of evidence suggest that the BBD cyanobacteria originate from within the coral skeleton. A previous study showed that the cyanobacteria associated with BBD were found in sediment-filled depressions on apparently healthy corals (Richardson 1996a). As sediment accumulates on a coral colony containing endolithic, BBD-associated cyanobacteria, the cyanobacteria could populate the sediment patch, and possibly facilitate infection. However, this mechanism of infection has yet to be observed. It is suggested here that because the endolithic community harbors a diverse cyanobacterial population, and the most prevalent BBD cyanobacterium is common on healthy corals in at least some regions, that a proportion of apparently healthy corals harbor these endolithic potential pathogens, which with the appropriate environmental conditions, can lead to BBD outbreaks.

Black band disease is a complex and variable polymicrobial biofilm with a number of functional groups other than cyanobacteria contributing to its 
pathogenesis (Richardson et al. 1997, Cooney et al. 2002). This brings into question where the other members of the microbial consortium originate. Many clone libraries have been constructed from black band disease samples from a variety of host species and geographic regions (Cooney et al. 2002, Frias-Lopez et al. 2002, 2003, 2004, Sekar et al. 2006, 2008, 2009, Sussman et al. 2006, Viehman et al. 2006, Barneah et al. 2007, Myers et al. 2007, Arotsker et al. 2009, Sato et al. 2009a). Chapter 2 presented a meta-analysis of these studies, which allowed for taxonomic and functional trends within the BBD consortium to become apparent. If BBD were caused by bacteria from the immediate environment, it is expected that there would be regional specificity in the microbial consortium, and that the members of the pathogenic consortium would be common in the coral host, or the surrounding seawater/sediments. This regional specificity is evident both in Chapter 2, Figure 4, and in another study using length heterogeneity PCR (LH-PCR) from BBD-infected corals in three different regions of the Caribbean (Voss et al. 2007). In each case, there was greater regional specificity than coral host species specificity, suggesting either that the environment surrounding the coral provides a significant source of members of the BBD community, or that the microbiota of the corals also exhibit some regional specificity.

Chapter 2 shows that the alpha-proteobacteria are the most diversely represented within clone libraries constructed from 87 BBD samples (Figure 2), and specific operational taxonomic units (OTUs) from this taxa are among the most numerous. This includes two OTUs present in $13 \%$ of the clone libraries, 
the second most prevalent of all OTUs in the BBD samples, following the sequence for $R$. reptotaenium present in $71 \%$. Alphaproteobacteria are common symbionts of marine invertebrates (Shiba 1991, Lafay et al. 1995, Ashen and Goff 1996, Barbieri et al. 1996, Burnett and McKenzie 1997). They are the most diverse and abundant microbial taxa in marine waters (Gonzalez and Moran 1997, Giovannoni and Stingl 2005, Pommier et al. 2007, Biers et al. 2009), and are among the most diverse and abundant on healthy coral hosts (Rohwer et al. 2001, 2002, Bourne and Munn 2005). The second most diversely represented group in BBD, the gamma-proteobacteria, exhibit a similar distribution, both in marine waters and in coral hosts (Rohwer et al. 2001, 2002, Bourne and Munn 2005, Giovannoni and Stingl 2005, Pommier et al. 2007, Biers et al. 2009). The sulfate-reducing bacteria are an important functional group within BBD in terms of the disease etiology. They produce the toxic sulfide that contributes to tissue lysis (Chapter 3, Richardson et al. 2009). These bacteria are common in the top centimeters of sediment in coral reef ecosystems (Skyring and Chambers 1976), and dominate in marine anaerobic zones, where they oxidize up to $50 \%$ of total organic carbon (Howarth \& Hobbie 1982, Jørgensen 1982). Another important functional group in BBD, the sulfide-oxidizers, is also ubiquitous in marine sediments, often accompanying the sulfate-reducing bacteria (Nealson 1997).

In addition to $R$. reptotaenium, specific OTUs that are repeatedly found in BBD represent genera that are common in the immediate marine environment of the coral hosts. One OTU present in $13 \%$ of the 87 clone libraries constructed from BBD, was identified as belonging to the Cytophaga genus, which is 
common to marine sediments (Chapter 2, Cooney et al. 2002). Another OTU present in $13 \%$ of the clone libraries, Roseovarius crassotreae, is also the etiological agent of Roseovarius Oyster Disease (ROD) (Boettcher et al. 2005, Maloy et al. 2007). One OTU (7\% of clone libraries) belonging to the genus Roseobacter, belongs to the same family as R. crassotreae, and is also found to comprise greater than $20 \%$ of the marine bacterioplankton of coastal waters (Chapter 2, Buchan et al. 2005). OTUs from the genus Vibrio are another common group found in BBD. Bacteria from the genus Vibrio are ubiquitous in marine waters, and show seasonal variations in diversity (Thompson et al. 2004). Vibrios are important pathogens in other coral diseases that include bacterial bleaching, white plague, and yellow blotch/band disease (Kushmaro et al. 1996, 1997, Ben-Haim and Rosenberg 2002, Ben-Haim et al. 2003a,b, Cervino et al. 2004, Arotsker et al. 2009, Sunagawa et al. 2009).

In addition to the abundance of BBD-associated bacteria in the immediate environment of coral hosts, other lines of evidence suggest that they are part of the immediate environment and become opportunistically pathogenic with changing environmental conditions. Some of the OTUs that are abundant in BBD are also found at low populations on healthy corals (Frias-Lopez et al. 2004), suggesting that the growth of these populations is favored by the conditions associated with BBD. BBD-infected corals from sewage-impacted sites are found to contain high numbers of sewage-associated bacteria (FriasLopez et al. 2002, Sekar et al. 2008), which would be expected if bacteria from the immediate environment contribute to the BBD consortium. When aquarium- 
maintained coral fragments are artificially infected with a non-axenic culture of $R$. reptotaenium, over the course of a few days an active suluretum develops on the coral, which is required for BBD (Stanić et al. 2011), despite the fact that the corals were acclimated to, and infected in, artificial seawater. This suggests that the other BBD consortium bacteria must have originated from within the coral itself.

The idea that BBD-associated bacteria are originating from the coral and the immediate reef environment is not exclusive from the idea that corals are cross-infected from other infected corals. The BBD mat is loosely adhered to the coral colony and can be easily dislodged with wave action. This can lead to clumps of the biofilm sloughing off and possibly coming in contact with other coral colonies, where it may adhere once again and initiate infection. Black band disease is easily transmitted this way artificially, and BBD infections have been shown to exhibit a clumped distribution that follows ocean currents (Bruckner et al. 1997, Page and Willis 2006), suggesting that this type of transmission occurs on the reef.

\section{Segment 3 - Pathogenesis}

As stated previously, evidence suggests that the bacteria associated with $\mathrm{BBD}$ are part of the normal flora of corals and the surrounding environment, and that it is the changing environmental conditions that favor the growth of these pathogens, leading to disease. In particular, elevated temperatures are believed to be the primary driver, but increased nutrients also play a role. 
While elevated temperatures have been correlated to numerous BBD processes, elevated nutrients have also been correlated with increased BBD progression (Voss and Richardson 2006), and may override the effects of decreasing temperatures in reducing BBD processes (Rodriguez and Cróquer 2008). It is expected that if elevated temperatures and nutrients increase the disease processes associated with the consortium as a whole, thus facilitating the metabolic processes of the individual members of the consortium, that these conditions also facilitate the growth of the associated bacteria when not living in the BBD community. Cyanobacteria isolated from BBD have been shown to exhibit temperature dependent growth with optima at elevated temperatures that are above the observed threshold on the reef of $27.5^{\circ} \mathrm{C}$ (Rützler and Santavy 1983, Taylor 1983, Carlton and Richardson 1995, Kuta and Richardson 2003, Voss and Richardson 2006, Myers et al. 2007). No significant effect of growth between 27 and $30^{\circ} \mathrm{C}$ was found with $R$. reptotaenium (Stanić et al. 2011), suggesting an optimum temperature below what was found as the threshold for the emergence of BBD on the reef. The same strain was found to have a temperature optimum of $25^{\circ} \mathrm{C}$, when assessed also at 22 and $30^{\circ} \mathrm{C}$ (Rasoulouniriana et al. 2009). As temperatures increase seasonally, the microbial composition associated with both the seawater, and the coral holobiont is altered. The bacteria associated with BBD are likely to be among those favored to grow.

Additional lines of evidence suggest that as the microbial composition associated with corals shifts with environmental variation, particular functional 
groups are favored to grow, which then facilitate the growth of other functional groups. Several strains of cyanobacteria have been isolated from BBD, including those from the genera Geitlerinema, Leptolyngbya, and Roseofilum. In each of the strains that were examined, the cyanobacteria were capable of sulfideresistant, oxygenic photosynthesis (Richardson and Kuta 2003, Myers et al. 2007), which is a rare characteristic among cyanobacteria (Cohen et al. 1986, Garcia-Pichel and Castenholz 1990). This suggests that as sulfate-reducing bacteria increase in population, producing sulfide, the cyanobacteria that may cause BBD are provided an advantage over those that cannot tolerate the level of sulfide produced. This would lead to a more homogenous population of cyanobacteria, favoring potentially pathogenic strains. However, in addition to potentially pathogenic strains, it would favor other non-pathogenic cyanobacteria capable of growth under these conditions. Indeed, some strains of cyanobacteria that have been isolated from BBD cannot infect corals (Stanić et al. 2011). Similarly, it has been shown that exposure to microcystin, produced by BBD cyanobacteria (Richardson et al. 2007), can facilitate or inhibit the growth of bacteria associated with BBD and the SML of corals (Richardson et al. 2009), further structuring the BBD community as the cyanobacteria increase in population. While most of the cyanobacteria isolated from BBD decrease the amount of microcystin produced with elevated temperatures (Gantar et al. 2009), no change in production was observed for Roseofilum when exposed to elevated temperatures (Stanić et al. 2011). 
Additional evidence that changing environmental conditions facilitate the growth of the pathogenic biofilm comes from the fact that the BBD biofilm is similar, both in species and chemical composition, to those found in extreme environments such as hot spring outflows, and hypersaline ponds (Carlton and Richardson 1995). Populations of cyanobacteria in these extreme environments live in conditions that facilitate biofilm formation. Those inhabiting the endolithic community of corals may have the potential to produce biofilms, but live in conditions that do not support biofilm formation. With changing environmental conditions that facilitate the growth of bacteria such as the cyanobacteria and sulfate-reducers, the formation of a biofilm may then be supportable, which can lead to BBD.

\section{Segment 4 - Biofilm Formation}

The evidence suggests that as potentially pathogenic bacteria associated with corals or their immediate environment increase in population and facilitate the growth of other potentially pathogenic bacteria, they eventually reach a threshold population level, and, through quorum sensing, up-regulate biofilmforming genes. It has previously been suggested that cyanobacteria-dominated biofilms such as BBD require inter-specific quorum sensing (Decho et al. 2010). When a portion of the BBD mat is removed from an infected coral, and suspended in seawater next to the colony, it exhibits differential gene expression relative to the attached biofilm, including genes associated with virulence factors in Gram-negative bacteria (Frias-Lopez et al. 2004). Further evidence for this 
biofilm formation comes from the successional development of BBD from nonpathogenic cyanobacterial patches discussed previously (Sato et al. 2009a).

In other instances, BBD can develop as a dark circle underneath the coral tissue, that eventually forms a ring that radiates out, lysing coral tissue (Antonius 1981). The latter form of development may be the result of succession within the coral skeleton itself, before the biofilm radiates out onto the surface of the coral, and therefore, may be a variation of the same process. The endolithic succession may also occur at a demarcation between exposed coral skeleton and coral tissue, leading to 'atypical' BBD (discussed in segment 2).

As BB-disease develops, it occurs in isolated areas on the infected coral colony, migrating outwards, consuming coral tissue as it proceeds. Because the endolithic cyanobacterial community associated with corals has been shown to be a diverse community (Le Campion-Alsumard et al. 1995, Radtke et al. 1997, Tribollet 2008), there cannot be a single population of cyanobacteria that is homogeneously distributed throughout the endoskeleton. It follows then that the heterogeneous distribution of cyanobacteria in the coral skeleton is what can lead to the isolated areas of infection on a host coral colony. In Chapter 3, it was shown that the cyanobacteria associated with BBD bore through the skeleton, and penetrate into the coral tissue from the skeleton, supporting the idea of development from within. In addition to this, the bore holes that were produced were grouped and sporadic. Thus, pockets containing greater densities of BBDcyanobacteria within the coral skeleton may seed the pathogenic biofilm as it migrates over those areas once the disease has matured, in addition to initiating 
the disease itself. Healthy corals were also shown to exhibit some bore holes of similar size to those caused by the cyanobacteria in infected corals, but these were far fewer in number, and were not clustered, and no cyanobacteria were seen on the surface of the coral (Chapter 3). This gives further support to coral skeleton origination, showing that cyanobacteria can penetrate to the surface, even in apparently healthy corals.

\section{Segment 5 - Pathobiology}

The formation of cyanobacteria-dominated biofilms is common in many environments. However, the migration and pathogenesis of a cyanobacteriadominated biofilm on an animal substrate is unique to BBD (Richardson 1996b). Chapters 3,4 , and 5 provide evidence suggesting that the BBD mat migrates across the coral host through progressive biofilm development, which is facilitated through toxin production. Other authors who showed that the cyanobacteria from BBD can penetrate into coral tissue, have suggested that coral tissue lysis may be facilitated by chemical histolysis (Rützler et al. 1983, Barneah et al. 2007, Sato et al. 2009).

In agreement with Rützler et al. (1983), Chapter 4 showed that two toxins found in BBD, microcystin and sulfide, can cause tissue lysis that is both qualitatively and quantitatively similar to what occurs in BBD. Lysis occurred in 18-22 hours, which is the same amount of time that it takes for a BBD infection to pass over a fixed point on a coral colony (Richardson et al. 1997). The effect that BBD toxins have on coral tissue suggests that as the polymicrobial biofilm develops, including the active sulfuretum from the sulfate-reducing and sulfide- 
oxidizing bacteria present in BBD (Richardson and Carlton 1993), it provides a chemical means to aid in tissue destruction, facilitating tissue penetration by the cyanobacteria.

After a mature biofilm is established, the BBD community migrates across the coral host, causing tissue lysis along the way. Cyanobacteria in BBD can move ahead of the mature BBD band via two different mechanisms. The first is that the cyanobacteria are able to migrate horizontally through the mesoglea, which is the coral tissue layer with least resistance. This proceeds progressively as individual cyanobacteria move through the mesoglea, and accumulate in clusters exhibiting differential extracellular polysaccharides (EPS) secretion and orientation, eventually maturing into new biofilm (Chapter 5), and is analogous to the development of other biofilms primarily composed of unicellular bacteria, although there are distinct differences between BBD development and the other model systems (Costerton et al. 1999, Chapter 5). The second mechanism is that as the cyanobacteria penetrate through the mesoglea, the coral tissue layers separate, and the epidermis can slough off. This leads to bundles of epidermis ahead of the band that are packed full of cyanobacterial filaments (Chapter 3). This second mechanism would facilitate the first, and also leads to the epidermis being progressively degraded within the polymicrobial consortium, which has also been shown previously (Rützler et al. 1983).

\section{Segment 6 - Post Infection}

Black band disease occurs seasonally, re-infecting corals each year, and disappearing in cooler seasons (Edmunds 1991, Kuta and Richardson 1996, 
Bruckner et al. 1997). As seasonal conditions that facilitate the development of the biofilm community on coral (primarily elevated temperatures) decline when temperature is reduced, this may lower the metabolic functions of the BBD community, reducing its capacity to maintain the diverse consortium. Thus as temperatures recede, so does the disease. Because the cyanobacteria are able to penetrate into coral tissue and skeleton, when the disease ceases migration at the end of the season, there is likely to be a relatively concentrated population of the pathogenic cyanobacteria, and other bacteria associated with the consortium, within the coral tissue and/or skeleton, existing more as individual microorganisms rather than a biofilm. Then, as favorable conditions return the following season, the relevant populations may return, initiating the disease once again in the same area where it receded at the end of the previous season. Thus, the cycle continues back to segment one, the drivers of the disease. Black band disease, and coral disease in general, was unknown in the scientific community until 1973 (Antonius 1973). Since that time, the number of known coral diseases, as well as the prevalence, geographic distribution, and coral host range, has increased exponentially (Porter et al. 1999, Green and Bruckner 2000, Sutherland et al. 2004, Weil 2004). The model presented here offers an explanation as to why this may occur. It suggests that, at least for BBD, as ocean temperatures increase, the environment shifts to become more favorable towards microbial growth, which in turn, favors the opportunistic pathogenicity of microorganisms that are part of the normal flora of corals. This 
would favor a positive feedback loop, whereby infections can spread between colonies, which then become re-infected in subsequent disease 'seasons'.

With this model, it is also expected that as marine temperatures increase differentially between ocean regions (Deser et al. 2010), BBD should exhibit a differential emergence. BBD was discovered in 1973 in the Caribbean (Antonius 1973), in the Philippines and Red Sea between 1981 and 1984 (Antonius 1985), and in the Great Barrier Reef in 1994 (Dinsdale 1994). This follows the overall trend of rising sea surface temperature in the global oceans whereby the greatest warming $\left(1.2-1.6^{\circ} \mathrm{C} /\right.$ century $)$ has been seen directly east of the continents of the northern hemisphere, corresponding to the area encompassing the Caribbean, with a lower rise $\left(0.8-1.0^{\circ} \mathrm{C} /\right.$ century) in the Eastern Pacific and tropical Indian Oceans, corresponding to the area encompassing the Great Barrier Reef (Deser et al. 2010). However, it is also likely that the differential coral diversity between these regions may also contribute to this trend, as has been shown on a more local scale (Kuta and Richardson 2002, Kaczmarsky et al. 2005). With increasing coral diversity, this would provide a buffer to disease outbreaks as BBD-susceptible coral species may be spaced further apart, reducing the spread of the disease, and/or those corals harboring the potentially pathogenic cyanobacteria may be spaced further apart, also limiting its spread.

The ongoing trend of increasing coral disease is predicted to lower coral fecundity, and significantly alter the structure of the coral reef community (Edmunds 1991, Bruckner and Bruckner 1997). The evidence for the causes of $\mathrm{BBD}$, and coral diseases in general (including coral bleaching) increasingly 
suggest that the most effective means of mitigating the losses of coral reefs worldwide is the mitigation of climate change itself. 


\section{References}

1. Aeby G, Santavy D (2006). Factors affecting susceptibility of the coral Montastraea faveolata to black band disease. Mar Eco Prog Ser 318: 103110.

2. Ainsworth TD, Kramasky-Winter E, Loya Y, Hoegh-Guldberg O, Fine M (2007). Coral disease diagnostics: What's the difference between a plague and a band? Appl and Envir Microbiol 73(3): 981-992.

3. Ainsworth TD, Hoegh-Guldberg O, Heron SF, Skirving WJ, Leggat W (2008). Early cellular stress are indicators of pre-bleaching thermal stress in the coral host. J Exp Mar Biol and Ecol 364(2): 63-71.

4. Al-Moghrabi S (2001). Unusual black band disease outbreak in the northern tip of the Gulf of Aqaba. Coral Reefs 19(4): 330-331.

5. Antonius A (1973). New observations on coral destruction in reefs. 10th Meet Assoc Isl Mar Lab Carib 10: 3.

6. Antonius A (1981). The "band" diseases in coral reefs. Proc $4^{\text {th }}$ Int Coral Reef Symp 7-14.

7. Antonius A (1985). Coral diseases in the Indo-Pacific: A first record. Mar Eco 6(3): 197-218.

8. Arotsker L, Siboni N, Ben-Dov E, Kramasky-Winter E, Loya Y, Kushmaro A (2009). Vibrio sp. as a potentially important member of the black band disease consortium in Favia sp. corals. FEMS Microbio Eco 70(3): 515524.

9. Ashen JB, Goff LJ (1996). Molecular identification of a bacterium associated with gall formation in the marine red alga Prionitis lanceolata. $\mathrm{J}$ of Phyco 32: 286-297.

10. Baird AH, Bhagooli R, Ralph PJ, Takahashi S (2009). Coral bleaching: The role of the host. Trends in Eco and Evol 24(1): 16-20.

11. Barbieri E, Gulledge J, Moser DP, Chien CC (1996). New evidence for bacterial diversity in the accessory cnidamental gland of the squid Loligo pealei. Biol Bull 191: 316-317.

12. Barneah O, Ben-Dov E, Kramarsky-Winter E, Kushmaro A (2007). Characterization of black band disease in Red Sea stony corals. Environ Microbiol 9: 1995-2006. 
13. Ben-Haim $Y$, Rosenberg E (2002). A novel Vibrio sp. pathogen of the coral Pocillopora damicornis. Mar Biol 141(1): 47-55.

14. Ben-Haim Y, Thompson FL, Thompson CC, Cnockaert MC, Hoste B, Swings J, Rosenberg E (2003) Vibrio corallyticus sp. nov. a temperaturedependent pathogen of the coral Pocillopora damicronis. IJSEM 53(1): 309-315.

15. Ben-Haim Y, Zicherman-Keren M, Rosenberg E (2003). Temperatureregulated bleaching and lysis of the coral Pocillopora damicornis by the novel pathogen Vibrio corallyticus. Appl Envir Microbiol 69(7): 4236-4242.

16. Biers EJ, Sun S, Howard EC (2009). Prokaryotic genomes and diversity in surface ocean waters: Interrogating the global ocean sampling metagenome. Appl Environ Microbiol 75(7): 2221-2229.

17. Boettcher KJ, Geaghan KK, Maloy AP, Barber BJ (2005). Roseovarius crassotreae sp. nov., a member of the Roseobacter clade and the apparent cause of juvenile oyster disease in cultured Eastern oysters. IJSEM 55(4): 1531-1537.

18. Borger JL, Steiner CC (2005). The spatial and temporal dynamics of coral disease in Dominica, West Indies. Bul of Mar Sci 77(1): 137-154.

19. Bourne DG, Munn CB (2005). Diversity of bacteria associated with the coral Pocillopora damicornis from the Great Barrier Reef. Environ Microbiol 7(8): 1162-1174.

20. Boyett HV, Bourne G, Willis BL (2007). Elevated temperature and light enhance progression and spread of black band disease on staghorn corals of the Great Barrier Reef. Mar Biol 151: 1711-1720.

21. Brohan P, Kennedy JJ, Harris I, Tett SFB, Jones PD (2006). Uncertainty estimates in regional and global temperature changes: a new data set from 1850. J of Geophys Res 111 p. D21206 10.1029/2005JD006548.

22. Bruckner AW, Bruckner RJ (1997). The persistence of black band disease in Jamaica: Impact on community structure. Proc $8^{\text {th }}$ Int Coral Reef Symp 1: 601-606.

23. Bruckner AW, Bruckner RJ, Williams EH (1997). Spread of a black band disease epizootic through the coral reef ecosystem in St. Ann's Bay, Jamaica. Bull of Mar Sci 61(3): 919-928. 
24. Bruno JF, Selig ER, Casey KS, Page CA, Willis BL, Harvell CD, Sweatman H, Melendy AM (2007). Thermal stress and coral cover as drivers of disease outbreaks. Plos Biol 5(6): 1220-1227.

25. Buchan A, Gonzalez JM, Moran MA (2005). Overview of the marine Roseobacter lineage. Appl Envir Microbiol 71: 5665-5677.

26. Burnett WJ, McKenzie JD (1997). Subcuticular bacteria from the brittle star Ophiactis balli represent a new lineage of extracellular marine symbionts in the a subdivision of the class Proteobacteria. Appl Environ Microbiol 63: 1721-1724.

27. Carlton RG, Richardson LL (1995). Oxygen and sulfide dynamics in a horizontally migrating cyanobacterial mat: black band disease of corals. FEMS Microbio Eco 18: 155-162.

28. Casamata D, Stanić D, Gantar M, Richardson LL (2011). Characterization of Roseofilum reptotaenium (Oscillatoriales, Cyanobacteria) gen. et sp. nov. isolated from Caribbean black band disease. $J$ of Phyco.

29. Cervino JM, Hayes RL, Goreau TJ, Smith GW (2004). Zooxanthellae regulation in yellow blotch/band and other coral diseases contrasted with temperature related bleaching: in situ destruction vs. expulsion. Symbiosis 37: 63-85.

30. Coffroth MA, Lasker HR, Oliver JK (1990). Coral mortality outside of the eastern Pacific during 1982-1983: relationship to El Niño. In: Glynn PW (ed) Global ecological consequences of the 1982-83 El Niño-Southern Oscillation. Elsevier.

31. Cohen Y, Jørgensen BB, Revsbech NP, Poplawski R (1986). Adaptation to hydrogen sulfide of oxygenic and anoxygenic photosynthesis among cyanobacteria. Appl Environ Microbiol 51(2): 398-407.

32. Cooney R, Pantos M, Le Tissier M, Rarer A, O'Donnell A, Bythell J (2002). Characterization of the bacterial consortium associated with black band disease in coral using molecular microbiological techniques. Environ Microbiol 4: 401-413.

33. Costerton JW, Stewart PS, Greenberg EP (1999). Bacterial biofilms: a common cause of persistent infections. Science 284: 1318-1322.

34. Decho AW, Norman RS, Visscher PT (2010). Quorum sensing in natural environments: emerging views from microbial mats. Trends in Microbiol 18(2): 73-80. 
35. Deser C, Phillips AS, Alexander MA (2010). Twentieth century tropical sea surface temperature trends revisited. Geophys Res Lett 37: L10701, doi:10.1029/2010GL043321.

36. Dinsdale EA (1994). Coral disease on the Great Barrier Reef. Joint scientific conference on science, management, and sustainability of marine habitats in the $21^{\text {st }}$ century. Abstract.

37. Douglas AE (2003). Coral bleaching - how and why? Mar Pol Bull 46(4): 385-392.

38. Ducklow HW, Mitchell R (1979). Observations on naturally and artificially diseased tropical corals: A scanning electron microscope study. Microb Ecol 5: 215-223.

39. Dustan P (1977). Vitality of reef coral populations off Key Largo, Florida: recruitment and mortality. Environ Geol 2: 51-58.

40. Edmunds PJ (1991). Extent and effect of black band disease on a Caribbean reef. Coral Reefs 10(3): 161-165.

41. Epstein PR (2005). Climate change and human health. New England J of Med 353(14): 1433-1436.

42. Fitt WK, Brown BE, Warner ME, Dunne RP (2001). Coral bleaching: interpretation of thermal tolerance limits and thermal thresholds in corals. Coral reefs 20(1): 51-65.

43. Frias-Lopez JA, Zerkle L, Bonheyo GT, Fouke BW (2002). Partitioning of bacterial communities between seawater and healthy, black band diseased, and dead coral surfaces. Appl Environ Microbiol 68: 2214-2228.

44. Frias-Lopez JA, Bonheyo GT, Jin QS, Fouke BW (2003). Cyanobacteria associated with coral black band disease in Caribbean and Indo-Pacific reefs. Appl Environ Microbiol 69: 2409-2413.

45. Frias-Lopez JA, Klaus JS, Bonheyo GT, Fouke BW (2004). Bacterial community associated with black band disease in corals. Appl Environ Microbiol 70: 5955-5962.

46. Gantar M, Sekar R, Richardson LL (2009). Cyanotoxins from black band disease of corals and from other coral reef environments. Microb Ecol 58: 856-864. 
47. Garcia-Pichel F, Castenholz RW (1990). Comparative anoxygenic photosynthetic capacity in 7 strains of thermophilic cyanobacteria. Arch Microbiol 153: 344-351.

48. Garrett P, Ducklow H (1975). Coral disease in Bermuda. Nature 253: 349350.

49. Giovannoni SJ, Stingl U (2005). Molecular diversity and ecology of microbial plankton. Nature 437: 343-348.

50. Gladfelter WB, Gladfelter EH, Monahan RK, Ogden JC, Dill RF (1977). Environmental studies of Buck Island Reef National Monument, St. Croix, US Virgin Islands. Spec Rept Nat Park Serv US Dept Int, p 137.

51. Glynn PW (1991). Coral reef bleaching in the 1980's and possible connections with global warming. Trends in Eco and Evol 6(6): 175-179.

52. Gonzalez JM, Moran MA (1997). Numerical dominance of a group of bacteria in the alpha-subclass of the class Proteobacteria in coastal seawater. Appl Environ Microbiol 63: 4237-4242.

53. Green EP, Bruckner AW (2000). The significance of coral disease epizootiology for coral reef conservation. Biol Conser 96(3): 347-361.

54. Hansen J, Sato M, Reudy R, Lo K, Lea DW, Medina-Elizade M (2006). Global temperature change. PNAS 103(39): 14288-14293.

55. Harvell CD, Kim K, Quirolo C, Weir J, Smith GW (2001). Coral bleaching and disease: Contributors to 1998 mass mortality in Briareum asbestinum (Octocorallia, Gorgonacea). Hydrobiol 460: 97-104.

56. Harvell CD, Mitchell CE, Ward JR, Altizer S, Dobson AP, Ostfeld RS, Samuel MD (2002). Climate warming and disease risks for terrestrial and marine biota. Science 296(5576): 2158-2162.

57. Harvell CD, Jordán-Dahlgren E, Merkel S, Rosenberg E, Raymundo L, Smith GW, Weil E, Willis B (2007). Coral disease, environmental drivers, and the balance between coral and microbial associates. Oceano 20(1): 172-195.

58. Hoegh-Guldberg O (1999). Climate change, coral bleaching and the future of the world's coral reefs. Mar Freshwater Res 50: 839-866. 
59. Howarth RW, Hobbie JE (1982). The regulation of decomposition and heterotrophic microbial activity in salt marsh soils: a review. In: Kennedy VS (Eds.) Estuarine comparisons. Academic Press, New York, pp. 103127.

60. Jørgensen BB (1982). Ecology of the bacteria of the sulfur cycle with special reference to anoxic-oxic interface environments. Phil Trans R Soc Lond B Biol Sci 298: 548-561.

61. Kaczmarsky LT, Draud M, Williams EH (2005). Is there a relationship between proximity to sewage effluent and the prevalence coral disease? Car J Sci 41(1): 124-137.

62. Klaus JS, Frias-Lopez JA, Bonheyo GT, Heikoop JM, Fouke BW (2007). Bacterial communities inhabiting the healthy tissues of two Caribbean reef corals: interspecific and spatial variation. Coral Reefs 24: 129-137.

63. Klaus JS, Janse I, Fouke BW (2011). Coral black band disease microbial communities and genotypic variability of the dominant cyanobacteria. Bul Mar Sci. 87(4): 795-821.

64. Kuta KG, Richardson LL (1996). Abundance and distribution of black band disease on coral reefs in the northern Florida Keys. Coral Reefs 15: 219223.

65. Kuta KG, Richardson LL (2002). Ecological aspects of black band disease of corals: relationships between disease incidence and environmental factors. Coral Reefs 21: 393-398.

66. Kushmaro A, Loya Y, Fine M, Rosenberg E (1996). Bacterial infection and coral bleaching. Nature 380(6573): 396.

67. Kushmaro A, Rosenberg E, Fine M, Loya Y (1997). Bleaching of the coral Oculina patagonica by Vibrio AK-1. Mar Eco Prog Ser 147: 159-165.

68. Kushmaro A, Rosenberg E, Fine M, Ben-Haim y, Loya Y (1998). Effect of temperature on bleaching of the coral Oculina patagonica by Vibrio AK-1. Mar Eco Prog Ser 171: 131-137.

69. Lafay B, Ruimy R, Rausch de Traubenberg C, Breitmayer V, Gauthier MJ, Christen R (1995). Roseobacter algicola, a new marine bacterium isolated from the phycosphere of the toxin-producing dinoflagellate Prorocentrum lima. Int J Syst Bacteriol 45: 290-296. 
70. Le Campion-Alsumard T, Golubic S, Hutchings P (1995). Microbial endoliths in skeletons of live and dead corals: Porites lobata. Mar Eco Prog Ser 117: 149-157.

71. Lesser MP, Mazel CH, Gorbunov MY, Falkowski PG (2005). Discovery of symbiotic nitrogen-fixing cyanobacteria in corals. Science. 305: 5686: 997-1000.

72. Maloy AP, Ford SE, Karney RC, Boettcher KJ (2007). Roseovarius crassotreae, the etiological agent of juvenile oyster disease (now known as Roseovarius oyster disease), in Crassotreae virginica. Aquacul 269(14): 71-83.

73. Mitchelmore CL, Schwarz JA, Weis VM (2002). Development of symbiosis-specific genes as biomarkers for the early detection of cnidarian-algal symbiosis breakdown. Mar Environ Res 54(3-5): 345-349.

74. Myers JL, Richardson LL, Sekar R (2007). Molecular detection and ecological significance of the cyanobacteria Geitlerinema and Leptolyngbya in black band disease of corals. Appl and Environ Microbio 73: 5173-5182.

75. Nealson KH (1997). Sediment bacteria: Who's there, what are they doing, and what's new? Ann Rev of Earth and Plan Sci 25: 403-434.

76. O'Toole GA, Kaplan HB, Kolter R (2000). Biofilm formation as microbial development. Ann Rev Microbiol 54: 49-79.

77. Page C, Willis $B(2006)$. Distribution, host range, and large scale variability in black band disease prevalence on the Great Barrier Reef, Australia. Dis Aquat Org 69: 41-51.

78. Perry C (1998). Grain susceptibility to the effects of microboring: implication for the preservation of skeletal carbonates. Sedimentology 45 : 39-51.

79. Pommier T, Canbäck B, Riemann L, Boström KH, Simu K, Lundberg P, Tunlid A, Hagström A (2007). Global patterns of diversity and community structure in marine bacterioplankton. Mol Ecol 16(4): 867-880.

80. Porter JW, Lewis SK, Porter KG (1999). The effect of multiple stressors on the Florida Keys coral reef ecosystem: A landscape hypothesis and a physiological test. Limnol and Oceano 44(3): 941-949. 
81. Radtke G, Le Campion-Alsumard T, Golubic S (1997). Microbial assemblages involved in tropical coastal bioerosion: an Atlantic-Pacific comparison. Proc 8th Int Coral Reef Symp, Panama 2: 1825-1830.

82. Rasoulouniriana D, Siboni N, Ben-Dov E, Kramarsky-Winter E, Loya Y, Kushmaro A (2009). Pseudoscillatoria coralii gen. nov., sp. nov., a cyanobacterium associated with coral black band disease. Dis of Aquat Org 87: 91-96.

83. Richardson LL, Carlton R (1993). Behavioral and chemical aspects of black band disease of corals: an in situ field and laboratory study. Proc of the Amer Acad Underwater Sci, p. 107-116.

84. Richardson LL (1996a). Occurrence of the black band disease cyanobacterium on healthy corals of the Florida Keys. Bull of Mar Sci 61(2): 485-490.

85. Richardson LL (1996b). Horizontal and vertical migration patterns of Phormidium corallyticum and Beggiatoa spp. associated with black band disease of corals. Microb Ecol 32: 323-335.

86. Richardson LL, Kuta KG, Schnell S, Carlton R (1997). Ecology of the black band disease microbial consortium. Proc 8th Int Coral Reef Symp 1: 597600.

87. Richardson LL, Kuta KG (2003). Ecological physiology of the black band cyanobacterium Phormidium corallyticum. FEMS Microbiol Eco 43: 287298.

88. Richardson LL, Sekar R, Meyers JL, Gantar M, et al. (2007). The presence of the cyanobacterial toxin microcystin in black band disease of corals. FEMS Microbiol L 272(2): 182-187.

89. Richardson LL, Miller AW, Broderick E, Kaczmarsky L, Gantar M, Stanić $\mathrm{D}$, Sekar R (2009). Sulfide, microcystin, and the etiology of black band disease. Dis of Aquat Organ 87: 79-90.

90. Ritchie KB (2006). Regulation of microbial populations by coral surface mucus and mucus-associated bacteria. Mar Ecol Prog Ser 332: 1-14.

91. Rodriguez S, Croquer A (2008). Dynamics of black band disease in a Diploria strigosa population subjected to annual upwelling on the northeastern coast of Venezuela. Coral Reefs 27: 381-388. 
92. Rohwer F, Breitbart M, Jara J, Azam F, Knowlton N (2001). Diversity of bacteria associated with the Caribbean coral Montastraea franksi. Coral Reefs 20: 85-91.

93. Rohwer F, Segritan V, Azam F, Knowlton N (2002). Diversity and distribution of coral-associated bacteria. Mar Ecol Prog Ser 243: 1-10.

94. Rosenberg E, Koren O, Roshef L, Efrony R, Zilber-Rosenberg I (2007). The role of microorganisms in coral health, disease, and evolution. Nature Rev Microbiol 5: 355-362.

95. Rützler K, Santavy D (1983). The black band disease of Atlantic reef corals. I. Description of the cyanophyte pathogen. PSZNI: Mar Ecol 4: 301-319.

96. Rützler K, Santavy D, Antonius A (1983). The black band disease of Atlantic reef corals. III. Distribution, ecology and development. PSZNI: Mar Ecol 4: 329-358.

97. Sato Y, Willis BL, Bourne DG (2009a). Successional changes in bacterial communities during the development of black band disease on the reef coral, Montipora hispida. ISME J 1-12.

98. Sato Y, Bourne DG, Willis BL (2009b). Dynamics of seasonal outbreaks of black band disease in an assemblage of Montipora species at Pelorus Island (Great Barrier Reef, Australia). Proc of the Roy Soc B 276: 27952803.

99. Sato Y, Bourne DG, Willis BL (2011). Effects of temperature and light on the progression of black band disease on the reef coral, Montipora hispida. Coral Reefs 30: 753-761.

100. Sekar R, Mills DK, Remily ER, Voss JD, Richardson LL (2006). Microbial communities in the surface mucopolysaccharide layer and the black band microbial mat of black band diseased Siderastrea siderea. Appl Environ Microbiol 72: 5963-5973.

101. Sekar R, Kaczmarsky LT, Richardson LL (2008). Microbial community composition of black band disease on the coral host Siderastrea siderea from three regions of the wider Caribbean. Mar Ecol Prog Ser 362: 85-98.

102. Sekar R, Kaczmarsky LT, Richardson LL (2009). Effect of freezing on PCR amplification of 16S rRNA genes from microbes associated with black band disease of corals. Appl Environ Microbiol 75: 2581-2584. 
103. Selig ER, Harvell CD, Bruno JF, Willis BL, Page CA, Casey KS, Sweatman $\mathrm{H}$ (2006). Analyzing the relationship between ocean temperature anomalies and coral disease outbreaks at broad spatial scales. p. 111-128. In JT Phinney (ed.) Coral reefs and climate change: science and management. AGU books, Washington, D.C.

104. Shiba T (1991). Roseobacter litoralis and Roseobacter denitrificans, aerobic pink-pigmented bacteria which contain bacteriochlorophyll a. Syst Appl Microbiol 14: 140-145.

105. Skyring GW, Chambers LA (1976). Biological sulfate reduction in carbonate soils of a coral reef. Aust J Mar Freshwater Res 27: 595-602.

106. Stal LJ (1995). Physiological ecology of cyanobacteria in microbial mats and other communities. New Phytol 131: 1-32.

107. Sokolow S (2009). Effects of a changing climate on the dynamics of coral infectious disease: a review of the evidence. Dis Aquat Org 87: 5-18.

108. Stanić D (2010). Characterization of Oscillatoria spp. and their role in black band disease of corals. FIU electronic theses and dissertations, paper 243.

109. Stanić D, Oehrle S, Gantar M, Richardson LL (2011). Microcystin production and ecological physiology of Caribbean black band cyanobacteria. Environ Microbio 13(4): 900-910.

110. Sunagawa S, DeSantis TZ, Piceno YM, Brodie EL, DeSalvo MK, Voolstra CR, Weil E, Anderson GL, Medina M (2009). Bacterial diversity and white-plague disease-associated community changes in the Caribbean coral Montastraea faveolata. ISME J 3: 512-521.

111. Sussman M, Bourne DG, Willis BL (2006). A single cyanobacterial ribotype is associated with both red and black bands on diseased corals from Palau. Dis Aquat Org 69: 111-118.

112. Sutherland KP, Porter JW, Torres C (2004). Disease and immunity in Caribbean and Indo-Pacific zooxanthellate corals. Mar Ecol Prog Ser 266: 273-302.

113. Taylor DL (1983). The black band disease of Atlantic reef corals. II. Isolation, cultivation, and growth of Phormidium corallyticum. PSZNI: Mar Ecol 4: 320-328. 
114. Toren A, Landau L, Kushmaro A, Loya Y, Rosenberg E (1998). Effect of temperature on the adhesion of Vibrio AK-1 to Oculina patagonica and coral bleaching. Appl Environ Microbiol 64: 1379-1384.

115. Thompson FL, lida T, Swings J (2004). Biodiversity of Vibrios. Microbiol Mol Biol Rev 68: 403-431.

116. Tribollet A (2008). The boring microflora in modern coral reef ecosystems: a review of its roles. Current developments in bioerosion: 67-94.

117. Viehman TS, Mills DK, Meichel GW, Richardson, LL (2006). Culture and identification of Desulfovibrio spp. from black band disease of corals on reefs of Florida Keys and Dominica. Dis Aquat Organ 69: 119-127.

118. Voss J, Richardson LL (2006). Nutrient enrichment enhances black band disease progression in corals. Coral Reefs 25: 569-576.

119. Voss JD, Mills DK, Myers JL, Remily ER, Richardson LL (2007). Black band disease microbial community variation on corals in three regions of the wider Caribbean. Microb Ecol 54: 730-739.

120. Warner ME, Fitt WK, Schmidt GW (1999). Damage to the photosystem II in symbiotic dinoflagellates: A determinant of coral bleaching. PNAS 96(14): 8007-8012.

121. Weil E (2004). Coral reef diseases in the Wider Caribbean, p. 35-68. In E. Rosenberg and Y. Loya (ed.) Coral health and disease. Springer, Berlin.

122. Weil E, Smith GW, Gil-Agudelo DL (2006). Status and progress in coral reef disease research. Dis of Aquat Org 69: 33-40.

123. Williams EH, Bunkley-Williams L (1990). The world-wide coral reef bleaching cycle and other sources of coral mortality. Atoll Res Bull 335: 173.

124. Willis BL, Page CA, Dinsdale EA (2004). Coral disease on the Great Barrier Reef. p. 69-104. In E. Rosenberg and Y. Loya (ed.), Coral health and disease. Springer, Berlin. 


\section{Figure Legends}

Figure 1. Graphical outline of the model for the BBD infection cycle.

Figure 2. Segment 1 of the model depicting the drivers of coral disease.

Supporting evidence is clustered according to relevance to each other.

Bolded circles indicated evidence provided both by this dissertation and others.

Figure 3. Segment 2 of the model depicting the reservoirs of BBD pathogens. Supporting evidence is clustered according to relevance to each other.

Figure 4. Segment 3 of the model depicting the pathogenesis of BBD. Supporting evidence is clustered according to relevance to each other.

Figure 5. Segment 4 of the model depicting biofilm formation in BBD. Supporting evidence is clustered according to relevance to each other.

Figure 6 . Segment 5 of the model depicting the pathobiology of BBD. Supporting evidence is clustered according to relevance to each other.

Figure 7. Segment 6 of the model depicting post-infection. Supporting evidence is clustered according to relevance to each other. 
Figure 1.

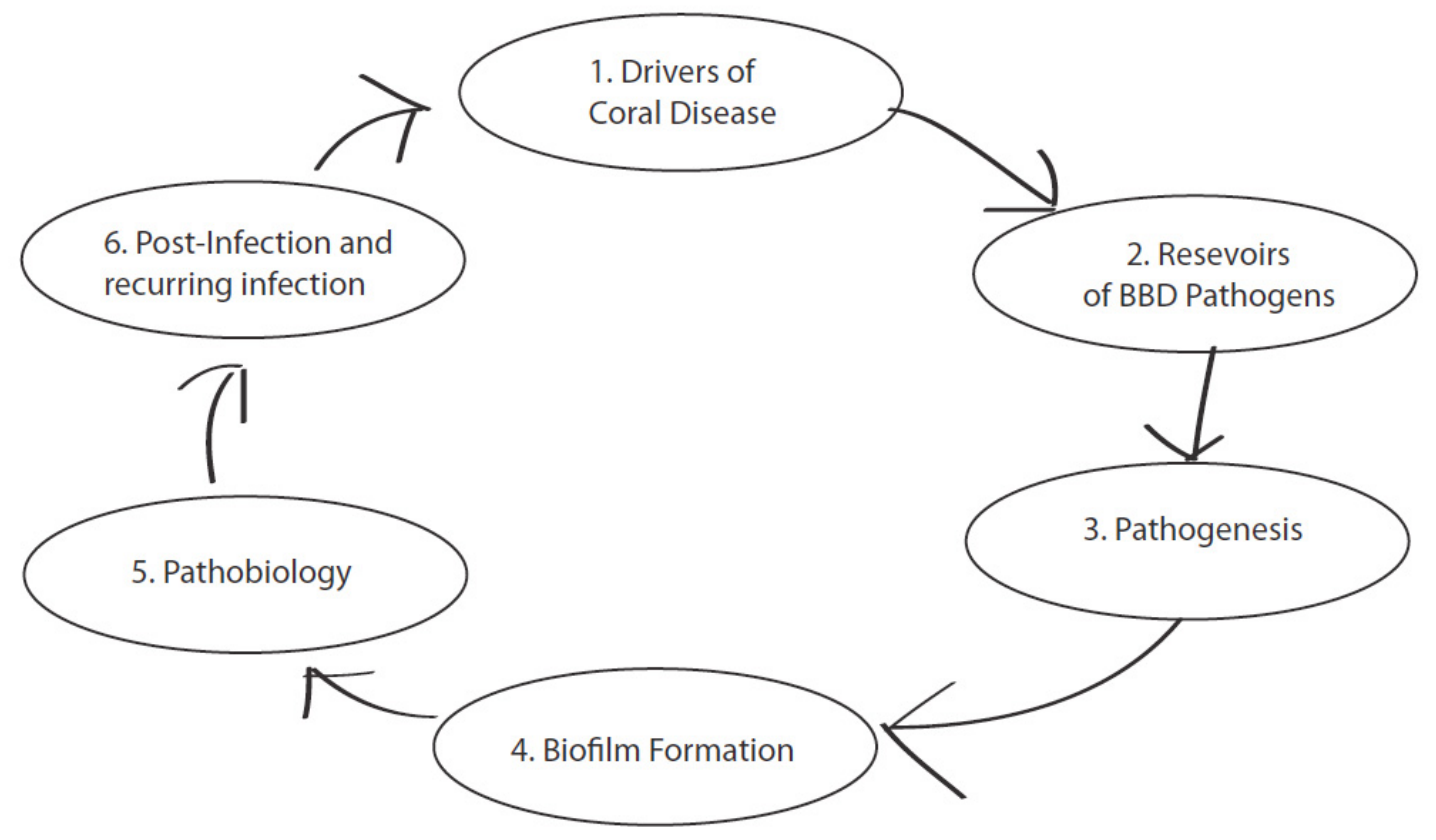


Figure 2.

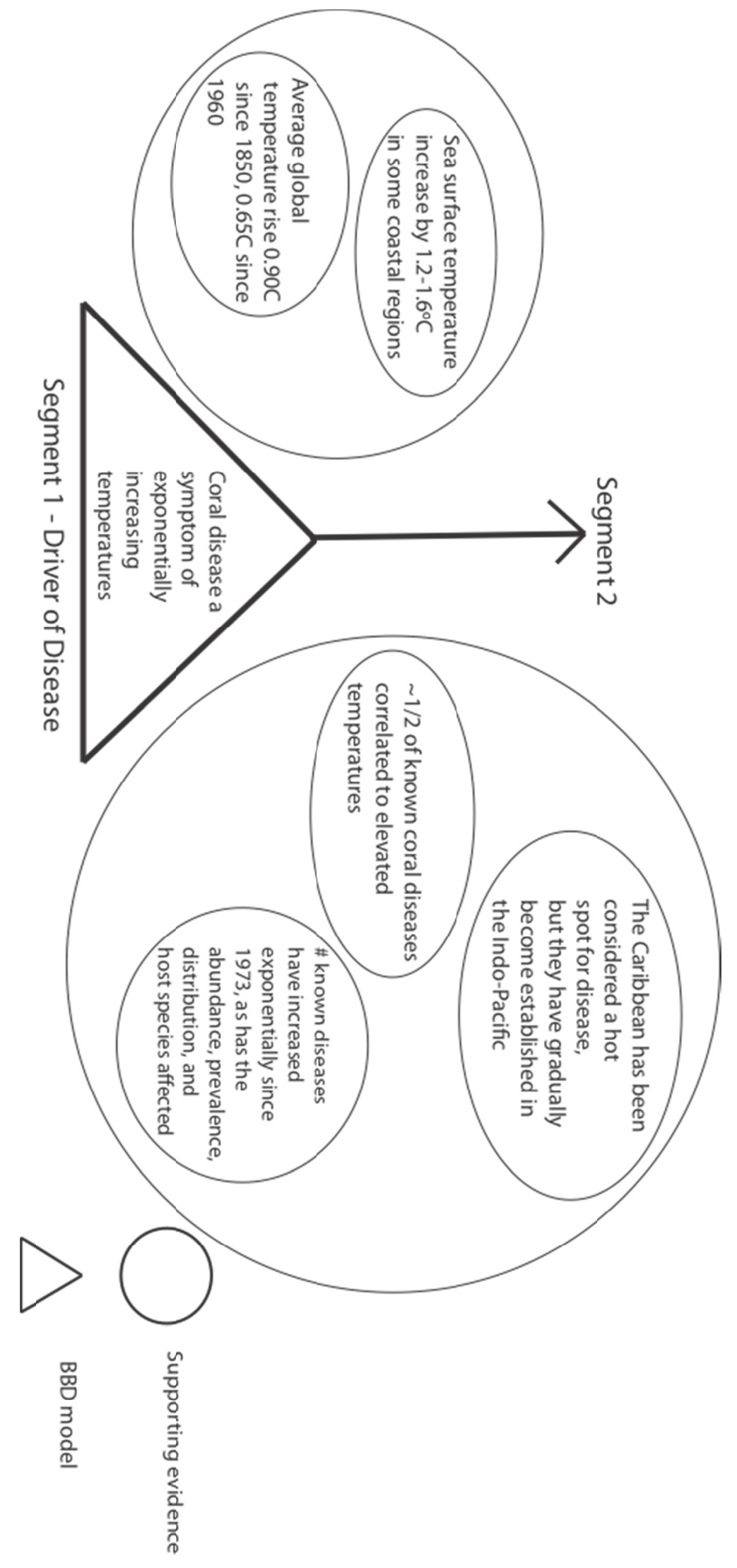


Figure 3.

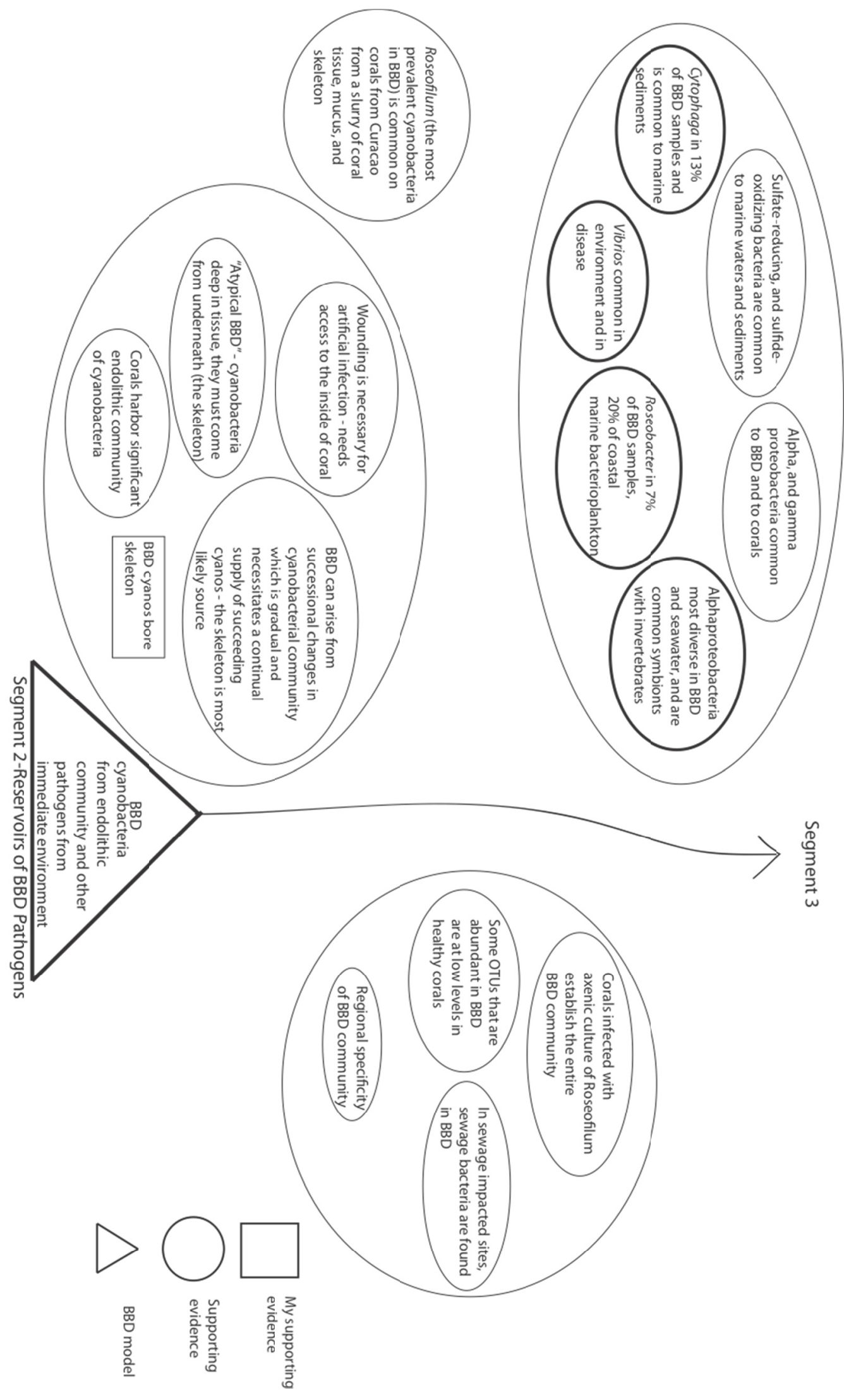


Figure 4.

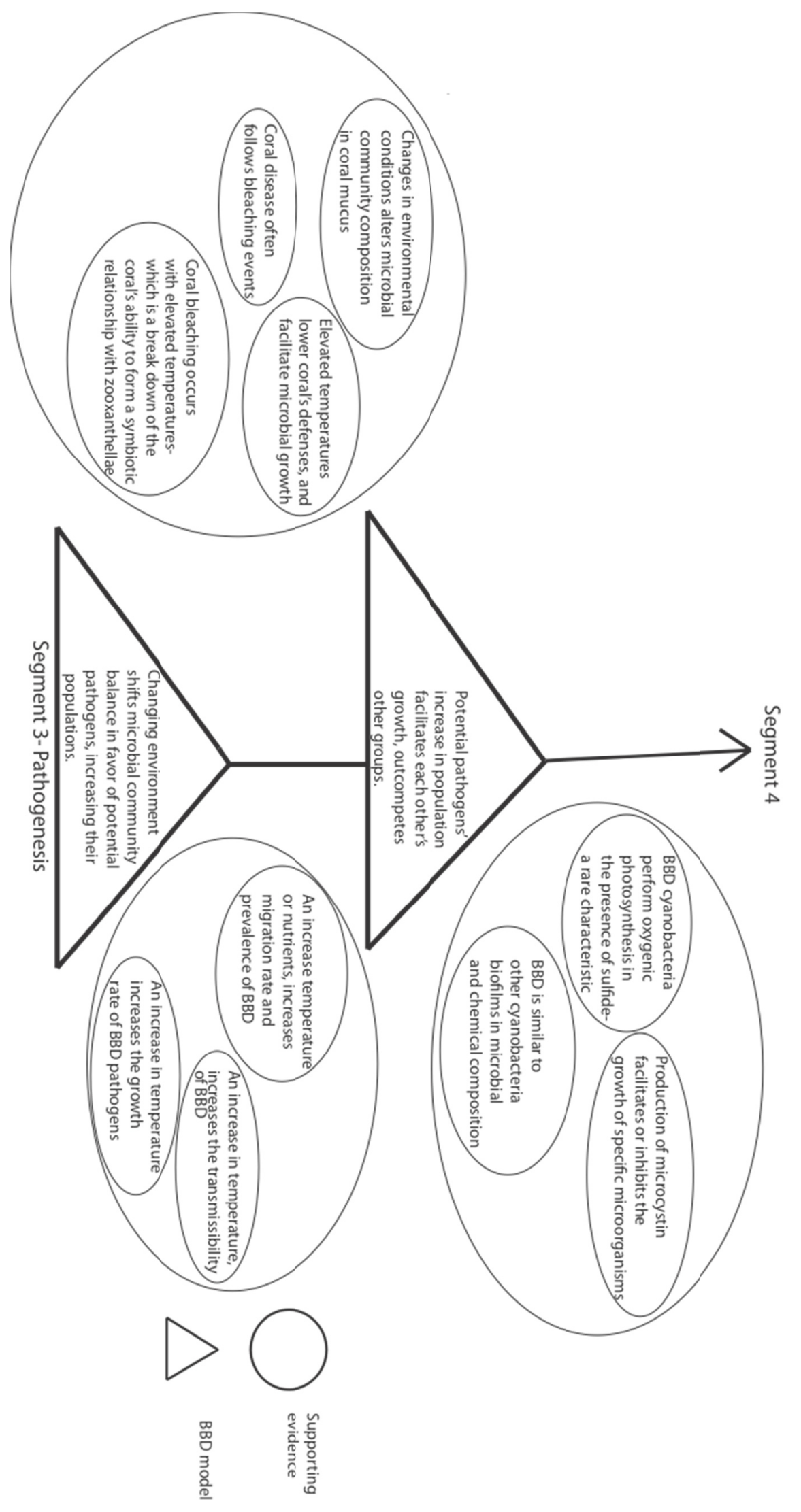


Figure 5.

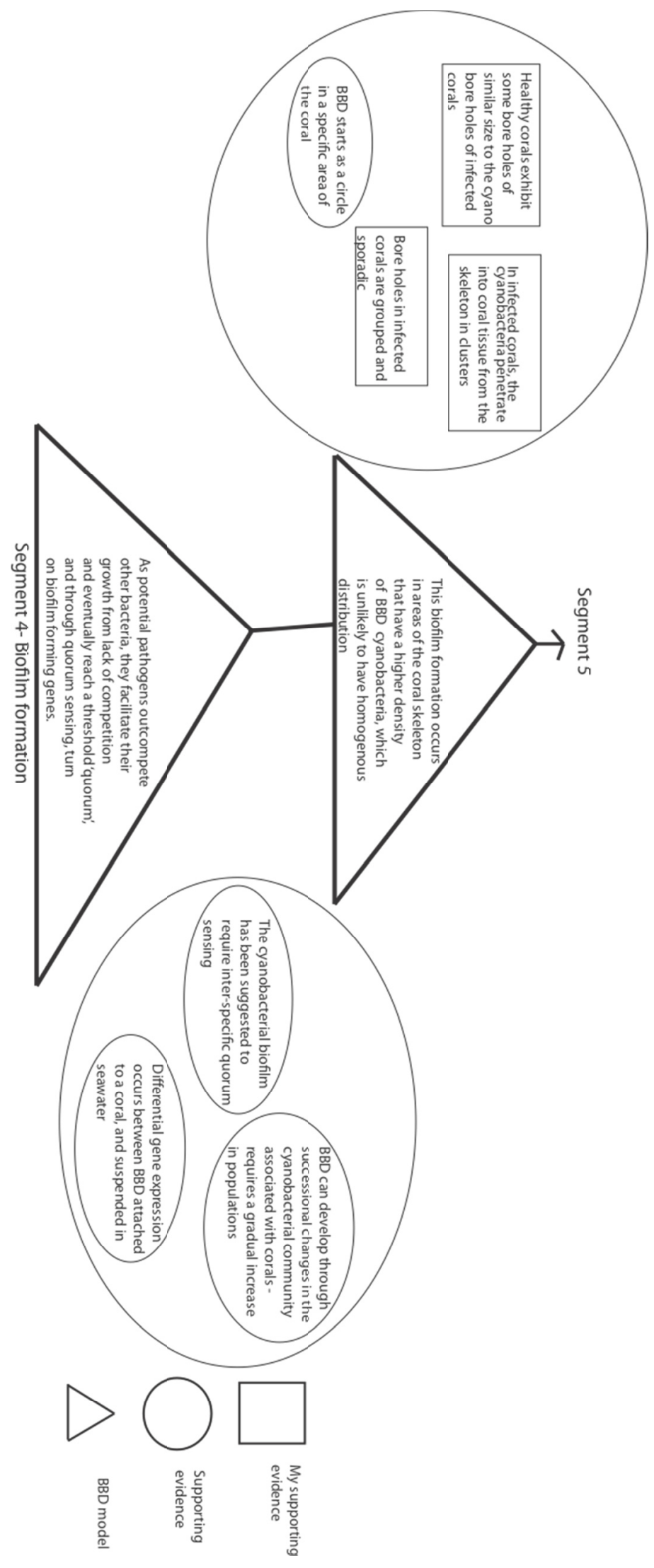


Figure 6.

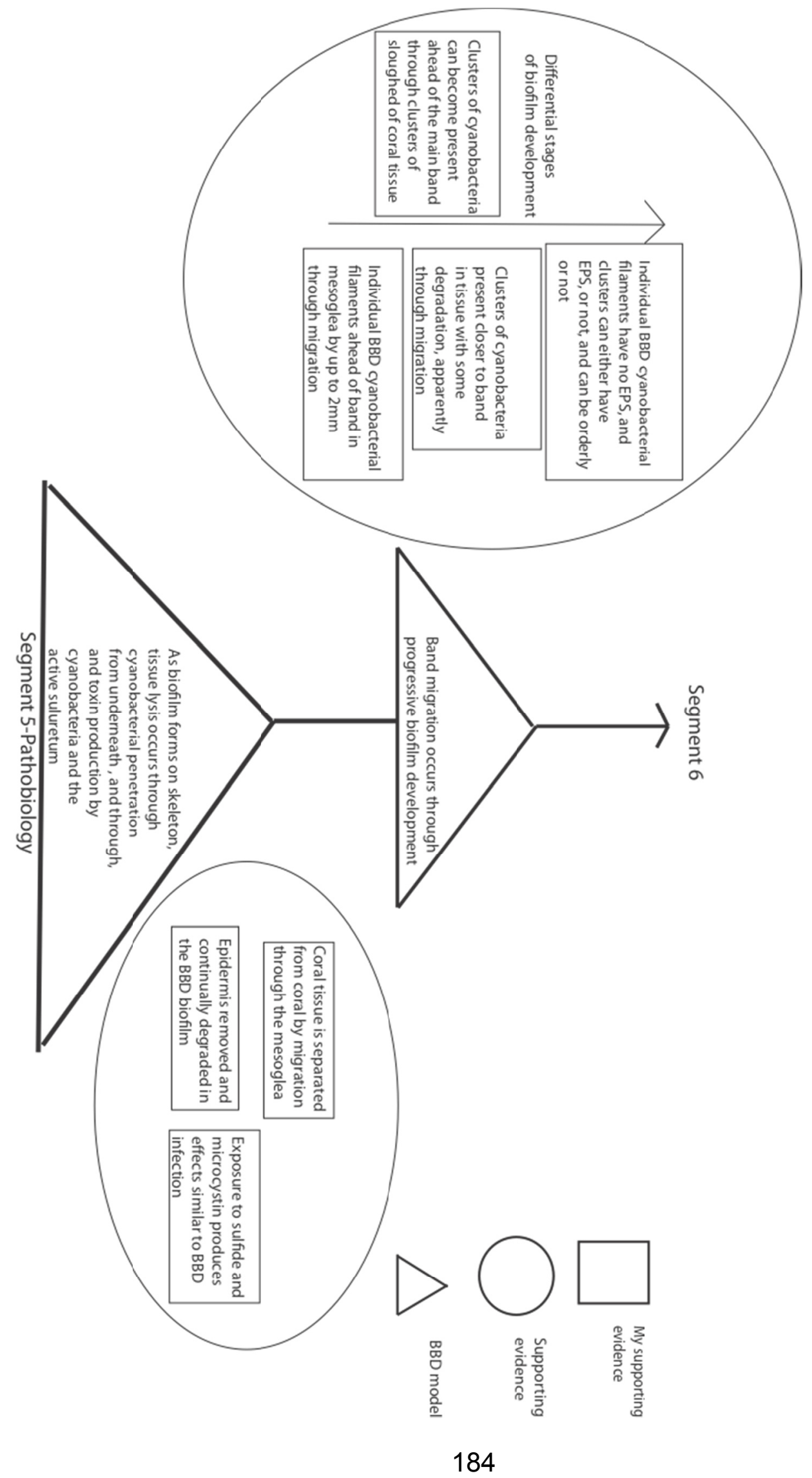


Figure 7.

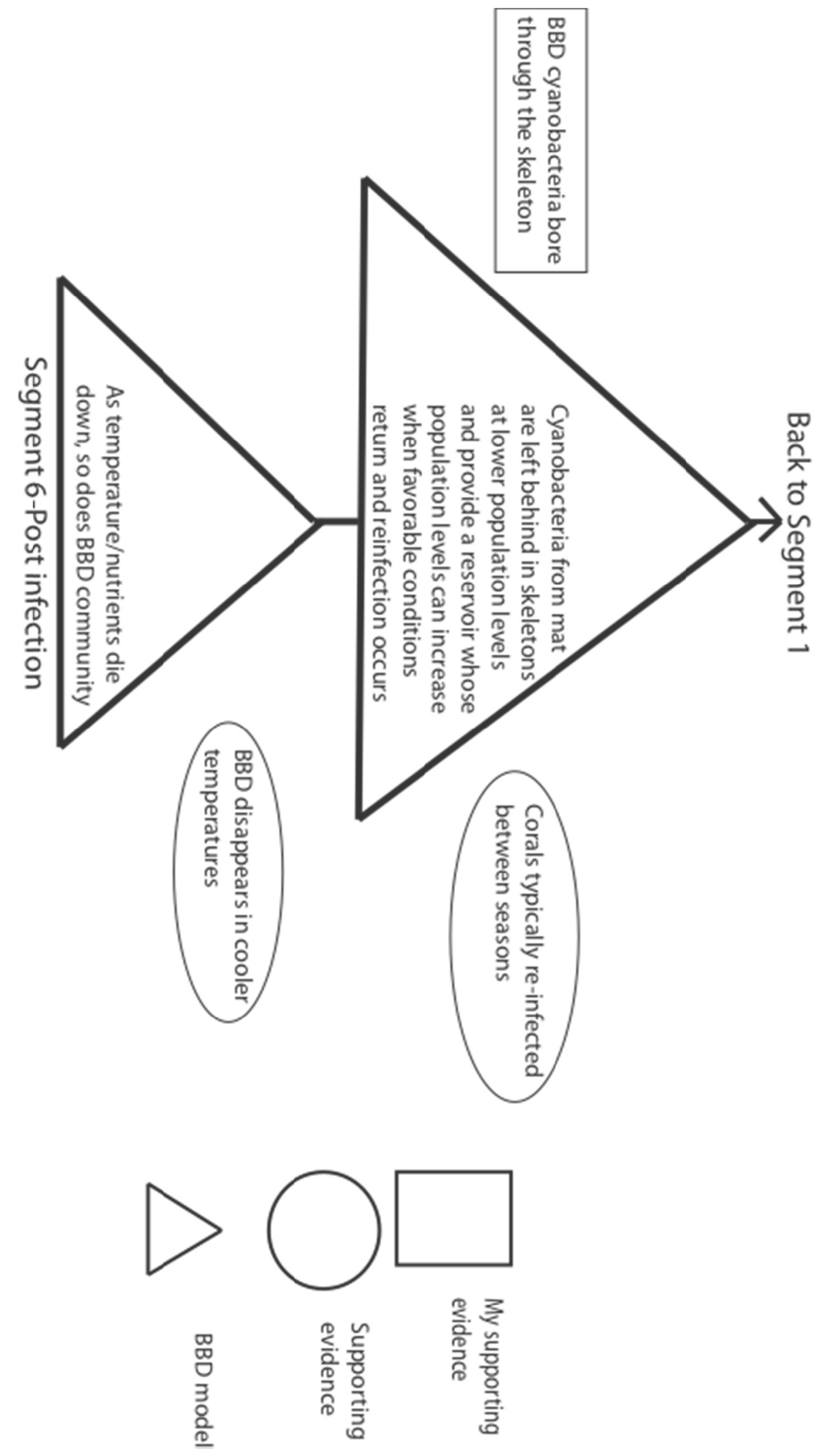


AARON W. MILLER - VITA

Email: aaron.miller@fiu.edu

Phone: 305-401-2449

Postgraduate

\section{UNIVERSITY EDUCATION}

2012 Degree: Ph.D. Biology

University: Biological Sciences, Florida International University Miami, FI

2006 Degree: M.S. Marine Biology

University: Oceanographic Center, Nova Southeastern University Davie, FI

\section{Undergraduate}

2004 Degree: B.S. Zoology

University: Evolution, Ecology, and Organismal Biology, The Ohio State University - Columbus, Oh (2000-2004)

\section{EMPLOYMENT}

FLORIDA INTERNATIONAL UNIVERSITY, Miami, FI

Teaching Assistant

- Microbiology

- Genetics

CALVIN, GIORDANO, AND ASSOCIATES, Fort Lauderdale, FI

EnvironmentalSpecialist

- $\quad$ Performed habitat assessments for wetlands

- $\quad$ Performed quarterly compliance monitoring on wetland sites

SCIENCE EYE, INC., Fort Lauderdale, FI

$2005-2006$

Field Instructor

- $\quad$ Led groups of students from $4^{\text {th }}-8^{\text {th }}$ grades on hands-on field trips to the Everglades

AMERICA COUNTS, Davie, FI

2004-2005

Math tutor

- $\quad$ Tutored kids from $3^{\text {rd }}-5^{\text {th }}$ grades in math

MUSEUM OF BIOLOGICAL DIVERSITY

2002-2004

Student Research Assistant

- $\quad$ Performed data entry, and collection management for the largest

freshwater mollusk collection in the world 


\section{AWARDS AND HONORS}

2012 FIU Dissertation Year Fellowship - awarded \$25,000 over one year to write dissertation entitled "Black band disease - elucidating disease mechanisms and origins" (2011-2012).

2009 FIU Minority Biomedical Research Support summer grant (\$300 awarded for research, Summer 2009).

2011 Awarded the Lucy and Bert award for best oral presentation at the $35^{\text {th }}$ scientific meeting of the Association of Marine Laboratories of the Caribbean.

2010 Awarded $3^{\text {rd }}$ place for oral presentation at the Florida Branch of the American Society for Microbiology conference.

Reviewer of Manuscripts: Microbial Ecology, FEMS Microbiology Ecology

\section{PEER-REVIEWED PUBLICATIONS}

Miller AW, Blackwelder P, Al-Sayegh H, Richardson LL (2012). Insights into migration and development of coral black band disease based on fine-structure analysis. Revista de Biologia Tropical 60(1): 21-27.

Gantar M, Kaczmarsky LT, Stanić D, Miller AW, Richardson LL (2011).

Antibacterial activity of marine and black band disease cyanobacteria against coral-associated bacteria. Marine Drugs 9(10): 2089-2105.

Miller AW, Richardson LL (2011). Fine-structure analysis of black band disease infected coral and coral exposed to the BBD toxins microcystin and sulfide. Journal of Invertebrate Pathology 109(1): 27-33.

Miller AW, Blackwelder P, Al-Sayegh H, Richardson LL (2011). Ultrastructural characterization of black band disease infecting corals of the Montastraea annularis spp. complex. Diseases of Aquatic Organisms 93: 179-190.

Miller AW, Richardson LL (2011). A meta-analysis of 16S rRNA gene clone libraries from the polymicrobial black band disease of corals. FEMS Microbiology Ecology 75(2): 231-241.

Richardson LL, Miller AW, Broderick E, Kaczmarsky L, Gantar M, Staniç D, Sekar R (2009). Sulfide, microcystin, and the etiology of black band disease. Diseases of Aquatic Organisms. 87:79-90. 